UNIVERSIDADE DE SÃO PAULO

FACULDADE DE FILOSOFIA, LETRAS E CIÊNCIAS HUMANAS

DEPARTAMENTO DE FILOSOFIA

PROGRAMA DE PÓS-GRADUAÇÃO EM FILOSOFIA

\title{
CRÍTICA E ONTOLOGIA NA FILOSOFIA DE BERGSON
}

Maria Adriana Camargo Cappello

Tese apresentada ao Programa de Pós-Graduação em Filosofia, da Faculdade de Filosofia, Letras e Ciências Humanas da Universidade de São Paulo, para obtenção do título de Doutor em Filosofia.

Orientador: Prof. Dr. Franklin Leopoldo e Silva 


\section{RESUMO}

Levando em conta as possibilidades de abordagem do pensamento de Bergson a partir de Matière et Mémoire - Essai sur la relation du corps à l'esprit, nos propomos, ao percorrer a análise da percepção e de suas conseqüências metafísicas, a tratar da relação entre o método bergsoniano e a ontologia dele resultante, o que implica uma crítica aos pressupostos do intelectualismo e, nesse sentido, uma nova concepção de Ser e de conhecimento.

\section{ABSTRACT}

Considering the possibilities of approache of Bergson's philosophy from Matière et Mémoire - Essai sur la Relation du Corp à L'esprit, we intend to treat of the relation between his method and the onthology that arises from it, as we peruse his analysis of perception and it's metaphysical consequences. That implies a certain critic of the presuppositions of the intellectualism and, in this sense, a new conception, of Being and knowledge.

\section{PALAVRAS-CHAVE/KEY WORDS}

representação, percepção, matéria, espírito, duração

representation, perception, mind, matter, duration 


\section{ÍNDICE}

INTRODUÇÃO

um método 1

a experiência da duração 3

dados imediatos da consciência $r$

consciência e mundo exterior $\quad 14$

“as imagens de mundo" 19

$\begin{array}{ll}\text { PERCEPÇÃO E REPRESENTAÇÃO } & 30\end{array}$

imagens $\quad 35$

campo de imagens : determinação e indeterminação 47

o corpo próprio $\quad 75$

percepção como recorte $\quad 88$

“dedução da consciência” 104

percepção e afecção 113

percepção e lembrança 127

DIÁLOGO ENTRE AUTORES 137

$\begin{array}{lr}\text { campo de imagens / idéias-coisas } & 137\end{array}$

Hilas e Filonous $\quad 149$

Berkeley e Bergson 156

DA ANÁLISE DA PERCEPÇÃo À METAFÍSICA DA MATÉRIA 168

relação do corpo com o espírito $\quad 168$

sobre o ponto de vista da consciência 189

a crítica à precedência do nada - o ser como duração 197

a crítica à pré-existência do possível — o ser como evolução

a intuição do real

225

BIBLIOGRAFIA 


\section{AgRADECIMENTOS}

Agradeço à Profa. Dr. Débora Morato Pinto e ao Prof. Dr. Luiz Henrique Lopes dos Santos pela leitura de parte deste trabalho e pelas valiosas observações relativas ao seu desenvolvimento, por ocasião do exame de qualificação.

Agradeço ao Prof. Dr. Franklin Leopoldo e Silva pela possibilidade de desenvolver esta pesquisa com o seu apoio e orientação.

Agradeço aos alunos do curso de Filosofia Contemporânea I, do $2^{\circ}$ semestre de 2005, da UFPr, com os quais pude testar algumas das hipóteses aqui apresentadas.

Este trabalho contou com o apoio do CNPq - Conselho Nacional de Desenvolvimento Científico e Tecnológico 
A Eugênio, Cândida e Aurora 


\section{INTRODUÇÃO}

um método

Bergson nos oferece, no último parágrafo da Introdução ao Pensamento $e o$ Movente $^{1}$, um resumo da evolução de seu pensamento que ele acabara de descrever. Ali, ele situa o início dessa evolução no âmbito daquilo que denomina como pseudo-filosofia, a partir do qual a consideração da seqüência de suas obras vai nos apresentar a descoberta de um método de investigação e a crescente ampliação do campo de aplicação desse método, cujas conclusões alimentam-se mutuamente. Assim, a aplicação do método - que se caracteriza essencialmente por uma rejeição de soluções que ele considera apenas verbais e que "requer do espírito, para cada novo problema, um esforço totalmente novo" — se daria, uma primeira vez, no Ensaio sobre os dados imediatos da consciência, ${ }^{2}$ campo de observação do espírito que se volta para si mesmo e descobre a duração; se ampliaria em Matéria e Memória, ${ }^{3}$ abarcando então a atividade do espírito em relação aquilo que não é ele próprio, por meio do que Bergson apresenta sua hipótese que delimita, por um lado, a função da inteligência na apreensão da matéria e, por outro, propõe a intuição como apreensão do espírito; e seguiria até Evolução criadora, ${ }^{4}$ com a inserção da peculiaridade humana no processo de evolução da vida em sua totalidade.

Colocando-nos, então, na origem desse processo, podemos identificar aquela que retroativamente Bergson denominará como pseudo-filosofia, tanto no evolucionismo de

\footnotetext{
${ }^{1}$ Bergson, H. La Pensée et le Mouvant. Paris, PUF, 1950.

${ }^{2}$ Bergson, H. Essai sur les données immédiates de la conscience. Paris, Quadrige/PUF, 1997.

${ }^{3}$ Bergson, H. Matière et Mémoire. Paris, Quadrige/PUF, 1999.

${ }^{4}$ Bergson, H. L'Évolution Créatrice. Paris, PUF, 1948.
} 
Spencer, seu contemporâneo do qual ele confessadamente foi um entusiasta, quanto no pensamento de Aristóteles, objeto de uma tese sua sobre a noção de lugar — Quid Aristóteles de Loco Senserit - apresentada, em 1888, como complemento à tese do Ensaio.

O que, no entanto, o evolucionismo de Spencer teria de comparável à física de Aristóteles? Sob o ponto de vista de Bergson, ao menos aquilo que seria o alvo de sua crítica endereçada a toda a tradição da filosofia ocidental, e que se aplicaria, portanto, a Spencer e a Aristóteles, uma vez que ambos seriam exemplos de um pensamento que, respectivamente, no âmbito da física clássica e no âmbito das concepções físicomatemáticas presentes em uma teoria que tematiza a evolução, não dariam conta da realidade pressuposta por cada uma delas, a saber, o tempo real, ou, como quer Bergson, a duração. A primeira, porque estaria ainda bastante dominada pelos "conceitos usuais transmitidos pelas palavras", 5 que espacializam a realidade em esquemas requisitados pela prática e necessários para a socialização. A segunda porque, ao interpretar a realidade, nela incluída tanto a vida em evolução quanto a consciência humana, com os instrumentos disponibilizados pela matemática, também só poderia tratar de simultaneidades exteriores umas às outras, ou seja, só poderia se manter sustentando uma espacialização, ainda que, se assim podemos dizer, de forma mais especializada.

a experiência da duração

Nesse sentido, não parece ser casual encontrarmos a primeira sistematização dessa crítica à espacialização do tempo, presentes em sua tese sobre a física de Aristóteles, como

\footnotetext{
${ }^{5}$ Bergson, H. 1950, p. 44-45.
} 
complemento à apresentação das primeiras conclusões positivas a que Bergson chegou a partir dessa crítica, no Ensaio. A ligação, como o próprio Bergson frisa, entre a crítica ao pensamento filosófico — citamos aqui Aristóteles e Spencer, como poderíamos citar Kant, ou mesmo Descartes — e o início de seu próprio progresso no conhecimento, é direta ou, se preferirmos, mediada apenas por um método que se constitui, justamente, como uma proposta de reflexão sobre as realidades a serem conhecidas, que evite os erros detectados nas reflexões anteriores pela preeminência dos conceitos que impedem uma abordagem precisa daquilo que se quer conhecer: "Nossa iniciação no verdadeiro método filosófico data do dia em que rejeitamos as soluções verbais, tendo encontrado na vida interior um primeiro campo de experiência."6

Mas rejeitar soluções verbais e partir da observação estrita do que ocorre em um campo experimental não são regras caras aos autores que, de modo geral, poderiam ser incluídos na grande vertente do "empirismo", como Aristóteles e Spencer, se mais uma vez quisermos nos valer de nossos exemplos? Será preciso então que Bergson explicite de que modo o simples uso das palavras já se mostra como uma imposição de conceitos, e como a investigação da experiência pode ganhar a precisão que ele preconiza.

Sem pretender analisar o método proposto por Bergson, notemos apenas que, à preeminência dos conceitos sobre a experiência, na explicação filosófica da realidade, o método bergsoniano propõe, por oposição, a adesão estrita à experiência da realidade. À generalidade dos conceitos, ou das palavras, utilizados pela filosofia — "os sistemas filosóficos não são talhados na medida da realidade em que vivemos. Eles são muito amplos para ela." ${ }^{7}$ — Bergson propõe a precisão reveladora de uma compreensão dessa realidade tão estreitamente ligada a ela que a impossibilidade da interposição de qualquer outra

\footnotetext{
${ }^{6}$ Bergson, H. 1950, p. 98

${ }^{7}$ Bergson, H. 1950, p. 1.
} 
explicação entre tal compreensão e o objeto compreendido seria a prova mesma de sua veracidade - "a explicação que devemos julgar satisfatória é a que adere ao objeto: nenhum vazio entre eles, nenhum interstício no qual uma outra explicação também pudesse se alojar; ela só convém a ele, ele só se presta a ela.",

O que se explicita quando, por meio dessa adesão precisa ao campo de experiência constituído pela consciência, Bergson encontra a realidade do tempo; tempo sobre o qual a antiguidade clássica discorria usando os termos da linguagem usual e o qual a ciência moderna media sem jamais alcançar, ele que sempre teria estado à mão naquilo que vivenciamos: "Mas essa duração, que a ciência elimina, que é difícil de conceber e exprimir, nós a sentimos e vivemos."9

Não nos será possível acompanhar a gênese do pensamento de Bergson, ainda que o esquema por ele apresentado nos deixe tentado a fazê-lo. Pois, como saber se a intuição da realidade da consciência, eminentemente duração, foi o que levou Bergson a sustentar que a compreensão dessa consciência como um conjunto de estados sucessivos, calcada em uma concepção equivocada do tempo, era o resultado da imprecisão de sua abordagem pela imposição de esquemas cabíveis à exploração de outros campos de experiência? Ou se, ao contrário, foi uma adesão explícita a um empirismo estrito que o levou, ao se liberar de qualquer pressuposição na observação da experiência, à "visão direta" da duração nessa experiência então purificada?

Se, portanto, não é possível decidir sobra a primazia do método ou da primeira intuição, por outro lado, é possível rastrear o caminho percorrido até que método e intuição tenham vindo à tona.

Senão, vejamos.

\footnotetext{
${ }^{8}$ Bergson, H. 1950, p. 1-2.

${ }^{9}$ Bergson, H. 1950, p. 4.
} 
Bergson, apesar de entusiasta da filosofia da vida, de Spencer, reconhece "a fragilidade dos Primeiros Princípios $" 10$ e, de início, diz ter reputado tal fragilidade ao fato de o autor não ter podido "aprofundar as 'idéias últimas' da mecânica". Com efeito, a noção de força exerce um papel central nas explicações de Spencer sobre a natureza do tempo, do espaço, do movimento e da matéria para a qual todas estas convergiriam. ${ }^{11}$ Nesse contexto, a idéia do tempo — primordial para uma filosofia que tem como objeto central o movimento, a transformação, a evolução da vida - necessariamente teria de chamar a atenção de Bergson. E a idéia de tempo, nos Primeiros Princípios, se apresenta como a abstração de um dos dois tipos de relações estabelecidas pela consciência, a saber, as relações de sucessão — o espaço seria, seguindo o mesmo raciocínio, uma abstração feita a partir das relações de co-existência. Insatisfeito com as hipóteses construídas por Spencer, especialmente sobre a noção de tempo que não lhe parecia fazer jus a um evolucionismo, e ao procurar saídas aprofundando-se nessas questões, Bergson acabaria concluindo que seria a própria mecânica, e não apenas aquilo que dela ele encontrou em Spencer, que não alcançaria a natureza do tempo. E é ele quem nos explica.

"Sabemos muito bem, desde os tempos de colégio, que a duração se mede pela trajetória de um móvel e que o tempo matemático é uma linha; mas do que não nos demos conta foi de que essa operação se distingue radicalmente de todas as outras operações de medição, pois ela não se desenvolve sobre um aspecto ou um efeito representativo daquilo que se quer medir, mas sobre algo que o exclui. A linha que medimos é imóvel, o tempo é móvel. A linha está feita, o tempo é o que se faz e, mesmo, é o que faz com que tudo se faça.",12

\footnotetext{
${ }_{10}^{10}$ Bergson, H. 1950, p.2.

${ }^{11}$ Cf. Spencer, H. First Principles, cap. 3.

${ }^{12}$ Bergson, H. 1950, p. 3.
} 
Se, com efeito, explicamos o tempo pela sucessão, se "sua essência é passar”, quando o quisermos medir teremos necessariamente de espacializá-lo e, portanto, perdê-lo. É assim que a mecânica não alcança o tempo, pois se volta para a investigação dessa realidade armada com as ferramentas da medição. E o que é necessário para medir? Que haja unidades que possam se adicionar umas às outras indefinidamente. No entanto, se a natureza mesma do tempo é passar, essa adição fica inviabilizada, "nenhuma de suas partes está mais lá quando a outra se apresenta". ${ }^{13}$ O que faz então a mecânica? Representa o tempo por uma linha, na qual cada ponto seria a representação de um instante, e mede a passagem do tempo pela trajetória de um móvel na sucessão de cada um desses instantes. No entanto, ao agir assim, já renunciou ao tempo real, medindo apenas o tempo que ela espacializou justamente para poder medir.

"Jamais a medição do tempo disse respeito à duração enquanto duração; contamos apenas um certo número de extremidades, de intervalos, ou de momentos, ou seja, nada mais do que paralisações virtuais do tempo. Estabelecer que um acontecimento se produzirá ao final de um tempo $t$, é simplesmente dizer que teremos contado, daqui até lá, com um número $t$ de simultaneidades de um certo gênero. Entre as simultaneidades se passará o que quisermos. O tempo poderá se acelerar enormemente, e mesmo, infinitamente: nada mudará para o matemático, para o físico, para o astrônomo. Profunda será, no entanto, a diferença aos olhos da consciência (...)." Nada mudará para aquele que mede, mas sim para aquele que vive o tempo. É somente na espera, que só pode ser vivida, que se dará, para além de qualquer instrumento de medição, a realidade do tempo. É, portanto, na consciência, que encontramos esta realidade (a realidade do tempo).

Novo campo de investigação se abre, então, para Bergson, na sua busca por uma interpretação adequada do tempo: o "domínio da vida interior". No entanto, desde Descartes

\footnotetext{
${ }^{13}$ Bergson, H. 1950, p. 2.
} 
até Spencer, e passando por Kant, se admite a relação estrita entre o tempo e a consciência. Para ficarmos no exemplo do qual Bergson parte, Spencer, tal relação, diretamente influenciada pelo kantismo, é explícita. Se, com efeito, para Kant, o tempo é a própria forma do sentido interno pelo qual intuímos os fenômenos interiores à nossa consciência, imediatamente, e os fenômenos exteriores, mediatamente, e, portanto, o tempo é pressuposto de qualquer experiência, eminentemente a da interioridade; para Spencer, o tempo remete a essa interioridade uma vez que ele é a abstração das mudanças concretas que ocorreriam na consciência, sob a forma da sucessão. Diante disso, por que, então, nunca, ao refletir sobre a consciência, a filosofia teria se deparado com a duração? Porque, segundo Bergson, ainda que o campo de observação tenha se transferido dos objetos da consciência para a própria consciência, os instrumentos de abordagem continuaram sendo aqueles adequados aos objetos, propícios à medição, instrumentos que, se não eram apropriados para alcançar a realidade do tempo quando estávamos voltados para a “exterioridade", também não o poderiam ser quando nos voltamos para "a interioridade". Manteve-se o registro do tempo espacializado da mecânica, espacializando agora a própria consciência por meio da concepção associacionista que a interpreta como uma justaposição de estados heterogêneos exteriores uns aos outros.

dados imediatos da consciência

E é justamente partindo dessa crítica à espacialização da consciência, por meio da quantificação de seus estados, que Bergson inicia sua reflexão sobre a experiência da interioridade, apresentada no Ensaio. 
É ali, ao observar os estados intensivos da consciência - sentimentos, esforços, sensações afetivas e representativas —, que Bergson localiza o equívoco no fato destes terem sido sempre considerados como grandezas extensivas, passíveis, portanto, de aumento ou diminuição pela adição ou subtração das porções homogêneas das quais seriam constituídos. No entanto, como Bergson se ocupará em explicitar, estas são características dos números, ou daquilo que se aplica adequadamente às coisas consideradas no espaço e que teriam sido indevidamente aplicadas aos estados da consciência, domínio mesmo da duração. Tal explicitação será realizada por meio de uma análise desses estados intensivos que então mostrará o caráter qualitativo de suas mudanças. Com efeito, os estados internos não se sucedem como os números, ou se tornam mais ou menos intensos por acréscimo ou subtração de unidades homogêneas, ao contrário, a alteração de sua intensidade revela ser uma transformação qualitativa, e uma ampliação ou restrição de sua abrangência.

A origem dessa espacialização indevida, Bergson finalmente reputa à atividade do entendimento, que então revela sua função eminentemente prática, ligada aos interesses de adaptação da espécie e que, nesse sentido, transporia hábitos adquiridos no tratamento da exterioridade para a observação da interioridade. Assim, pela transposição da atividade de unificação e simplificação exercida pelo entendimento em relação à exterioridade, agora, para a observação da interioridade, ou seja, pela transposição da grandeza das causas ou dos efeitos exteriores destes estados internos aos próprios estados, se escamotearia a multiplicidade qualitativa dos estados internos que seriam então interpretadas como alterações de grandeza. No entanto, é natural que não percebamos essa transposição, para nós, a simples confirmação de um hábito - e hábito adquirido pela espécie — e vivamos a ilusão de que estamos percebendo imediatamente nossos estados internos como passíveis de aumento e diminuição. De fato, essa "percepção" não seria imediata, mas o resultado da 
atividade da consciência reflexiva que nos teria levado, como afirma Bergson, a desenvolver “o hábito de colocar a causa no efeito e a substituir nossa impressão ingênua dessa experiência pelo que a experiência e a ciência nos ensinam." 14

No entanto, a quantificação dos estados de consciência, que se limita à consideração isolada de cada um deles, tem conseqüências mais graves quando considerada em relação à "série de nossos estados psicológicos, introduzindo o espaço em nossa concepção de duração". 15

Pois, uma vez quantificados, os estados da consciência ganham a impenetrabilidade própria ao número, formando, então, uma série também própria ao número, ou seja, que pressupõe um intervalo entre cada estado, intervalo que permanece e que, mais uma vez, possibilita sua mensuração.

Se, portanto, a inadequação anteriormente descrita dizia respeito à indistinção entre o extensivo e o intensivo e à conseqüente transposição de um para o domínio do outro, a inadequação agora diz respeito à não distinção entre a multiplicidade numérica e aquela própria dos estados afetivos da consciência; a primeira, multiplicidade de partes exteriores umas às outras que são percebidas simultaneamente; a segunda, multiplicidade de partes que se interpenetram num fluxo contínuo. Com efeito, esta se torna numérica justamente pela separação, neste fluxo, de partes, pela intromissão de um intervalo que permanece para, efetiva mente, estabelecer a idéia de sucessão onde o entendimento só veria o aparecimento e desaparecimento de novos estados/unidades que nada guardariam do anterior. Mas o que seriam esses intervalos, senão a idéia de um meio homogêneo subjacente aos momentos que passam? Um meio, portanto, que permanece e que, nesse sentido, já não poderia mais ser considerado tempo, mas, sim, espaço?

\footnotetext{
${ }^{14} \mathrm{Cf}$, Tiberghein, "Une source inconnue du bergsonisme”. In Hude, H. et alli, Bergson, Naissance d'une philosophie, actes du colloque de Clermont-Ferrand 17 et 18 novembre 1989, Paris, PUF, 1990.

${ }^{15}$ Bergson, H. 1997, p. 55.
} 
Com efeito, segundo a análise apresentada então por Bergson, o espaço é a concepção de um meio homogêneo, pelo intelecto humano, que, assim, reagiria contra a heterogeneidade que constitui o fundo de nossa experiência para melhor agir sobre ela operando distinções nítidas - que tornariam o homem, em última instância, capaz de contar, abstrair e criar a linguagem. Se o espaço é assim definido por Bergson como um meio homogêneo e, nesse sentido, sem distinções qualitativas, segue-se que todo meio homogêneo e indefinido é espaço, pois, uma vez que a homogeneidade consiste na ausência de qualquer qualidade, não é possível conceber como duas formas do homogêneo poderiam se distinguir uma da outra, ou como poderia haver duas formas homogêneas distintas. No entanto, adverte Bergson, acredita-se que o tempo seria o meio homogêneo preenchido pela sucessão, enquanto o espaço seria o meio homogêneo preenchido pela coexistência. Distinção que não se sustenta quando se observa que a sucessão, ao ser colocada em um meio homogêneo, se transforma em simultaneidade — "quando fazemos do tempo um meio homogêneo, no qual os estados de consciência parecem se desenrolar, o colocamos, por isso mesmo, de uma só vez, o que significa que o subtraímos da duração" — e que, ao contrário, confirma a suspeita de "se o tempo, concebido como um meio homogêneo, não seria um conceito bastardo originário da intrusão da idéia de espaço nos domínios da consciência pura."

Em resumo, é por estarmos habituados a deixar nosso intelecto operar as distinções que se mostraram profícuas em nossa ação no mundo, estruturando a multiplicidade deste sobre a forma de uma homogeneidade, que, aos nos voltarmos para a interioridade de nossa consciência, introduzimos aí essa forma de estruturação da experiência, e destacamos e posteriormente justapomos estados que então colocamos uns ao lado dos outros; projetando, dessa forma, "o tempo no espaço, expressamos a duração por meio da extensão, e a 
sucessão toma para nós a forma de uma linha contínua ou de uma cadeia, cujas partes se tocam sem se penetrar."

No entanto, se nos damos conta dessa operação que, de resto, é a transposição indevida da prática para a teoria, podemos evitá-la e, assim, ao evitar a projeção do espaço no tempo, encontrar, nessa forma especial de "sucessão" própria à nossa consciência, a própria realidade da consciência, que é a realidade do tempo, da duração pura.

Sendo assim, "a duração pura nada mais seria que uma sucessão de mudanças qualitativas que se fundem, que se penetram sem contorno preciso, sem nenhuma tendência a se exteriorizar umas em relação às outras, sem nenhum parentesco com o número: seria a pura heterogeneidade (...) a partir do momento em que atribuímos a menor homogeneidade que seja à duração, introduzimos sub-repticiamente o espaço."16

Negando-se, portanto, por um lado, a perder o tempo por apresentá-lo como uma sucessão de partes exteriores umas às outras que redundam em um infinito presente e, por outro lado, negando-se a perder o tempo por introduzir a simultaneidade dessas partes, ou seja, por espacializá-lo, Bergson propõe que encontremos o tempo na experiência de uma continuidade em transformação, "uma sucessão sem distinção, uma interpenetração, uma solidariedade, uma organização íntima de elementos, cada um dos quais, representativo do todo".

Fiquemos, então, à guisa de ilustração, com a aplicação, por Bergson, dessas três hipóteses ao próprio instrumento de medição do tempo: um relógio e suas oscilações. Se, com efeito, eu considerar as 60 oscilações do pêndulo de um relógio ao perfazer um minuto, poderei considerá-las a partir de três hipóteses: em uma $1^{\mathrm{a}}$ hipótese, poderei representar essas 60 oscilações de uma só vez, o que levaria a própria exclusão da idéia de sucessão; em uma $2^{\mathrm{a}}$ hipótese, poderei representar essas 60 oscilações sucessivamente, à maneira de sua

\footnotetext{
${ }^{16}$ Bergson, H. 1997, p.77.
} 
representação no espaço, pensarei, então, cada oscilação sem nada guardar da precedente, e estarei no presente eterno no qual, propriamente falando, não há sucessão ou duração; finalmente, como $3^{\mathrm{a}}$ hipótese, "se conservar, unida à imagem da oscilação presente, a lembrança da oscilação que a precedeu, das duas uma, ou justaporei duas imagens, e recairemos então em nossa primeira hipótese; ou perceberei uma dentro da outra, penetrando-se e organizando-se entre si como notas de uma melodia, formando o que costumamos chamar de multiplicidade indistinta ou qualitativa, sem nenhuma semelhança com o número; obterei, assim, a imagem de uma duração pura, mas também me verei completamente liberto da idéia de um meio homogêneo ou de uma quantidade mensurável."

consciência e " mundo exterior"

Considerando sua análise sobre os estados internos da consciência - mesmo sem levar em conta as conseqüências dessa análise em relação ao problema da liberdade —, e sua conclusão de que é um hábito do intelecto que se interpõe entre nossa vivência e nossa interpretação dessa vivência, e que nos leva a espacializar nossa concepção do tempo e nos impede de apreendê-lo como duração, Bergson tocou em pontos que o impulsionaram a ir além.

Em primeiro lugar, como havíamos notado acima, definiu-se e aplicou-se um método que prescreve, essencialmente, o despojamento de formas pré-concebidas de acesso à experiência e a busca, em cada campo de experiência, dos conceitos com os quais interpretá-la. E, em segundo lugar, os resultados da aplicação desse método apontam para duas outras convicções que, juntamente com este método, mostram-se essenciais ao seu 
pensamento: a realidade da duração, que, até aqui, ao menos, é a única a qual temos acesso imediato, uma vez que é a realidade de nossa própria consciência que se dá a nós diretamente; e a circunscrição da inteligência humana a um domínio da realidade ou a uma determinada função em relação a essa realidade.

Tomemos então essa crítica do entendimento a partir da qual foi possível apreender a realidade mesma da consciência. Ela aponta para uma circunscrição do entendimento ao domínio de nossa ação sobre as coisas, donde surgirá, tanto uma hipótese explicativa dessa ação, no seu próximo livro, Matéria e Memória, quanto a localização dessa forma determinada de ação no mundo, na evolução da vida, em Evolução Criadora - quando então Bergson poderá voltar a considerar o tema da evolução munido da concepção do tempo real que ele julgava necessária a uma teoria da evolução que se quisesse consistente.

Portanto, como seu próprio discurso adverte, antes de se voltar para o desenvolvimento desse ponto de vista ainda mais abrangente, que considera a evolução da vida como um todo e na qual o entendimento seria apenas uma parte, Bergson irá se dedicar a um estudo mais aprofundado da própria estrutura desse entendimento, pois, quanto melhor ele puder circunscrever o modo de ação do entendimento, melhor ele poderá sustentar a realidade daquilo que lhe escapa e que é julgado, pelo entendimento, justamente por isso, como irreal ou incompreensível. Assim, para sustentar sua hipótese mesma da duração, encontrada no campo de experiência interior à consciência, é preciso ampliar a abrangência dessa experiência, é preciso centrar a análise não mais procurando eliminar aqueles elementos que remeteriam à exterioridade da consciência, mas investigar como essa consciência se "relaciona com a exterioridade" e o que, a partir dela, pode ser dito sobre essa "exterioridade". E será pela observação das relações entre o corpo e a realidade 
psíquica que Bergson se desviará da profundidade própria à consciência para relacioná-la com o seu entorno.

Nesse processo, no entanto, Bergson encontrará como visão a ser superada, toda uma corrente de estudiosos dessas relações psico-fisiológicas que fundamentam suas investigações em pressupostos kantianos, assumindo o caráter inatingível da coisa em si e restringindo sua ciência a descrições fenomênicas, ou àquilo que se apresenta à consciência devidamente deformado ou informado pela sensação e pelo entendimento. No entanto, essa inacessibilidade da coisa em si, preconizada pelo kantismo, nos remete à nossa circunscrição ao interior da nossa consciência inaugurada pelo cartesianismo. Será, portanto, em última instância, a reprodução da exterioridade na interioridade da consciência que se mostrará a Bergson insustentável no decorrer de sua análise da relação entre essa consciência e o mundo exterior.

Até agora, com efeito, Bergson, apesar de suas considerações sobre o intelecto, não havia rompido com essa concepção da reprodução de uma exterioridade na interioridade da consciência. Parece-nos, com efeito, que, apenas ao analisar os mecanismos mesmos em que essa relação é descrita pela ciência de sua época que as incoerências em que elas estão assentadas se tornarão evidentes, o que levará Bergson para mais um grau de ruptura com o pensamento que o antecede.

E, parece-nos, portanto, que é para Matéria e Memória que devemos nos voltar se quisermos analisar tais relações, uma vez que ali é o lugar onde podemos, pela análise da percepção, (considerada até então como sensações representativas), ou seja, pela instância, por excelência, da relação entre o espírito e a matéria, acompanhar a construção de uma hipótese explicativa dessa relação, na qual a inteligência será considerada como uma ferramenta de ação; o que levará à crítica ao intelectualismo - e ao idealismo e realismo 
dele decorrentes —, e à delimitação dos campos de atuação do intelecto e da intuição, com a conseqüente afirmação da realidade da matéria e do espírito e a reiteração do método da precisão.

Com efeito, ao analisar o pensamento de sua época sobre as relações entre o corpo e o espírito, marcado, em suas várias vertentes, pela hipótese do paralelismo psicofisiológico, Bergson encontra contradições entre as teorias científicas nascentes, que progrediam na localização, no cérebro, da fonte de determinadas atividades psíquicas (entre as experiências mais bem sucedidas se destacavam as do Dr. Broca, que o levaram a circunscrever uma determinada circunvolução frontal do lóbulo esquerdo do cérebro como o centro da fala) e as teses metafísicas relativas à natureza da matéria a elas subjacentes — as concepções realista e idealista da matéria, uma considerando a matéria como coisa a outra como representação. Isso porque tais explicações das atividades psíquicas a partir de alterações sofridas pelo cérebro não conseguiriam se manter, do início ao fim, no registro de uma ou de outra tese metafísica, sendo levadas inadvertidamente do idealismo ao realismo, na tentativa de sustentar seu ponto de vista, para caírem, enfim, na contradição maior de não poder sustentá-lo por fundamentá-lo em dois pressupostos auto-excludentes, o que afirma que a matéria é uma coisa e o que afirma que a matéria é representação. No entanto, para além dessa inadequação entre as "descobertas" da ciência e as explicações metafísicas por estas assumidas, Bergson observa a insustentabilidade das próprias teses metafísicas em questão, insustentabilidade que residiria na posição intelectualista assumida por ambas, posição intelectualista que, nesse novo campo de investigação, aprofunda as conseqüências da transposição indevida, detectada no Ensaio, de mecanismos inerentes à prática para a especulação. 
Portanto, para além de suas diferenças, tanto o idealista quanto o realista partilhariam do ponto de vista intelectualista segundo o qual nossas percepções sensíveis, assim como os demais estados da consciência, são representações mentais, ou seja, que a percepção dos objetos exteriores (realista) ou que reputamos como exteriores (idealistas) ocorre na mente e não nas coisas. Nesse sentido, o realismo e o idealismo difeririam apenas porque o realismo postula a existência de um mundo exterior que causa essas representações, enquanto o idealismo se abstém de sustentar tal hipótese. Nesse sentido, ainda, é a própria postura intelectualista que se apresenta incongruente com as explicações dadas para a percepção sensível que surgem como um seu desenvolvimento natural; explicações já pressupostas em Descartes, sugeridas por Locke e encampadas pela psicofísica do século XIX .

Assim, para além da transposição indevida, detectada no Ensaio, dos mecanismos do entendimento, próprios à ação, para o domínio da especulação, a preeminência do entendimento, ao chegar ao auge na filosofia cartesiana, faz com que, a partir de então, ele se torne a essência da consciência que, por sua vez, se tornará a instância de reapresentação do mundo.

“as imagens de mundo"

Retomemos aqui aquilo que Heidegger pontuou sobre essa originalidade da modernidade, inaugurada por Descartes, em a "Época das "imagens de mundo"”, 17 a partir de suas considerações sobre a noção de sujeito e de representação, de subjetivo e objetivo então forjadas.

\footnotetext{
${ }^{17}$ Heidegger, M. "L'époque des 'conceptions du monde"”. In: Chemins qui ne ménent nulle part, Gallimard, Paris, 1990 .
} 
Com efeito, observa Heidegger, se Descartes faz recair sobre o homem, ou sobre o “eu”, a acepção de subjectum, não é porque ele tenha negado que este é a tradução do termo

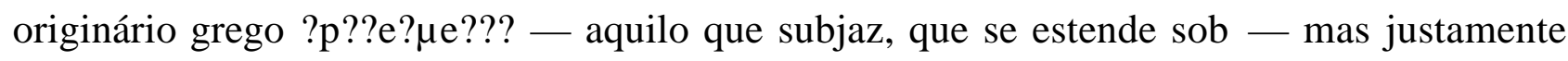
porque ele fez do "eu" esse fundamento por excelência, pelo qual tudo o que existe ou, como quer Heidegger, todo ente, ganha sua determinação e sua certeza. Mas então, é a uma nova concepção daquilo que existe que devemos, em primeira instância, nos remeter, para compreender uma nova relação estabelecida na modernidade entre a subjetividade e a objetividade.

Para Heidegger, a peculiaridade da noção daquilo que existe configurada por Descartes, em sua distinção em relação àquela presente tanto na antiguidade clássica, quanto na idade média, pode ser captada a partir da expressão "imagem de mundo". Isso porque a própria possibilidade de conceber uma imagem daquilo que existe, em sua totalidade, seria a característica fundadora da modernidade cartesiana. Mas de que modo especificamente o conceito de imagem determinaria a concepção daquilo que existe? Se levarmos em conta, como faz Heidegger, que o termo "imagem" (Bild) aponta tanto para as noções de reprodução, cópia, decalque, impressão de algo, quanto para o fato de se "estar a par de algo", podemos entender "imagem de mundo" como a possibilidade de colocar a totalidade daquilo que existe diante de uma existência especial, e fixá-lo nessa colocação (copiá-lo) para saber de que se trata (para ficar a par de). "Imagem" ("Bild") aponta ainda para um definir-se em relação a algo enquanto sistema — o que implica uma unidade interior ao representado enquanto tal —, e a um orientar-se sobre a coisa visada: "lá onde o mundo se torna imagem concebida (Bild), a totalidade do ente é compreendida e fixada como aquilo sobre o que o homem pode se orientar". Sendo assim, a própria aplicabilidade do termo "imagem" ao conjunto daquilo que existe determina o que é essencial a isso que existe, ou 
seja, o fato de que dele se possa fazer uma imagem, i.e., que aquilo que existe está dado naquilo que se fixa diante de uma atividade perscrutadora com vistas à ação, "o ser do ente é a partir de então procurado e encontrado no ser representado do ente".

Para melhor delinear essa concepção de mundo da modernidade, vale a pena, ainda, nos lembrarmos de como Heidegger enfatiza que ela não seria possível, por um lado, no pensamento medieval, uma vez que "para a Idade Média, ao contrário, o ente é o ens creatum, o que é criado pelo Criador, Deus pessoal agindo como causa suprema. Estar inserido na existência significa, então, pertencer a um grau determinado na ordem do criado e corresponder, enquanto assim causado, à causa criadora (analogia entis). Nesse sentido, a existência não poderia residir naquilo que, trazido diante do homem na qualidade de objeto, seria determinado e fixado em seu domínio de atribuição e disponibilidade, tornando-se ente apenas dessa maneira".

Por outro lado, como tal concepção de mundo também não caberia na antiguidade, uma vez que, a partir tanto de Parmênides quanto de Heráclito, "o ente é a expansão daquilo que se abre, daquilo que, em sua presença, chega ao homem como ao que é presente, quer dizer, como àquele que se abre à presença de presentes deixando compreendê-la, compreendendo, assim, a si mesmo". Mesmo a sofística, observa Heidegger, "só é possível sobre o fundo da sofia, quer dizer, da aceitação grega do ser como presença e da verdade como abertura irrestrita, que se mantém como uma determinação essencial do ser; por isso mesmo, a razão pela qual o presente se determina a partir da abertura irrestrita e a presença a partir da incondicionalidade como tal."

Se, então, é característica do pensamento moderno tornar o mundo imagem concebida, representação, é justamente porque o homem se atribui o conceito de subjectum proveniente da antiguidade clássica. Mas se, lá, subjcetum significava o substrato de 
qualidades e modos que nele se assentavam, portanto, aquilo que fundamenta indefinidamente o que existe, a modernidade, ao identificar o eu pensante a este subjectum, por meio da certeza de essência e de existência proveniente do cogito, vai fazer desse eu pensante o fundamento de tudo o que existe, na medida em que estes possam compartilhar dessa certeza própria a ele e dele proveniente. Assim, só existe aquilo que recebe a certeza de sua essência da atividade do subjectum/sujeito moderno. No entanto, a certeza que emana do cogito é a certeza da clareza e da distinção na qual ele mesmo se afirma e, nesse sentido, o existente não pode estar naquilo que percebemos pela sensibilidade (idéias sensíveis), por si mesmo confuso e indistinto, mas nas idéias (idéias intelectuais). É nesse sentido que todo o mundo sensível se transforma em sinais do mundo exterior que é conhecido pelas imagens/idéias que deles fazemos por meio da atividade pura do pensamento. Assim, o sensível é totalmente desqualificado enquanto o estabelecimento daquilo que existe depende, agora, da atividade cogitativa do sujeito.

Aonde chegamos? De uma crítica à transposição indevida de método, à crítica à própria concepção daquilo que existe. Mas, antes, à crítica da relação entre o eu e o mundo. Para Bergson, com efeito, aqueles instrumentos com os quais o eu age sobre o mundo não podem ser medida da realidade do mundo. Mas, mais do que isso, a totalidade do mundo não pode ser reproduzida em sua integralidade em uma consciência. Para ele é bastante claro que a consciência está no mundo, e não o mundo na consciência. E acreditamos que essa clareza tenha advindo, em boa parte, da observação das relações entre a atuação do cérebro e a constituição da consciência. Pois, é fato que, se Descartes admite a possibilidade, que ele deve trabalhar para refutar, da inexistência do mundo exterior à consciência, ao afirmar tal mundo, é necessário assumir que a relação direta entre o mundo e a consciência deve passar pela materialidade do corpo. Relação que, de resto, Descartes 
afirma na Sexta Meditação, ainda que se abstenha de tentar explicá-la, mesmo porque, segundo ele, tal relação, naturalmente confusa, seria compreensível pelo senso comum e não por meio das idéias claras e distintas do intelecto. Se, para Descartes, a falta de tal explicação não redunda em grandes problemas para o conhecimento, uma vez que este se assenta em idéias inatas e na racionalidade inerente ao intelecto e ao mundo, tal explicação será o mote mesmo do conhecimento fundado na experiência do século XIX e XX, especificamente da psicofísica, que, no entanto, reproduzirá a relação assumida por Descartes entre o mundo exterior e consciência por meio da intermediação do cérebro.

No entanto, a própria crítica sobre o papel do corpo na relação entre a consciência e a matéria se constitui como o primeiro estágio de aplicação do método intuitivo, anteriormente aplicado à essência dessa consciência, agora à essência dessa relação. Uma vez que, afastada a possibilidade de o corpo ser produtor de representação, seu papel na constituição dessa representação pode ser dimensionado em termos reais, a saber, como o de vetor da ação do espírito na matéria da qual ele faz parte e, nesse sentido, da constituição da consciência co-extensiva à essa relação

Acreditamos, portanto, que é justamente nessa volta à observação da experiência da percepção, descrita em Matéria e Memória, quando então Bergson critica o papel do corpo e, nesse sentido, a hipótese segundo a qual tal percepção se dá como representação de uma realidade no interior de uma consciência, que ele também é levado, por outro lado, a sustentar a hipótese de que a percepção aponta, ao contrário, para a constituição dessa consciência no interior dessa realidade. Desse modo, tanto ele reintroduz a percepção no percebido, quanto se remete a um horizonte de indistinção entre percebido e percepção. Portanto, é pela aplicação do método intuitivo ao fenômeno da percepção, que Bergson teria sido levado a criticar seu caráter simples, donde a impossibilidade de, por ela, compreender 
a duplicidade da realidade que, nela se relacionariam, e afirmar seu caráter misto, no qual, justamente, apreenderíamos, "ao mesmo tempo, um estado de nossa consciência e uma realidade independente de nós".

Para ele, com efeito, por tal hipótese seria possível evitar as contradições nas quais o dualismo clássico se enreda, sem ter de abdicar a ele, mantendo, assim, a crença do senso comum, da qual ele parte no início de sua investigação, segundo a qual percebemos a realidade ainda que tal realidade seja independente de nossa percepção (e, ainda, de quebra, conferir realidade, por um lado à ciência, como conhecimento que toca o absoluto ao se fundar efetivamente na matéria, e, por outro, à metafísica, como conhecimento que toca o fundo absoluto do espírito).

Se nem todas as conseqüências de tal hipótese explicativa foram amplamente desenvolvidas em Matéria e Memória, elas, no entanto, estão ali em germe. Uma vez que a crítica ao intelectualismo ali desenvolvida, que explicita a função prática e não especulativa do entendimento, pode ser considerada como o passo anterior e necessário ao aprofundamento dessa crítica realizada em Evolução Criadora - obra na qual qualquer pretensão ao conhecimento da totalidade do que existe será mais uma vez negado ao entendimento, uma vez que, situado em uma das etapas do desenvolvimento da vida, este não poderia nos dar a compreensão da vida como um todo. Com efeito, Matéria e Memória mostra-se um ponto privilegiando de onde observar o pensamento de Bergson, uma vez que, estando a meio caminho de seu pleno desenvolvimento, tem como pressuposto o método pelo qual esse pensamento se guia, bem como sua primeira descoberta - a realidade da duração na consciência - e preconiza a extrapolação dessa duração para o conjunto da realidade bem como apresenta um exemplo particular da ampliação da crítica de Bergson iniciada com a anterior proposição de seu método. 
Quanto a estes dois últimos pontos algumas palavras finais.

Em primeiro lugar, podemos antever, na representação cartesiana criticada em Matéria e Memória, uma modalidade daquela tendência do pensamento filosófico, identificada e criticada nos textos posteriores de Bergson, a postular a precedência do Nada e do Caos sobre o Ser e a Ordem. Precedência que, segundo Bergson, se expressa em questões, consideradas "filosóficas” por excelência, do tipo: “Como é possível que qualquer coisa exista - matéria, espírito, ou Deus?"; "Por que uma realidade ordenada, em que nosso pensamento se encontra como num espelho? Por que o mundo não é incoerente?". ${ }^{18}$ Tais questões, com efeito, só seriam colocadas porque se admite que há uma precedência ontológica do nada ou do caos em relação ao ser e à ordem; e que, portanto, o ser e a ordenação pela qual ele é, viriam preencher um vazio e uma falta. No entanto, é o próprio vazio e a falta total de qualquer ordem que são incompreensíveis. E, paradoxalmente, nos manteremos diante dessa incompreensão se nos mantivermos no registro do intelecto que visa, justamente, compreender a totalidade da realidade com a sua lógica. Seria, portanto, por um dilatamento de nossa vontade que, ao nos recolocar no movimento de engendramento da realidade, nos fizesse redimensionar a atuação do intelecto e perceber o caráter descabido de tais questões. Se não o fazemos, e continuamos a nos questionar sobre o porquê do ser ou, por que não o nada, deve-se ao fato de nos encontrarmos com o mesmo déficit de vontade daquele homem que volta inúmeras vezes para verificar uma fechadura, sem nunca alcançar a certeza de tê-la efetivamente trancado, afinal, "como estar certo, definitivamente certo, de que fizemos o que queríamos fazer?" Um homem, que assim se questionasse, não estaria, segundo a perspectiva de Bergson, vendo algo que outros não viram, levantando uma questão positiva sobre determinado fato, mas, apenas, expressando sua capacidade de agir "lesada", sua "meia-vontade", que só poderia lhe dar uma "meia

\footnotetext{
${ }^{18}$ Bergson, H. 1950, p. 65.
} 
certeza”. No entanto, ao tomar consciência dessa ilusão, o entendimento se corrige e percebe que "não pode suprimir um arranjo sem que outro o substitua, fazer desaparecer a matéria sem que uma outra a substitua" ${ }^{19}$ e que foi por não encontrar o ser ou a ordem que melhor lhe conviesse, que transportou essa decepção para o campo da especulação e teorizou sobre o nada e sobre o caos. “'Desordem' e 'nada' designam, pois, realmente, uma presença - a presença de uma ordem ou de uma coisa que não nos interessa, que decepciona nosso esforço ou nossa atenção; é nossa decepção que exprimimos quando chamamos a esta presença de ausência. (...) Quando o filósofo fala de caos e de nada, ele só faz transportar para a ordem da especulação - elevadas ao absoluto e esvaziadas por isso de todo sentido, de todo conteúdo efetivo — duas idéias feitas para a prática e que se referiam então a uma espécie determinada de matéria ou de ordem, mas não a toda ordem, não a toda matéria.",20

Como então essa crítica bergsoniana à precedência do nada e do caos pode ser aplicada a Descartes e, por extensão, ao intelectualismo moderno? Ora, mas o enclausuramento do sujeito no universo representativo não significaria a possibilidade mesma de não existência do mundo para além dessa representação? Não seria uma "fraqueza da vontade" a responsável por não assumir que estamos imersos no mundo, ou que somos presença em um campo transcendental de presenças, ${ }^{21}$ e que a realidade do mundo está dada desde sempre, e não precisa ser provada ao final de um périplo em que sua realidade tenha sido medida por critérios buscados fora dela e que se aplicam apenas à sua re-apresentação? Tal crítica podemos encontrar ali, em Matéria e Memória, quando Bergson assume como dado o universo das imagens, quando nega a necessidade de explicar o surgimento do mundo enquanto imagem no interior de uma consciência. Quando explica as

\footnotetext{
${ }^{19}$ Bergson, H. 1950, p. 67.

${ }^{20}$ Bergson, H. 1950, p. 67-68.

${ }^{21}$ Cf Prado Jr., B. Presença e Campo Transcendental, São Paulo, Edusp, 1989.
} 
percepções sensíveis, não como estados da mente, mas como o resultado da ação de uma consciência na coisa de que se toma consciência. Quando rompe com a remissão indefinida à causa da causa e assume $o$ mundo como dado, não dado no interior de uma consciência, mas dado em si mesmo, no mundo. Nesse novo contexto, portanto, não é mais a reapresentação do dado no interior das consciências que se tem de explicar, mas como consciência e dado se distinguem no interior da presença.

A hipótese da percepção, então apresentada em Matéria e Memória, avança ainda, em suas consequiências metafísicas, para a extrapolação da duração para além da própria consciência - tema retomado em Evolução Criadora - fazendo dessa percepção o resultado da atuação de uma duração sobre outra.

Levando em conta, portanto, as possibilidades de abordagem do pensamento de Bergson a partir de Matéria e Memória, nos propomos, ao percorrer a análise da percepção e suas conseqüências metafísicas desenvolvidas no primeiro e quarto capítulos desse livro, tratar de pontos que consideramos essenciais à sua doutrina, ou seja, a relação entre o método por ele proposto e a sustentabilidade do novo dualismo dele resultante, o que implica uma crítica aos pressupostos do intelectualismo e, nesse sentido, uma nova concepção de Ser e de conhecimento.

Não poderíamos deixar de mencionar ainda que o pensamento moderno criticado por Bergson já teria uma voz destoante na figura da filosofia de Berkeley, cujo pensamento em alguma medida já preconizaria uma crítica à teoria da representação. Isso porque parece-nos que a essência do imaterialismo de Berkeley reside exatamente no fato de este negar a duplicidade do mundo real no interior de uma consciência. Com efeito, para Berkeley, a consciência, ou o ser que percebe, tem acesso direto ao mundo que é criação contínua de Deus para ele. Acesso direto que, no caso de Bergson, é garantido pela presença do espírito 
em um campo transcendental ${ }^{22}$ de imagens. Nesse sentido, ainda, Berkeley e Bergson concordariam no fato de ambos considerarem que a experiência vivida pela consciência não se restringe àquilo que lhe é dado imediatamente, mas a uma ação que perpassa essa doação, tanto ao corpóreo, percipe, quanto ao espiritual, percipere. Nesse sentido ainda, e segundo as distinções efetuadas por Heidegger apresentadas acima, Berkeley estaria muito mais afeito ao pensamento medieval e Bergson à antiguidade clássica, pois, ambos, de qualquer forma, não se encaixariam nos moldes de um pensamento que colocasse o sujeito como sustentáculo do mundo, ainda que acreditassem alcançar o mundo a partir da experiência do sujeito.

${ }^{22}$ Cf. Prado Jr., 1989. 


\section{PERCEPÇÃO E REPRESENTAÇÃO}

Ao iniciar o capítulo no qual irá desenvolver sua teoria da percepção, Bergson nos convida a não tomarmos nenhum posicionamento diante das diferentes afirmações da filosofia sobre a natureza da matéria ou do espírito. E, especificamente, ao procurarmos construir uma hipótese explicativa daquilo que ocorre quando afirmamos perceber o mundo que nos cerca, Bergson propõe que não sejamos de antemão nem realistas nem idealistas ${ }^{1}$, mas que, diante do mundo, evitemos, por um lado, pressupor a existência de coisas subjacentes e, por outro, reduzi-lo a representações interiores a uma consciência, e que sigamos descrevendo aquilo que nos aparece sem, portanto, supor que aquilo que nos

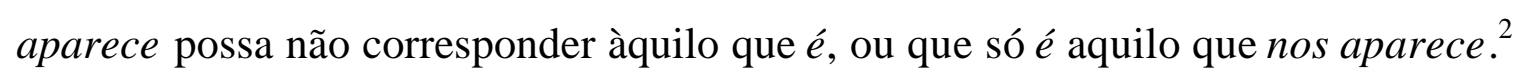

Sendo assim, ao olharmos para o mundo, ou, como quer Bergson, ao abrirmos nossos sentidos, o que ocorre? "Eis-me, então, diante de image ns, no sentido mais vago pelo qual possamos tomar essa palavra."

Ao observar, a partir daí, o comportamento dessas "imagens" — "nem coisas, nem representações" - constataríamos também que elas atuam umas sobre as outras, ou seja, modificam-se e, mais, modificam-se a partir de uma relação estabelecida de forma constante. E, de tal modo, que essas constâncias poderiam ser enunciadas sob a forma de leis, pelas quais todas as modificações futuras seriam passíveis de previsão. Previsibilidade potencialmente absoluta que leva Bergson a afirmar que todas as relações futuras passíveis de serem estabelecidas entre essas imagens estariam contidas em seu

\footnotetext{
${ }^{1}$ Bergson, H. 1999, p. 12: "Nous allons feindre pour un instant que nous ne connaissions rien des théories de la matière et des théories de l'esprit, rien des discussions sur la réalité ou l'idéalité du monde extérieur."

${ }^{2}$ Como Bergson já havia adiantado na Introdução à Matéria e Memória, (Bergson, H. 1999, p. 2): "Em uma palavra, consideramos a matéria antes de qualquer dissociação que o realismo e o idealismo tenham operado entre sua existência e sua aparência".

${ }^{3}$ Bergson, H. 1999, p.11.
} 
presente, e que a essas imagens nada se lhes "pode acrescentar de novo" ${ }^{4}$. Entre essas imagens, no entanto, existem algumas que se destacam. E se destacam por manter, além daquela relação de exterioridade até então detectada, também uma relação de interioridade com o observador: "No entanto, há uma que se destaca de todas as outras, na medida em que não a conheço somente por fora, pelas percepções, mas também por dentro, pelas afecções: meu corpo". 5

Sendo assim, me parece, quando em presença dessas imagens, que tenho acesso à maioria delas de um ponto de vista exterior, quando eu me abro para elas - o que denota uma existência independente da minha - mas que algumas dentre elas me aparecem também a partir de um segundo ponto de vista, este, interior - o que denota uma existência intimamente ligada à minha, que de fato desapareceria se eu não existisse. E isso é tudo o que podemos afirmar sobre essa relação até o momento de nossa observação. Poderíamos ir mais longe talvez apenas na constatação de que esse corpo, que reputo como meu, e ao qual chego pela distinção de um grupo de imagens que conheço sob dois pontos de vista, tem a peculiaridade de, além de se dar a si mesmo como espetáculo, dar também outras imagens nesse mesmo movimento. ${ }^{6}$

É de se notar, no entanto, que, apesar de ter nomeado nosso acesso a essa imagem que se destaca das demais com o termo afecção, Bergson evita definir tal afecção nesse momento, não chega nem mesmo a nos esclarecer se tais afecções seriam apenas as sensações de dor e prazer ou também as demais sensações que podem ser experimentadas pelo meu corpo, sem entrar em detalhes que o comprometessem com distinções filosóficas que ele se vê interditado de fazer, ao menos até aqui. Assim, logo após ter

\footnotetext{
${ }^{4}$ Idem, ibidem.

${ }^{5}$ Idem, ibidem.

${ }^{6}$ Cf. Prado Jr., B. 1989, p. 143.
} 
enunciado as afecções ele passa a determinar as condições em que elas se dão. Condições que vão englobar tanto a experiência empírica da qual partimos, quanto nossos conhecimentos científicos e a consciência que temos dessas afecções.

Em que condições, portanto, constato a presença dessas afecções? Constato que as afecções, que são signo do meu corpo, se interpõem entre os estímulos que atingem esse corpo e os movimentos por ele executados; movimentos que, no entanto, não se seguem necessariamente aos estímulos recebidos, mas que podem se fazer esperar e, mesmo, não ocorrer. Constato também que esse tipo de sensação particular não me parece ser peculiaridade minha, mas peculiaridade de todo organismo vivo que, por ser capaz de se mover no espaço, se vê exposto a perigos dos quais é advertido justamente por essas sensações, sensações que então dirigirão sua ação. E constato, ainda, interrogando minha consciência, que esta se faz presente naquelas afecções das quais se seguem ações que envolvem alguma iniciativa e que se opõem àquelas que se seguem automaticamente das afecções.

Temos então dadas as condições em que percebemos surgirem as afecções e que justamente demarcam um campo de relações que se destaca no universo das demais imagens, ou seja, por oposição ao universo da necessidade, então imperante, vemos destacar-se o universo da possibilidade. No lugar daquelas ações que se seguem previsivelmente umas das outras, destaca-se o convite à ação, ou mesmo uma autorização para esperar ou nada fazer; no lugar da ação cega, a escolha e a decisão; no lugar do automatismo, a iniciativa. ${ }^{7}$ No entanto, o que interessa a Bergson aqui não é tanto aquilo que, nessas condições, diz respeito a uma subjetividade, ou, poderíamos mesmo dizer, a uma vontade — o fato de essas afecções envolverem um convite, uma

\footnotetext{
${ }^{7}$ Idem, p. 12.
} 
escolha e uma decisão —, mas aquilo que diz respeito às ações que se efetuam entre as imagens das quais se partiu, nesse caso, sua indeterminação. Indeterminação que aparece então como a marca característica daquilo que introduz o novo que até então não aparecia no sistema. O que leva Bergson a afirmar: "Ou bem todas as aparências são enganosas, ou o ato no qual o estado afetivo resulta não é do tipo dos que podem ser rigorosamente deduzidos dos fenômenos anteriores como um movimento de um movimento, de tal forma que introduz algo de novo ao universo e à sua história". ${ }^{8}$ Assim, partindo daquilo que aparece a um observador, sem levar em conta qualquer conhecimento estabelecido sobre a natureza disso que aparece, é possível enunciar o seguinte princípio: 'Tudo se passa como se, no conjunto de imagens que chamo de universo, só poderá ser produzido algo de realmente novo por intermédio de certas imagens particulares, cujo tipo me é dado por meu corpo". 9

E, desde então, tudo está dito, como notou Worms ao nos chamar a atenção para o caráter exaustivo desse primeiro parágrafo de Matéria e Memória: “Tudo está dado e nada mais poderá ser acrescentado: a seqüência do capítulo deverá “compor” esses dois termos fundamentais, as imagens em seu conjunto, e meu corpo, generalizando, apenas, por analogia, o 'tipo' deste último". 10

Talvez possamos ir além e afirmar que o conteúdo essencial do livro está aqui implicado, uma vez que é por assumir um campo de imagens como ponto de partida, que se dará, ao mesmo tempo, tanto a matéria quanto a consciência da matéria; e pela circunscrição à interioridade desse campo, caracterizado por relações passíveis de serem apreendidas na forma da necessidade e por aquelas que se furtam a tanto, pela introdução, portanto, de um

\footnotetext{
${ }^{8}$ Idem, ibidem.

${ }^{9}$ Idem, ibidem.

${ }^{10}$ Worms, F. 1997, p. 24.
} 
princípio organizador, se aponta para a possibilidade de apreensão da natureza íntima dessa matéria e de algo que não se reduz a ela, que aponta, enfim, para o espírito.

Iniciemos, então, examinando o significado dessas "imagens", das quais tudo principia.

imagens

E iniciemos pela questão de se a suposta neutralidade em relação às teses metafísicas e epistemológicas do realismo e do idealismo, propostas no primeiro parágrafo, não se veria, desde então, comprometida com a proposição do termo "imagem”, uma vez que o termo “imagem”, segundo sua “acepção mais vaga possível” já implicaria um posicionamento claro em relação às questões filosóficas às quais se deveria abstrair. E isto porque, mesmo tomado o termo "imagem" nessa acepção vaga, este já determina ao menos duas coisas: algo passível de ser apreendido por um espectador e, consequentemente, algo que aparece a esse observador como distinto dele. Além dessas duas determinações positivas podemos acrescentar uma terceira negativa, a saber, a imagem, que aparece como algo exterior àquele que a percebe, não contém em si qualquer marca de algo além dela e à qual ela se remeteria.

Desde sempre, portanto, ao se referir àquilo que percebemos pelos sentidos por meio do termo "imagem", explicita-se a indicação de uma presença diante da qual nos postamos e, nesse sentido, de uma realidade de algum modo independente e distinta acessada nessa percepção: "Eis-me diante de imagens, no sentido mais vago em que possa tomar esse 
termo, imagens percebidas quando abro meus sentidos, não percebidas quando os fecho."11

A forma mesma dessa independência, distinção e acesso que relacionaria o campo de imagens, a percepção e o percebido, é o que Bergson procurará delimitar em todo esse primeiro capítulo; a partir do que a hipótese da percepção por ele defendida se distinguirá daquelas propostas pelo idealismo e realismo. Assim, o termo "imagem" apresenta-se tanto como o ponto de partida para a explicitação da hipótese de Bergson, quanto para a crítica na qual essa explicitação se apóia.

Com efeito, para tomarmos o termo "imagem" como um marco zero, a faxina a qual devemos submetê-lo não deverá ser pequena, pois os sentidos por ele acumulados no decorrer da história da filosofia e, mais especificamente, sua acepção no contexto das teorias da representação, a partir de Descartes, e na psicofisiologia do século XIX que, em certa medida, pode ser considerada como um eco do representacionismo clássico, não são pouca coisa. Tomemos aqui apenas aquelas acepções que dizem respeito à teoria do conhecimento, nosso objeto de análise no momento, deixando para adiante a retomada de suas acepções metafísicas, segundo a qual, como propôs Heidegger, o termo não apenas expressaria uma determinada maneira de conhecer o mundo, mas também de concederlhe realidade. ${ }^{12}$

Então, vejamos.

Como sabemos, Descartes, no seu esforço em cunhar um novo sentido ao termo "idéia", relaciona-o várias vezes ao termo "imagem". No contexto da filosofia cartesiana, portanto, imagem caracterizará, antes de mais nada, "maneiras ou formas de pensar do

\footnotetext{
${ }_{11}^{11}$ Bergson, H. 1999, p. 11.

${ }^{12}$ Assim como foram propostas por Heidegger, em seu L'Époque des images du monde, comentado na Introdução a este texto.
} 
espírito"13. Nas Meditações, como correlato das idéias intelectuais das coisas, o termo imagem é usado estritamente por sua referência à função representativa; idéia, nesse sentido, é toda representação, em uma mente, que corresponde a um original fora dela. ${ }^{14}$ Assim, Descartes afirma: "Entre os meus pensamentos, alguns são como as imagens das coisas, e só àqueles convêm propriamente o nome de idéias: como no momento em que eu represento um homem ou uma quimera, ou o céu, ou um ano, ou mesmo Deus". ${ }^{15}$ Podemos dizer ainda que tais idéias-imagens distinguem-se daqueles outros modos do espírito, denominados vontades, afecções e juízos, justamente por referirem-se mais às coisas representadas - como uma sua imagem — do que ao sujeito da representação — suporte dessa imagem —, uma vez que a essas idéias-imagens nenhuma ação deste sujeito teria sido acrescentada como conteúdo. ${ }^{16}$

Mas o termo imagem também é utilizado por ressaltar o caráter pictórico das idéias ditas sensíveis, caráter que encarnaria a distinção mesma entre as imagens-representações claras e distintas concebidas pelo intelecto e estas imagens-representações consideradas obscuras e confusas por Descartes, e que seriam impressas, a partir dos sentidos, na imaginação, ou mesmo concebidas pela imaginação a partir da combinação de outras imagens nela impressas anteriormente. Assim, tomando como parâmetro as idéias que tenho dos corpos, ao lado daquelas que concebo "clara e distintamente: a saber, a grandeza ou a extensão em longura, largura e profundidade; a figura que é formada pelos

\footnotetext{
${ }^{13}$ Descartes, R. Méditations métaphysiques, $3^{\mathrm{e}}$ ed., Paris, Quadrige / Puf, Paris, 1992, "Meditação Terceira”, § 17.

${ }^{14}$ No contexto da prova da existência de Deus: "E ainda que possa ocorrer que uma idéia dê origem a uma outra idéia, isso todavia não pode estender-se ao infinito, mas é preciso chegar ao fim a uma primeira idéia, cuja causa seja um como padrão ou original, na qual toda realidade ou perfeição esteja contida formalmente e em efeito, a qual só se encontra objetivamente ou por representação nessas idéias. De sorte que a luz natural me faz conhecer evidentemente que as idéias são em mim como quadros, ou imagens, que podem na verdade facilmente não conservar a perfeição das coisas de onde foram tiradas, mas que jamais podem conter algo de maior ou mais perfeito". Descartes, R., 1992, "Meditação Terceira", § 17.

${ }^{15}$ Descartes, R. 1992, "Meditação Terceira”, § 6.

${ }^{16}$ Idem, ibidem: "Outros, além disso, têm algumas outras formas: como, no momento em que eu quero, que eu temo, que eu afirmo ou que eu nego, então concebo efetivamente uma coisa como o sujeito da ação de meu espírito, mas acrescento também alguma outra coisa por esta ação à idéia que tenho daquela coisa; e deste gênero de pensamentos, uns são chamados vontades ou afecções, e outros juízos."
} 
termos e pelos limites dessa extensão; a situação que os corpos diferentemente figurados guardam entre si; e o movimento ou a modificação dessa situação; aos quais podemos acrescentar a substância, a duração e o número"; encontram-se em meu pensamento aquelas obscuras e confusas como "a luz, as cores, os sons, os odores, os sabores, o calor, o frio e as outras qualidades que caem sob o tato". ${ }^{17}$

Fiquemos, pois, com os dois sentidos de "imagem" que gravitam em torno da caracterização da idéia cartesiana: aquele que se refere à função de representante, na mente, de originais que estariam fora dela, e que envolve um trabalho do intelecto; e aquele que se refere a essa mesma função representativa que se efetuaria, no entanto, no nível da imaginação e, portanto, que se refere especificamente ao conteúdo pictórico de algumas dessas idéias que têm como fonte os órgãos dos sentidos. Vale lembrar, ainda, que tais conteúdos aportados pelos sentidos à faculdade da imaginação e que, segundo a classificação de Descartes, "vêm de fora", nem por isso podem ser considerados "semelhanças, impressas em mim, por essas coisas que existem fora de mim". ${ }^{18}$ Ao contrário, as idéias-imagens forjadas pelo intelecto, justamente por serem claras e distintas — pelo que se distinguiriam destas obscuras e confusas dos sentidos - seriam, por isso mesmo, muito mais fidedignas, marca mesma da distinção existente, para Descartes, entre a percepção e a realidade percebida.

Temos, então, que as imagens são idéias, ou modos assumidos pela mente, que representam, de forma pictórica ou não, com maior ou menor fidedignidade, objetos exteriores. Temos, portanto, a interioridade de um indivíduo como substrato da reapresentação de uma realidade exterior a ele, um sujeito que se opõe a um objeto e que, no entanto, possui, inscrito em si e, portanto, de forma indireta, um acesso a esse objeto.

\footnotetext{
${ }^{17}$ Descartes, R.1992, "Meditação terceira”, § 19.

${ }^{18}$ Cf. Descartes, R. "Meditação terceira", §§ 10 e 14.
} 
Temos, finalmente, com o termo imagem, a circunscrição exata de uma re-apresentação e, com ele, toda uma teoria epistemológica que sustenta um acesso intermediado, pela interioridade de um sujeito constituído, à exterioridade do mundo; intermediação implicada, por sua vez, na hipótese metafísica da distinção radical entre essas duas realidades justamente pela exterioridade de uma em relação à outra, ou, se quisermos, pela espacialidade. Sendo assim, no contexto do cartesianismo, (ou mesmo de um empirismo de tipo lockeano ou hobbesiano), o termo imagem, por um lado, caracteriza o modo assumido por uma realidade, a do pensamento que, por sua vez, é aquilo mesmo que caracteriza o espírito, ou o substrato desse pensamento; e, por outro lado, refere-se à realidade de algo que existe como exterior a esse sujeito e que lhe é inacessível diretamente: a matéria. É, de se notar, no entanto, que a própria caracterização do espírito a partir da esfera do sujeito que se mantém intacta após a metodológica suspensão de juízo em relação a tudo o que não é a consciência identitária desse mesmo sujeito, feita pelo realismo cartesiano, é o que separa esse sujeito e, por conseqüência, o espírito, de tudo o que não é ele próprio, ou seja, a matéria. E é essa abstração ou separação radical exigida pelo cogito entre essas "duas regiões de seres" que implica a necessidade de uma re-apresentação da matéria por uma "imagem", intelectual ou sensível, no âmbito da realidade do espírito. Nesse sentido se, formalmente, a "imagem" é eminentemente dependente do espírito, uma vez que é um modo da mente, objetivamente ela remete a uma realidade totalmente independente, a própria res extensa que, nesse sentido mesmo, não é em si qualificável sensivelmente (distinção cara ao cartesianismo, uma vez que a matéria é afirmada como uma realidade que não pode ser intuída diretamente pelo espírito). 
No entanto, a referência à concepção idealista da matéria, também presente no primeiro parágrafo de Matéria e Memória, e caracterizada no Prefácio como aquela posição que identificaria a matéria à representação e, portanto, que se oporia à identificação realista da matéria com a coisa exterior e causa dessas representações, nos permite circunscrever um outro uso do termo "imagem", restrito agora apenas a essas representações, que seriam então, necessariamente, representações sensíveis (uma vez que não haveria realidade oculta a ser alcançada pela representação do intelecto), sem qualquer referência a uma realidade exterior. Nesse registro idealista, portanto, o termo "imagem" só se remeteria àquilo que, na interioridade de um sujeito, se apresenta como qualidade sensível, mantendo-se a realidade da coisa exterior ao sujeito, hipoteticamente representada por essas qualidades, em eterna suspensão ou, mesmo, peremptoriamente negada. Podemos dizer que a primeira atitude seria característica daquele ceticismo no qual Descartes se coloca metodologicamente e acredita ter podido superar. A segunda é nominalmente identificada por Bergson ao idealismo de Berkeley. ${ }^{19}$ Certamente muito teríamos a discutir sobre a identificação do percipi de Berkeley à representação cartesiana, como pressupõe uma abordagem dessa filosofia como uma filosofia da representação. Voltaremos a essa questão quando analisarmos mais detidamente a crítica de Bergson a essas duas concepções da matéria representadas pelo idealismo e pelo realismo. Basta notarmos, por ora que, nesse sentido chamado de idealista por Bergson, não só o termo imagem, mas também o termo matéria seriam sinônimos de representação, uma vez que ao identificar a matéria às suas qualidades sensíveis ela se

\footnotetext{
${ }^{19}$ Bergson, H. 1999 , p. 2-3.
} 
restringiria, juntamente com essas qualidades, ao âmbito do sujeito, confundindo-se com ele. $^{20}$

Limitemo-nos, portanto, a observar como a utilização do termo "imagem”, pelo idealismo e pelo realismo, remete a todo aquele arcabouço teórico que Bergson está procurando evitar ao iniciar, de um ponto de vista que seria anterior ao de tais posicionamentos filosóficos, sua análise do fenômeno da percepção que resultará em um nova concepção da natureza tanto da matéria quanto do espírito. Concepção que justamente se oporá a distinção, promovida pelo realismo cartesiano entre uma res extensa e uma res cogitans, a qual implicou a necessidade dessa intermediação, a imagem-representação-sensível, entre uma e outra. Distinção, finalmente, encampada pelo idealismo - ao menos aquele descrito por Bergson - ainda que seja para posteriormente assumir apenas a res cogitans e seus modos.

Nesse sentido, a “imagem” da qual Bergson partirá para desenvolver sua análise, deve ser aquela realidade dada no ponto comum do qual também partiriam tanto idealistas quanto realistas, ou seja, as percepções sensíveis, sem, no entanto, a interpretação que a ela está aderida, ou seja, a interpretação de que essa percepção está inscrita, é parte do sujeito que percebe, podendo, então, apenas posteriormente, ser ou não referida a uma outra realidade fora deste sujeito e desta percepção. Bergson, propõe, portanto, que partamos do fenômeno da percepção como assentado na própria realidade, que, no entanto, extrapola essa mesma percepção, o que, afinal, é o conceito mesmo de mundo material do senso comum:

\footnotetext{
${ }^{20}$ Cf. Bergson, H. 1999, p. 2-3 :Um grande progresso foi realizado em filosofia no dia em que Berkeley estabeleceu, contra os "mechanical philosophers", que as qualidades secundárias da matéria tinham ao menos tanta realidade quanto as qualidades primárias. Seu erro foi acreditar que para isso seria necessário transportar a matéria para o interior do espírito e fazer dela pura idéia".
} 
O quanto não surpreenderíamos um homem pouco familiarizado com as especulações dos filósofos ao dizer-lhe que o objeto que ele tem diante de si, que ele vê e que ele toca só existe em seu espírito (...). Nosso interlocutor não deixaria de sustentar que o objeto existe independente da consciência que o percebe. Mas, por outro lado, também surpreenderíamos esse interlo cutor ao dizer-lhe que o objeto é totalmente diferente daquilo que percebemos nele, que ele não tem nem a cor que o olho lhe atribui, nem a resistência que a mão nele encontra." 21

Nesse sentido, a matéria de Bergson, identificada ao mundo material do leigo, é justamente o lugar daquelas qualidades sensíveis — imagens — que subsistem por si mesmas, ou seja, aquela "existência que é mais do que o idealista chama de representação, mas menos do que o realista chama de coisa, - uma existência situada a meio caminho entre a 'coisa' e a 'representação"'.22

Em que, especificamente, esta matéria-imagem equivaleria e em que ela excederia à representação, de um lado, e à coisa, de outro? Ora, a matéria, para Bergson, é aquilo mesmo que se coloca diante de nossos sentidos, que vemos e que tocamos, mas que não existe apenas para ou em nossos sentidos, como quereria o idealista, mas como coisa independente de nós. Por outro lado, se as coisas existem independentemente do fato de serem percebidas, elas não são de natureza diferente disso que é percebido, ou, como quereria o realista, causas dessas percepções. É nesse sentido, portanto, que, ao lado do senso-comum, Bergson chama nossa atenção para o contra-senso em afirmar que a cor, o tamanho, a textura não são qualidades percebidas nos objetos, mas estados da mente que os percebe, posição esta assumida tanto pelo realista quanto pelo idealista descritos por Bergson. Sendo assim, a matéria-imagem de Bergson equivale à 'representação' do idealista, porque possui todas as qualidades nela percebidas, e se distingue dessa mesma representação porque não existe como um estado de nosso espírito, portanto, como dependente dele. Em contrapartida, a matéria-imagem equivale à 'coisa' do realista, porque é independente de nosso espírito, e se distingue dela porque, mesmo independente, pode ser

\footnotetext{
${ }^{21}$ Bergson, H. 1999, p.2.

${ }^{22}$ Bergson, H. 1999, p.1.
} 
intuída por esse espírito, não sendo, portanto, de natureza diferente das representações que ele tem dela.

Em resumo, ao afirmar que o mundo material percebido ao abrirmos nossos sentidos se resume a imagens, Bergson propõe que esse mundo existe por si mesmo e que nós o percebemos, como cor, som, textura etc. nele mesmo, portanto, em sua própria realidade, sentido em que se dá a afirmação segundo a qual a matéria é "uma imagem, mas uma imagem que existe por si." 23

Será, assim, pela análise desse campo de imagens, que ele então encontrará todos os elementos necessários para, nele, distinguir a matéria, a consciência e a consciência da matéria.

É nesse sentido, também, que o termo ‘imagem', usado por Bergson para designar a matéria, justamente por remeter àquela concepção de matéria que ele deseja criticar, aquela que se fundamenta em uma distinção de natureza entre o que a matéria é e o que dela se dá na experiência, ou seja, a distinção clássica, feita pelas filosofias da representação, entre a realidade e a aparência/experiência da matéria, presta-se muito bem para afirmar sua própria concepção dessa distinção.

Pois se a matéria, como "imagem”, remete à sua acessibilidade por uma consciência, como 'Imagem que existe em si”, remete ao fato de que tal acessibilidade não implica a duplicação ou re-apresentação dessa realidade na interioridade dessa consciência. A matéria é imagem, portanto, uma realidade acessível a uma consciência, mas acessível nela mesma, e essa será a grande tese da teoria da percepção de Bergson. Desse modo, é a própria distinção ontológica entre realidade interior e exterior à mente, e o problema epistemológico em conceder objetividade a essas representações subjetivas, que Bergson tem como alvo e

\footnotetext{
${ }^{23}$ Bergson, H. 1999, p. 2.
} 
pretende solucionar com sua teoria da percepção, projeto que parece ser destacado com o termo "imagem" que, ao ser re-significado, a partir das significações que suscita para superar, aponta, ao mesmo tempo, o caminho a ser abandonado e o novo caminho a seguir.

Com efeito, se o termo "imagem" remete à teoria clássica da representação, no contexto da teoria da percepção de Bergson isso se faz para demarcar que tal representação é parte do representado (ainda que implique uma ação que não se explica nele e que, nesse sentido, aponta para uma realidade que o extrapola). Sendo assim, como afirma Worms, “chamar as coisas de imagens, não significa transformar o mundo em representação, mas, ao contrário, inscrever toda nossa representação, todas as características de nossa consciência, no mundo". ${ }^{24}$ Assim, se nossa percepção do mundo faz parte do mundo, ou seja, se o mundo é aquilo mesmo que é passível de ser percebido, em seu sentido mais estrito, abre-se para nós um campo de realidades que não se restringe aquele acessado pela nossa consciência, ainda que seja acessado diretamente por essa consciência: um campo transcendental de imagens.

Campo transcendental de imagens que, em última instância só reafirmará seu estatuto ontológico pela crítica posteriormente desenvolvida por Bergson em relação à postura metafísica que indevidamente põe a realidade de tal campo em suspeição. Quando Bergson então procurará defender a tese de que há um posicionamento teórico bastante identificável que nos leva a abandonar o ponto de vista do senso comum e então duvidar desse campo que se coloca por si, que extrapola nossa experiência e, no qual, entretanto, nossa experiência se dá. Por ora, Bergson pega a carona que o senso comum lhe oferece, e ao

\footnotetext{
${ }^{24}$ Worms, F. Le Vocabulaire de Bergson, Paris, Elipses, 2000, p. 30. “Assim, Bergson chama as coisas de imagens para enfatizar que todo conteúdo de nossa representação, inclusive as qualidades sensíveis aparentemente as mais relativas ao nosso espírito (cor, som, odor, etc.) faz parte integrante da matéria e do universo ("o objeto é, em si mesmo, pitoresco como o percebemos: é uma imagem, mas uma imagem que existe em si”, [Bergson, 1999, p. 2] ).”
} 
contrário de tirar o mundo de nossa experiência procurará mostrar como nossa experiência é que deve ser retirada do mundo por um processo de redução.

campo de imagens: determinação e indeterminação

Assim sendo, a própria definição desse campo de imagens define também um ponto de vista do qual se deverá partir. E, uma vez que tais imagens são caracterizadas pelas qualidades sensíveis e pela independência reputada ao mundo percebido nessas qualidades sensíveis pelo não-filósofo, trata-se de partir do ponto de vista desse não-filósofo. Mas, quem é esse não-filósofo e o que ele vê nesse mundo caracterizado qualitativamente e que subsiste por si mesmo? Em primeiro lugar esse homem é aquele que age no mundo e não se preocupa em teorizar à respeito da natureza daquilo sobre o que ele age. Se tal homem teoriza, é apenas para encontrar meios mais eficazes para agir. Sendo assim, quando nosso filósofo "ingênuo" entra a especular a partir da experiência desse homem de ação, tal marco zero não se identifica, de modo algum, com o ponto de vista de um sujeito em vias de formação e, concomitantemente, de uma experiência perceptiva também em formação. Trata-se, ao contrário, do ponto de vista de um homem que não acabou de surgir no mundo e que, portanto, pela experiência de ação que a própria sobrevivência sua e de sua espécie lhe concedeu, tem acumulado um saber que otimiza a eficácia dessa sua ação. Ele não apenas distinguiu fatos e objetos no mundo sobre o qual age, mas também foi capaz de formular leis que enunciam relações observáveis entre esses fatos e objetos. Ele organizou sua experiência sensível em ciência no sentido moderno dado ao termo. Este, com efeito, é o homo faber, que Bergson identifica tanto ao homem comum quanto ao homem de ciência, 
aquele que, a partir de sua percepção, desenvolve uma inteligência que o torna capaz de agir eficazmente sobre o mundo. Para Bergson, portanto,

\begin{abstract}
nossa inteligência é o prolongamento de nossos sentidos. Antes de especular é preciso viver, e a vida exige que tiremos proveito da matéria.(...) Bem antes que existisse uma filosofia e uma ciência, o papel da inteligência já era o de fabricar instrumentos e guiar a ação do nosso corpo sobre os corpos que nos circundam. A ciência levou esse trabalho da inteligência muito mais longe, mas não mudou a direção. (...) Mesmo quando especula, ela se preocupa ainda com agir, sendo o valor das teorias científicas sempre medido pela solidez do domínio da realidade que nos proporciona. ${ }^{25}$
\end{abstract}

No entanto, se o homem assim agiu e pensou foi porque, segundo Bergson, intuiu um conceito aplicável à realidade, o conceito de espaço — aquele de um meio homogêneo vazio que o "torna capaz de operar distinções nítidas, contar, abstrair e, quem sabe, até mesmo falar."26

Se, portanto, é do ponto de vista de um homem de ação, e de um homem de ciência — mais especificamente, de um mecanicista — que se inicia a análise de Bergson sobre os fatos envolvidos na percepção, é justamente a partir da caracterização desse ponto de vista como oriundo da espacialização que será possível delimitar seu raio de abrangência ao campo da praxis e, consequentemente, postular a existência de uma realidade mais complexa, à qual ele se aplica, mas que o excede; realidade que será objeto, portanto, de um conhecimento sui generis, livre dos esquemas e das exi gências nele vigentes.

Sendo assim, podemos dizer que o binômio determinação e indeterminação, detectado logo de início no campo de imagens no qual o filósofo "ingênuo" do primeiro parágrafo de Matéria e Memória se coloca, é a reedição da distinção, apresentada já no Ensaio, e fundamental para a totalidade do pensamento de Bergson, entre o ponto de vista

\footnotetext{
${ }^{25}$ Bergson, H. 1950, p. 34-35. “O Pensamento e o movente”. Trad. Franklin Leopoldo e Silva. In Bergson, São Paulo, Abril Cultural, 1979, p. 117-118 [col. Os Pensadores].

${ }^{26}$ Bergson, H. 1997, p. 73.
} 
da praxis e o da especulação teórica e, paralelamente, entre as partes da realidade que se prestam mais e aquelas que se prestam menos à espacialização.

No Ensaio, quando a análise dos dados da consciência revela, para Bergson, a duração, a espacialidade já aparece como aquele esquema que, adequadamente aplicado ao universo da matéria, com vistas à ação, deturpa a apreensão da natureza íntima da realidade dessa consciência. É de se notar, no entanto, que, ao mirar, em Matéria e Memória, a relação entre essa consciência e o universo material, a distinção, entre interior e exterior — na qual tal relação se resolvia aos olhos da teoria clássica da representação, e a qual, justamente, o observador bergsoniano deveria abstrair —, se vê substituída pela distinção determinação-indeterminação. Isso porque, aquilo que havia se mostrado como característica essencial da consciência, a saber, a duração, e a novidade ou indeterminação a ela inerente, se apresentará, também, no universo no qual essa consciência se insere — ou no qual ela surge —, uma vez que tal universo não se apresenta, em primeiro lugar, como o universo da matéria cartesiana cujas qualidades geométricas lhe concedem uma necessidade intrínseca, passível de cálculo e medição - matéria que, então, só ganharia colorido qualitativo quando reapresentada no interior de uma consciência - nem tampouco, em segundo lugar, como o universo exclusivo da matéria inanimada; mas como o universo de uma matéria em si qualitativamente caracterizada e, além disso, associada a um princípio de vida, fazendo parte, por isso, de um todo regido pela novidade e indeterminação.

Com efeito, se a realidade material, - que não mais será considerada como reapresentada na consciência, mas que compõe com ela um todo complexo — não é exclusivamente determinação e, portanto, universo por excelência da espacialidade, ela se deixa, no entanto, "moldar" por esta espacialidade com vistas à prática. Isso porque, pelo dualismo bergsoniano, a afirmação da realidade da matéria, e da consciência, passa 
justamente por uma distinção entre aquilo que existe, segundo um princípio de expansão constante, como profundidade, altura, largura, cor e textura, em outras palavras, aquilo que se dá em três dimensões, em uma duração que lhe é própria, e no sentido da expansão, por oposição aquilo que existe como princípio de contração e tensão, que organiza e cria. E, por isso mesmo, o dualismo bergsoniano distingue um aspecto da realidade mais concorde às exigências da espacialização e outro mais avesso a elas, sem, no entanto, deixar de considerar que a realidade é um todo complexo, e que só distinguimos suas partes por abstração.

Nesse sentido, é a distinção entre objeto da ciência e objeto da percepção - e o relativismo ou ceticismo então decorrente, dependendo do ponto de vista ao qual nos atenhamos — que se desloca para a distinção entre "indeterminado" e "orgânico", de um lado, e "determinado" e "inanimado", de outro; deslocamento que é o resultado de uma crítica à inteligência e à espacialização dela constitutiva, pois, segundo o ponto de vista de Bergson, por não "distinguir o inerte e o vivo, um adaptado de antemão ao quadro no qual o inserimos, o outro incapaz de nele se inserir a não ser por uma convenção que elimine o que lhe é essencial, nos vemos reduzidos a suspeitar igualmente de tudo o que o esquema contém. (...). Comecemos, ao contrário, traçando uma linha de demarcação entre o inerte e o vivo (...). ${ }^{, 27}$

Não se trata mais, portanto, de afirmar a distinção entre, de um lado, o mundo qualitativamente colorido da percepção e, por isso mesmo, subjetivo e existente apenas na interioridade de uma consciência e, de outro, o mundo real, composto de matéria e movimento e apreendido pela ciência segundo o modelo da matemática. Trata-se de observar que a matemática é apenas a explicitação, em sua forma mais pura, de um esquema comum tanto à percepção quanto à ciência, o esquema da espacialidade, montado pela

\footnotetext{
${ }^{27}$ Bergson, H. 1948, p. 208.
} 
inteligência, que decupa objetos e eventos, representa-os por palavras, agrupa-os em conceitos, e enuncia as leis pelas quais eles seriam regidos de modo determinado. Mas, tudo isso, abstraindo-se, em função da ação, uma parte constituinte da totalidade de uma realidade que, em evolução constante, não pode ser determinada.

É, portanto, essa crítica aos esquemas impostos pela inteligência, e, por ela, o desvelamento da inadequação da manutenção desse esquema quando se trata de conhecer a natureza como um todo, levando-se em conta, ainda, aquilo que remete à vida, ou ao princípio de ação, também característico do espírito e da consciência, que se leva a cabo, pela primeira vez, no Ensaio.

Com efeito, no Ensaio, só se chega à caracterização da consciência, como duração, após se ter feito a crítica à consideração da consciência como composta por estados distintos e justapostos. Estados que, observa então Bergson, só poderiam nos dar a multiplicidade do composto proveniente dessa sua justaposição — como o feixe de sensações de Hume —, ou nos remeter a unidade de uma consciência concebida como um receptáculo — o eu de Descartes -, mas a partir dos quais jamais poderíamos chegar a uma consciência caracterizada, a partir da experiência que dela temos, em sua verdadeira realidade que, para Bergson é, ao mesmo tempo, unidade e multiplicidade qualitativa.

No entanto, se a crítica à concepção da consciência a partir de seus estados distintos e justapostos se dá justamente, como sabemos, pelo desvelamento daquilo que Bergson define como a espacialização da consciência, esta espacialização é revelada por sua solidariedade com as matemáticas, mais especificamente, com o conceito de número, donde a importância da análise de tal conceito então efetuada. Por essa análise, Bergson pretende explicitar a equivalência da distinção entre a multiplicidade extensiva e intensiva e a distinção entre o espacial e o duracional, distinções que, de resto, reaparecerão no decorrer de sua obra 
caracterizadas como aquela existente entre o material e o vital, o orgânico e o inorgânico, ou, mais uma vez, entre o determinado e o indeterminado. Distinção que marca, por um lado, a justaposição de elementos com exterioridade recíproca e, por outro, a evolução pelo acréscimo contínuo de elementos que se fundem.

Assim, pela análise do conceito de número, (apresentada no Ensaio, ao tratar da espacialização da consciência), Bergson propõe que, se a realidade alcançada pelo aprofundamento da experiência da consciência se opõe àquela experiência superficial pela qual a consciência nos aparece decupada em estados, é porque estes são pensados à maneira de unidades numéricas, ou seja, como elementos com exterioridade recíproca que se justapõem - justamente o oposto da especificidade mesma da consciência que seria dada pelo imbricamento de estados qualitativamente caracterizados e que se transformam em outros numa evolução constante. Portanto, ao analisar o conceito de número, Bergson nos revela que sua matriz é o conceito de espaço, ou seja, a mesma matriz indevidamente aplicada à consciência e, nesse sentido, àquilo que é objeto atual ou possível da consciência perceptiva. Tal espacialização, portanto, está presente tanto na atuação do homem sobre o seu entorno, nas relações mantidas com seus semelhantes - estas, eminentemente marcadas pela linguagem - quanto na percepção que esse homem tem desse entorno e de si mesmo, uma vez que, tanto o universo percebido, quanto as emoções, paixões, ou chamados estados da alma que acompanham ou são causados por essa percepção, seriam encarados como unidades que se justapõem e, por isso mesmo, seriam quantificadas.

Se não, vejamos.

Tomemos os dois sentidos de unidade implícitos na definição de número da qual Bergson parte em sua análise: “Todo número é uma coleção de unidades (...) e, de outro lado, todo número é uma unidade em si mesmo, enquanto síntese das unidades que o 
compõem". ${ }^{28}$ Temos, assim, a unidade própria aos elementos que compõem o número considerado como uma coleção, e a unidade própria ao número considerado enquanto o resultado de uma síntese. Segundo Bergson, inicialmente consideramos a unidade dos elementos componentes do número como pura e simples e, nesse sentido, irredutível e definitiva; por oposição, consideramos a unidade que é o resultado da síntese dessas unidades "originais", justamente por ser derivada de uma soma, como apenas provisória e tomada de empréstimo do ato do espírito que a constitui.

No entanto, ao observarmos que também as unidades constitutivas dos números podem, tomadas fora do contexto da formação de determinado número, ser indefinidamente divididas, seríamos levados a concluir que toda unidade é constituída por um ato simples do espírito, aquele mesmo que se efetiva no momento da construção do número e que implica, portanto, uma multiplicidade sobre a qual ele se exerce. ${ }^{29}$ Com efeito, se, para efetuarmos a soma constitutiva de um determinado número, é preciso pensarmos as unidades que o compõem de forma definitiva; no entanto, a partir do momento em que não mais estamos levando em conta esta construção, tais elementos (unidades) ganham, nas palavras de Bergson, objetividade, transformam-se em coisas e, por isso mesmo, podem ser indefinidamente divididos. E transformam-se em coisas, ou são passíveis de divisão — o que para Bergson constitui o mesmo - porque a esse pensamento, ou intuição da unidade, é aplicado o esquema da espacialidade, pelo que, aquilo que era indiviso se divide em partes que se distinguem nitidamente umas das outras e, por isso mesmo, podem ser dadas simultaneamente por justaposição. Assim sendo, "não demoraremos a perceber que, se toda multiplicidade implica a possibilidade de tratar um número qualquer como uma unidade provisória que se uniria a si mesma, inversamente, todas as unidades, por sua vez, são

\footnotetext{
${ }^{28}$ Bergson, H. 1997, p. 59.

29 "No entanto, observando mais de perto, veremos que toda unidade é a de um ato simples do espírito, e que, uma vez que este ato consiste em unir, é preciso que alguma multiplicidade lhe sirva de matéria.” Bergson, H. 1997, p. 60.
} 
verdadeiros números, tão grandes quanto o queiramos, mas que consideramos como provisoriamente indecomponíveis para compô-los entre si. Ora, justamente porque admitimos a possibilidade de dividir a unidade em tantas partes quantas quisermos, a consideramos como extensa."30

Portanto, o número, tanto aquele resultante de uma soma quanto cada unidade que o compõe, é um misto de dois conceitos aparentemente auto-excludentes — unidade e multiplicidade - cuja origem Bergson trata de distinguir: de um lado, a intuição unificadora do espírito, de outro, a propriedade da divisibilidade, ou da justaposição simultânea, constituinte do conceito de um meio homogêneo ao qual tal intuição do espírito se aplica.

Aquilo que propriamente pertence ao espírito é o processo indivisível pelo qual ele fixa sua atenção sucessivamente sobre as diversas partes de um espaço dado; mas as partes assim isoladas se conservam para se unirem a outras e, uma vez adicionadas entre si, se prestam a qualquer tipo de decomposição: São, portanto, partes do espaço, e o espaço é a matéria com a qual o espírito constrói o número, o meio onde o espírito o coloca. ${ }^{31}$

Sendo assim, se a matemática é aplicável com sucesso ao universo dos objetos materiais, ou se os progressos da física-matemática são tão evidentes, é porque o mesmo esquema da espacialidade - aquele da justaposição de unidades com exterioridade recíproca - subjaz tanto à enumeração quanto à objetivação, e porque, de outro lado, a matéria seria mais suscetível a essa objetivação/enumeração do que, como afirma Bergson no Ensaio, os "estados puramente afetivos da alma ou, mesmo, àquelas representações que não as da visão e do tato" e, podemos acrescentar, a matéria seria mais suscetível à objetivação/enumeração do que aquilo que diz respeito ao ativo ou vital, ou do que a realidade considerada em seu todo.

\footnotetext{
${ }^{30}$ Bergson, H. 1997, p. 61.

${ }^{31}$ Bergson, H. 1997, p. 63.
} 
De qualquer forma, o certo é que tanto os objetos materiais quanto os números compõem aquela multiplicidade caracterizada pela justaposição de elementos com exterioridade recíproca, ou seja, caracterizada pela espacialidade, e que se opõe, no contexto do Ensaio, àquela "multiplicidade confusa das sensações e dos sentimentos, que apenas a análise distingue".

Nesse sentido, a convergência entre a objetivação e a enumeração aparece ainda na revelação de que a impenetrabilidade, comumente considerada, juntamente com a resistência e o peso, como uma das propriedades da matéria, seria, antes, uma propriedade do número. Com efeito, nos lembra Bergson, a impossibilidade de dois corpos ocuparem o mesmo lugar no espaço já está implícita na própria idéia do número 2 ou de qualquer outro número, uma vez que, na expressão "dois corpos” há a mesma idéia de duas posições no espaço presente na expressão "dois". Sendo assim, "se a impenetrabilidade passa quase sempre por uma qualidade da matéria, é porque consideramos a idéia do número como independente da idéia de espaço. Acreditamos então acrescentar algo à representação de dois ou vários objetos ao dizer que eles não podem ocupar o mesmo lugar: como se a representação do número dois, mesmo abstrata, não fosse, como já mostramos, a de duas posições diferentes no espaço! Afirmar a impenetrabilidade da matéria, é, portanto, simplesmente, reconhecer a solidariedade das noções de número e de espaço, é anunciar uma propriedade do número, mais do que da matéria."32

Assim sendo, a noção de corpo, objeto, ou de partes da extensão, equivale à noção de número, uma vez que tais noções se resumem a uma justaposição de elementos, que, por sua vez, nascem do conceito de divisibilidade, impenetrabilidade, exterioridade recíproca que são os tantos nomes dados àquela propriedade constitutiva do conceito de um meio vazio homogêneo que chamamos de espaço.

\footnotetext{
${ }^{32}$ Bergson, H. 1997, p. 66.
} 
Desse modo, a questão que versa sobre o caráter absoluto ou não do espaço — que, em sua formulação clássica, redundaria na questão sobre se o espaço está ou não contido no espaço — dá lugar à questão sobre a relação existente entre as qualidades dos corpos e o espaço que nossos sentidos percebem conjuntamente. ${ }^{33}$ Sendo assim, para Bergson, "a maior dificuldade parece ter sido a de esclarecer se a extensão é um aspecto das qualidades físicas — uma qualidade da qualidade — ou se essas qualidades são inextensas por essência e se o espaço viria se unir a elas, ainda que bastando-se a si mesmo e subsistindo sem elas."34

No caso da primeira hipótese, o espaço perderia realidade na medida em que seria o resultado da abstração daquilo que seria comum às ditas sensações representativas. No entanto, Bergson defende que a própria possibilidade da abstração implica o conceito de um meio homogêneo que possibilite as distinções nítidas e a exterioridade recíproca dos conceitos resultantes desse processo.

Com efeito, se, por um lado, o espaço não se sustenta mais como um lugar absoluto ocupado ou não por corpos, nem como a realidade extensa por excelência, ele tampouco é concebido por Bergson como uma abstração passível de ser feita a partir das qualidades sensíveis que compõem os corpos, ou ainda, como algo que surgiria da coexistência de várias qualidades inextensas, como propunham alguns fisiólogos do século XIX. ${ }^{35}$ Contra esta hipótese, Bergson observa que "as sensações inextensas permanecerão aquilo que elas são, a saber, inextensas, se nada se acrescentar a elas." E, na seqüência do mesmo raciocínio, afirma: "para que o espaço nasça de sua coexistência é preciso um ato do espírito que as abarque todas ao mesmo tempo e as justaponha"; já é preciso, portanto, a própria noção de espaço. Segue-se, então, a essas críticas, a comparação que não deixa de

\footnotetext{
${ }^{33}$ Cf. Bergson, H. 1997, p. 68.

${ }^{34}$ Bergson, H. 1997, p. 68.

${ }^{35}$ Hipótese defendida por fisiólogos como Lotze, Bain, Wundt e que são citados no Ensaio.
} 
causar um certo estranhamento: "esse ato sui generis se parece bastante com o que Kant chamou uma forma a priori da sensibilidade." 36

Com efeito, a hipótese apresentada na Estética Transcendental, pela qual, segundo Bergson, Kant teria garantido que o espaço "seria uma realidade tão sólida quanto as próprias sensações, ainda que de uma outra ordem."37, seria, para Bergson, a mais consistente. No entanto, sem considerar as relações de tal afirmação com o desenvolvimento posterior de seu pensamento, uma vez que para Kant, tal solidez se limita ao campo fenomênico e, para Bergson, tal solidez teria de estar fundada em uma realidade que o extrapola, salta aos olhos a distinção que se segue à concepção kantiana do espaço como uma forma da nossa sensibilidade, e a concepção bergsoniana do espaço como uma construção da inteligência. Com efeito, pela primeira, só há percepção no espaço, uma vez que toda percepção é, originalmente, intuição nas formas da sensibilidade, portanto, no espaço e no tempo. Pela segunda, abre-se, no entanto, a possibilidade de uma percepção não espacial, na medida mesma em que seja possível afastar os esquemas que a inteligência impõe à sensibilidade. Nesse sentido, ao conceber — ao contrário de Kant — o espaço como um conceito ou uma intuição proveniente apenas da inteligência e somente então aplicável às qualidades sensíveis — e, sendo assim, independente delas — ele confere a estas, agora, uma independência em relação ao espaço que não parece ser possível na concepção de Kant. Independência que, justamente, remeteria a uma realidade para além dos limites do campo fenomênico impostos pela teoria kantiana.

De qualquer forma, independentemente da sustentabilidade da interpretação da concepção de espaço kantiana proposta por Bergson, ou das diferenças entre as teorias dos dois filósofos, parece claro que o interesse de Bergson, ao se remeter a tal concepção, é

\footnotetext{
${ }^{36}$ Bergson, H. 1997, p. 70.

${ }^{37}$ Berg son, H. 1997, p. 69.
} 
justamente o de resgatar a afirmação da existência independente do espaço — portanto, o fato deste não ser considerado como um conceito oriundo da abstração ou da justaposição das qualidades sensíveis — sem ter de assumir uma formulação clássica dessa independência, ou seja, de um espaço como realidade absoluta, como lugar dos objetos físicos, como realidade da matéria, com todos os problemas então decorrentes.

Independência do espaço em relação às qualidades sensíveis que se remete, para Bergson, a um ato do espírito "que consiste, essencialmente, na intuição, ou, sobretudo, na concepção de um meio vazio homogêneo." ${ }^{38}$ De tais considerações segue-se, para Bergson, necessariamente, a seguinte definição do espaço.

Pois não há outra definição possível de espaço: aquilo que nos permite distinguir várias sensações idênticas e simultâneas umas das outras; portanto, um princípio de diferenciação que não aquele da diferenciação qualitativa e, consequentemente, uma realidade sem qualidade. ${ }^{39}$

No entanto, o que entender por "sensações idênticas e simultâneas"? Se há identidade qualitativa não haveria uma só sensação? À primeira vista somos levados a pensar que, se há justaposição, é porque há limites qualitativos que nos fazem pensar em dois e não em um. Mas justamente o que Bergson vem defendendo até aqui é que as distinções qualitativas não se dariam na forma de elementos com exterioridade recíproca, mas como uma continuidade que evolui como duração; e que, portanto, aquilo que faz com que dividamos o fluxo qualitativo em coisas que então são passíveis de serem consideradas simultaneamente por justaposição é precisamente a capacidade de "interpretar essa diferença de qualidade como uma diferença de situação", para o que é preciso que tenhamos "a idéia clara de um meio homogêneo, quer dizer, de uma simultaneidade de termos que,

\footnotetext{
${ }^{38}$ Bergson, H. 1997, p. 70.

${ }^{39}$ Idem, ibidem.
} 
idênticos em qualidade, se distinguem, no entanto, uns dos outros. ${ }^{40}$ Assim, para Bergson, quanto mais insistirmos na heterogeneidade das qualidades percebidas, mais afirmamos a ação do espírito que impõe a forma da homogeneidade extensa a essa heterogeneidade qualitativa.

No entanto - e aqui, no âmbito do Ensaio, já se esboça a distinção com Kant que só se aprofundará no posterior desenvolvimento do pensamento de Bergson - existiria nas próprias qualidades percebidas uma extensão real pela qual elas ocupariam determinada posição, de preferência a outra, ao serem inseridas no esquema da espacialidade. Nesse sentido, haveria uma extensão própria às qualidades sensíveis que não aquela representada pelo meio vazio homogêneo concebido pelo espírito; extensão que, de resto, possibilitará a radical distinção efetuada em Matéria e Memória entre a teoria da percepção ali desenvolvida e as teorias da representação, bem como das metafísicas subjacentes a estas teorias. Com efeito, em Matéria e Memória, tal distinção será aprofundada em relação àquela presente no Ensaio, uma vez que a teoria ali desenvolvida defenderá que as qualidades percebidas são percebidas nos objetos, e não produzidas nas consciências e, nesse sentido, serão dotadas de uma extensão que, no entanto, não pode ser essa extensão geométrica que caracteriza o espaço vazio homogêneo. O problema então ganhará outro foco, o de saber como as qualidades que estão no mundo passam a ser qualidades para uma consciência, e como, de resto, essa consciência se forma sem se tornar ela mesma extensa, ou como ela se diferencia da extensão então percebida. Problemas que de verão passar pela concepção da memória para serem então resolvidos.

É assim que, no Ensaio, Bergson encerra a discussão sobre a natureza do espaço supondo que "se a representação de um espaço se deve a um esforço da inteligência, inversamente, deve haver nas próprias qualidades que diferenciam duas sensações uma

\footnotetext{
${ }^{40}$ Bergson, H. 1997, p. 71.
} 
razão em virtude da qual elas ocupam, no espaço, esta ou aquela posição determinada", pelo que seria "preciso, portanto, distinguir entre a percepção da extensão e a concepção do espaço”. Suposição que ele procurará fundamentar e dela tirar suas conseqüências metafísicas no primeiro e quarto capítulos de Matéria e Memória e que se manterá, como atesta a seguinte passagem de $O$ Pensamento e o movente:

Se a inteligência é feita para utilizar a matéria, sua estrutura, sem dúvida, está modelada pela matéria. (...) É impossível considerar o mecanismo de nossa inteligência, e também o progresso de nossa ciência, sem concluir que entre a inteligência e a matéria há, efetivamente, simetria, concordância, correspondência. De um lado, cada vez mais a matéria se resolve, aos olhos do cientista, em relações matemáticas e, de outro, as faculdades essenciais de nossa inteligência somente funcionam com precisão absoluta quando se aplicam à geometria. ${ }^{41}$

Frisemos, portanto que, paralelamente à solidariedade que aqui é traçada entre a espacialização e a matemática, a concepção de objeto e de número, traça-se também a solidariedade entre esse universo da determinação e aquilo que poderíamos chamar de a parte extensa da realidade, aquela dada nas qualidades sensíveis, e que, por essa mesma solidariedade, se distinguiria da realidade característica da vida, que estaria na origem da própria representação, da consciência ou, ainda, do universo da indeterminação. No entanto, essa mesma vida gera, também como consciência, uma capacidade de adaptação à realidade que tende a desconsiderar sua indeterminação característica e vai se moldando e desenvolvendo a partir da consideração preferencial daquilo que pode ser determinado. Tal capacidade é o que, segundo Bergson, chamamos de inteligência.

E o que é essa inteligência? Para Bergson "a maneira humana de pensar. Ela nos foi dada, como o instinto à abelha, para dirigir nossa conduta. Uma vez que a natureza nos destinou a utilizar e a dominar a matéria, a inteligência só evolui com facilidade no espaço e

\footnotetext{
${ }^{41}$ Bergson, H. $1950 / 1979$, p. $35 / 118$.
} 
só se sente à vontade no domínio do inorganizado. Originalmente ela destina-se à fabricação; manifesta-se por uma atividade que prefigura a arte mecânica e por uma linguagem que anuncia a ciência — tudo o mais na mentalidade primitiva é crença e tradição. O desenvolvimento normal da inteligência efetua-se, pois, na direção da ciência e da técnica."

Sendo assim, tanto o ponto de vista da percepção quanto o da ciência são resultado da espacialização efetivada pela inteligência e constituem um conhecimento "aproximativo" da matéria; a percepção, "subordinada às exigências práticas, efetua distinções muito nítidas na matéria, passíveis constantemente de revisão", a ciência, "aspirando à forma matemática, acentua a espacialidade da matéria, mostrando esquemas sempre superáveis”, mas, ambas, "versam sobre a realidade".

No mesmo sentido em que afirmou a espacialidade subjacente ao ponto de vista do senso comum e da ciência, à percepção de objetos e às abstrações realizadas a partir dessa percepção no sentido das generalizações permitidas pela radicalização, e não pelo abandono, da perspectiva espacial sobre a realidade, Bergson caracterizou os processos indutivos e dedutivos — que, à primeira vista, teriam matrizes distintas —, e explicitou, a partir dessa caracterização, a equivalência entre ambos e, portanto, entre o raciocínio calcado na experiência, com os graus de incerteza que dela provêm, e aquele calcado na certeza matemática, ideal da ciência moderna.

Com efeito, no Ensaio, quando Bergson faz a crítica à coisificação da alma e, com ela, a crítica à possibilidade de considerar os atitudes futuras determinadas de antemão nas condições presentes, ou seja, de considerar os eventos psíquicos como regidos pelo princípio de causalidade, Bergson constrói uma tipologia da causalidade calcada nas diferentes formas de considerá-la, como um processo indutivo ou dedutivo.

\footnotetext{
${ }^{42}$ Bergson, H. $1950 / 1979$, p. 84/144.
} 
Tal caracterização, dos processos indutivos e dedutivos, é retomada por Bergson em Evolução Criadora, no bojo mesmo de sua distinção entre os domínios da inteligência e da ciência, por um lado, e da intuição e da metafísica, por outro, ou seja, da consideração, em um outro contexto, da distinção, apresentada no primeiro parágrafo de Matéria e Memória, entre o universo passível de ser apreendido segundo leis necessárias e aquele que, por princípio, é indeterminação.

Nesse contexto, Bergson inicia suas considerações sobre o raciocínio dedutivo apresentando-o como modelo da relação existente entre a definição das figuras geométricas e suas determinações, mesmo aquelas apenas posteriormente explicitáveis. ${ }^{43}$ Assim, Bergson observa:

quando traço grosseiramente sobre a areia a base de um triângulo e começo a formar os dois ângulos nessa base, sei de um modo certo e compreendo absolutamente que, se esses dois ângulos são iguais, os lados também o serão (...). ${ }^{44}$

E, mais, sei isto antes de me instruir em qualquer possível geometria científica; tais propriedades se impõem a partir de minha ivência tátil e visual da imagem formada no espaço, como conseqüências cuja "evidência e clareza ultrapassam as das outras deduções." 45

De fato, a dedução, presente na geometria científica, e que expressaria a determinação de todos os teoremas relativos a uma figura em sua definição, seria de mesmo tipo daquela presente na "geometria natural" implicada nas ações do homem sobre o mundo à sua volta; ambas seriam imagens de "relações de determinação necessária, graças a

\footnotetext{
${ }^{43}$ Cf. Bergson, H. 1948, p. 212. Bergson, H. A Evolução Criadora. Trad. Bento Prado Neto, São Paulo, Martins Fontes, 2005, p. 230: "O mesmo movimento pelo qual eu traço uma figura no espaço engendra-lhe as propriedades; estas são visíveis e tangíveis nesse mesmo movimento; eu sinto, eu vivo no espaço a relação da definição com suas conseqüências, das premissas com a conclusão."

${ }^{44}$ Idem, ibidem.

${ }^{45}$ Idem, ibidem.
} 
premissas que contêm, por antecipação, sua conclusão". Duas imagens de implicação necessária que estariam fundadas, por sua vez, no caráter quantitativo, explícito em uma e implícito na outra, de suas premissas e conclusões, isto porque os teoremas geométricos seriam apenas a formulação quantitativa das relações envolvendo grandezas e situações detectadas pela inteligência humana já nas primeiras questões práticas com as quais ela se deparou. Nesse sentido, nota Bergson, "o selvagem é melhor que o civilizado na avaliação de distâncias, na determinação de uma direção, em retraçar de memória o esquema frequentemente complexo do caminho percorrido e voltar assim, em linha reta, para seu ponto de partida". ${ }^{46}$

Desse modo, se posteriormente esta geometria natural se desenvolverá pela álgebra, é porque as características das figuras percebidas pelos sentidos são passíveis de serem quantificadas, ou antes, porque aqui "estamos no domínio da quantidade pura e, uma vez que as propriedades geométricas podem ser postas na forma de igualdades, é fácil entender que uma primeira equação, que exprima a propriedade fundamental da figura, se transforme em uma multiplicidade indefinida de equações novas, virtualmente contidas naquela." ${ }^{47}$

Por outro lado, o raciocínio indutivo, não mais aplicável a figuras geométricas, mas a eventos no mundo físico, funda-se na crença de que determinados efeitos seguem-se de determinadas causas, ou seja, funda-se no princípio de causalidade. Causalidade que tanto pode ser entendida, à maneira dos empiristas, como uma conjunção constante entre eventos que, por isso mesmo, não fundamenta nenhuma relação intrínseca entre esses eventos, e é, nesse sentido, apenas uma constatação, índice de probabilidade e não portadora de certeza; quanto pode ser entendida à maneira do senso-comum, que, segundo Bergson, ao interpretar a associação subjetiva existente entre a percepção de um evento e a idéia de um evento

\footnotetext{
${ }^{46}$ Bergson, H. 1948/2005, p. 212/ 230.

${ }^{47}$ Bergson, H. 1997, p. 153.
} 
subseqüente como uma relação objetiva entre dois eventos, acredita que há, efetivamente, uma pré-formação dos eventos futuros nas condições presentes, o que possibilitaria, pelo conhecimento de todas as condições presentes (ainda que tal conhecimento se mantenha apenas como um ideal), a determinação absoluta do futuro.

No entanto, Bergson também nota que, se tal relação de determinação necessária é legítima no universo das matemáticas - no qual, por exemplo, podemos observar o engendramento conjunto das figuras geométricas de todas as suas propriedades ou a préexistência dos teoremas na definição dessas figuras — isso se dá pela espacialidade a ele inerente e, apenas nesse sentido, é passível de ser transposta para o universo dos fenômenos físicos.

Sendo assim, a crença do senso comum na necessidade de tal conexão só se sustenta porque está assentada em três outras crenças, que implicam a transposição de outras três características do universo da matemática — ou da espacialidade — para o dos fenômenos físicos.

Tratemos da primeira, aquela da possibilidade de isolamento, para fins práticos, de um grupo de eventos em um sistema que então seria completado pelos eventos que a ele devem se seguir. Bergson nos apresenta como exemplo o sistema formado pelos elementos água-panela-fogareiro. Assim, a elevação da temperatura da água até sua ebulição, após um determinado tempo, estaria relacionada apenas à fonte de calor emitida pelo fogareiro, não tendo sido levado em consideração nenhum elemento exterior a esse sistema o que, certamente, implicaria uma cadeia de reações dificilmente determinada em seus limites últimos. Dado o fogareiro e a sobreposição, sobre sua chama, de uma panela com água, seguir-se-á, necessariamente, após um determinado tempo, a ebulição da água. Esse recorte de um microcosmos no interior de uma realidade que contém um número indefinido de 
elementos mimetiza aquele sistema fechado e completo da figura geométrica que, por sua vez, é reduzível ao sistema fechado e completo dos números, ou seja, aquele, segundo o qual, dados determinados elementos, necessariamente estão dados também outros determinados elementos que, assim, completam o sistema: "Se ponho dois números, com efeito, já não sou mais livre para escolher sua diferença. Se parto de dois lados de um triângulo e do ângulo circunscrito, o terceiro lado surge por si mesmo, o triângulo completase automaticamente." ${ }^{48}$ Trata-se, portanto, do ideal do sistema fechado da geometria e da álgebra, no qual todos os elementos estão dados a priori, que se sustenta em maior ou menor grau na crença da pré-formação dos fenômenos físicos futuros nas condições presentes. ${ }^{49}$ Com efeito, acreditamos que, se nossas induções falham, isto não se deve a um erro inerente ao raciocínio - a uma impossibilidade de circunscrever um sistema fechado — mas a uma falha em elencar os elementos envolvidos nele.

No entanto, como subjacente a essa crença, há ainda a crença na possibilidade de sobreposição dos sistemas assim isolados, ou seja, de que aquelas condições que se apresentam hoje, podem ser sobrepostas àquelas que ocorreram ontem, donde se seguiriam as mesmas conseqüências, necessariamente. Sobreposição que, mais uma vez, só é possível em um universo imaginado como semelhante ao da geometria, e para o qual, notemos agora, o tempo não existe - no qual, portanto, a definição-premissa seria simultânea às propriedades-conclusões — ou em um universo no qual o tempo fosse abstraído. Mas, e o que mais nos interessa aqui, tal construção e sobreposição de sistemas inerentes à indução implicam ainda a crença mais fundamental de que qualidades possam se sobrepor como quantidades.

\footnotetext{
${ }^{48}$ Bergson, H. 1948/2005, p. 216/234.

${ }^{49}$ Cf. Bergson, H. 1997, p. 153-157, “Toda relação de determinação necessária estabelecida entre fenômenos sucessivos segue-se de que percebemos, ainda que de modo confuso, um mecanismo matemático por trás dos fenômenos heterogêneos."
} 
Pois, como a análise dos números explicitou, somente o que é considerado igual a si mesmo pode ser acrescentado a si mesmo, à maneira da evolução que chamamos de escala dos números ou quantificação. Por sua vez, algo idêntico a si mesmo só pode se distinguir de si mesmo e, assim, ser acrescentado a si mesmo, pela diferença de lugar ocupado, o que pressupõe uma justaposição ou simultaneidade de elementos, ou, como vimos, o espaço. Portanto, a espacialidade que está subjacente às deduções matemáticas está também subjacente à indução pela qual orientamos nossa ação no universo físico.

Nossas induções são certas, aos nossos olhos, na exata medida em que fundimos as diferenças qualitativas na homogeneidade do espaço que as subtende, de modo que a geometria é o limite ideal de nossas induções, tanto quanto de nossas deduções. O movimento ao termo do qual está a espacialidade deposita ao longo de seu trajeto a faculdade de induzir assim como a de deduzir, a intelectualidade inteira." 50

Nesse sentido, ainda, Bergson explicita a relação, característica da filosofia cartesiana, entre a distinção da natureza da matéria e aquilo que dela é percebido e o ideal de conhecimento certo - que remete ao universo matemático e, portanto, à espacialização. Com efeito, para erigir uma ciência certa da matéria foi preciso superar a dificuldade em declarar equivalentes aqueles eventos físicos que se distinguem qualitativamente, tanto quanto pela quantidade. Sendo assim, as diferenças qualitativas foram retiradas da matéria e consideradas como impressões por ela causada em nossos sentidos. Para além da heterogeneidade qualitativa de nossas sensações, supôs-se então a verdadeira realidade física como uma extensão homogênea, como um espaço decupado em figuras geométricas, que teriam, então, as leis de suas propriedades e de seus movimentos contidas nelas $a$ priori. E será então pela forma, posição e movimento dessas figuras que se explicará a multiplicidade de sensações que seriam suas qualidades apenas aparentes. Mas Bergson

\footnotetext{
${ }^{50}$ Bergson, H. $1948 / 2005$, p. 217/235-6.
} 
nota ainda que mesmo a representação do universo físico por meio de figuras, seria, se levássemos tal raciocínio ao extremo, insustentável, uma vez que, se a posição e o movimento integram o universo das grandezas e das variações entre elas, as figuras, enquanto temos dela uma representação visual, mantêm-se como aquela qualidade que introduz incerteza no sistema. Assim, seria preciso desconsiderar até mesmo essa forma sensível da figura e considerar apenas a fórmula abstrata pela qual tal figura é construída. Nesse sentido

\begin{abstract}
se a matéria se reduz, como quer Descartes, a uma extensão homogênea, os movimentos das partes dessa extensão podem ser concebidos pela lei abstrata que os preside ou por uma equação algébrica entre grandezas variáveis, mas não se representar na forma concreta de imagens. E poderíamos provar sem dificuldade que, quanto mais o progresso das explicações mecânicas possibilitam o desenvolvimento dessa concepção de causalidade e, consequentemente, aliviam o átomo do peso de suas propriedades sensíveis, mais a existência concreta dos fenômenos da natureza tendem a se esvair em fumaça algébrica. ${ }^{51}$
\end{abstract}

Para Bergson parece então evidente que o empobrecimento do universo físico de suas qualidades sensíveis e, mais do que isso, a teoria que se segue a esse empobrecimento, ou seja, que nega nosso acesso direto ao universo físico então geometrizado, e pela qual temos acesso direto apenas a uma representação desse universo, têm sua origem no ideal de certeza, ou determinação necessária, imposto à realidade pelo esquema da espacialização criado por nossa inteligência com vistas à ação.

Sendo assim, podemos concluir que, para Bergson, a atuação do espírito, na percepção, ao isolar ou discernir objetos no fluxo da realidade material e, na ciência, ao constituir um sistema fechado que descreva as relações e os fatos concernentes a esses objetos; ao considerar que tais eventos e relações se repetem, e ao considerar, portanto, as distinções qualitativas como distinções quantitativas, anulando qualquer atuação de uma

\footnotetext{
${ }^{51}$ Bergson, H. 1997, p. 156.
} 
temporalidade real, caracteriza-se pela aplicação de um esquema. Tal esquema Bergson identifica a própria espacialidade; tal atuação do espírito, Bergson identifica à inteligência humana. Nesse sentido, ainda, ele aproxima os processos de indução, que regem nossas ações no mundo e os processos científicos de base empírica, ao da dedução, ideal de uma ciência que se pauta pela matemática, descrevendo-os de forma a demonstrar que ambos, e não apenas o processo dedutivo, têm como limite ideal a geometria, ou o reino da necessidade: determinação. Nesse sentido, ainda, por ser tal determinação fruto da aplicação de um esquema à realidade, ele acredita poder afirmar que essa mesma realidade permanece, ao mesmo tempo, prestando-se a essa determinação e extrapolando-a como criação constante: indeterminação.

Voltemos, portanto, ao universo de imagens diante do qual nosso observador se postou e à indeterminação, nele detectada, a partir da ação de algumas imagens — cujo exemplo me é dado pelo meu corpo - em meio à necessidade que regula a influência das demais imagens entre si.

A que imagens, no entanto, Bergson está se referindo? Inicialmente, como supusemos até aqui, aquilo que é acessado pelos sentidos, mas cuja influência recíproca fosse detectada, para além da minha ou da sua percepção, por um ponto de vista objetivo. Assim, parece se configurar, aqui, a concepção de uma ciência universalizante ou objetivante que seria a depuração dos pontos de vista particulares ou subjetivos, dados na percepção individual, no sentido do estabelecimento de relações constantes a partir da experiência vivida, as chamadas leis da natureza. Tal conjunto de imagens que aparecem regidos pela necessidade da lei não se opõem, portanto, a um conjunto de imagens dado na percepção, mas parecem apenas organizá-lo a partir da abstração e da generalização. Assim, com efeito, os princípios indutivos e dedutivos se mostrarão análogos, um não se regerá por 
uma essência matemática do universo e outro por uma redução à empiria, mas ambos comungarão da espacialização a qual determinadas imagens tenderiam, mas que só será efetivada pela atuação do intelecto. Portanto, se há uma distinção nesse campo de imagens do qual se partiu, esta não é aquela existente entre a percepção e uma suposta realidade subjacente acessada pela ciência, como a proposta pelo realismo cartesiano. A distinção que se fundaria, segundo Bergson, no interior mesmo do campo de imagens inicialmente posto, seria aquela que separa, de um lado, as imagens passíveis de serem relacionadas por essas leis necessárias e, por outro, aquelas que não se prestam a tanto. Estas, imagens que, tomando como exemplo meu próprio corpo, e que logo se mostrarão identificadas a todo corpo vivo, se regram por relações que não podem ser totalmente determinadas a priori. E se tal indeterminação é detectada quando eu me volto para aquelas imagens que têm como modelo o meu corpo, o qual, além de ser percebido — apreendido do exterior, como os demais objetos e, nesse sentido, constituinte do universo da percepção tanto quanto do universo da ciência — é também apreendido do interior, é para esse corpo próprio que se volta nossa atenção.

o corpo próprio

Continuemos, portanto, a análise desse campo de imagens proposto por Bergson, a partir da análise dessa imagem especial — meu corpo — que se destaca das demais por ser objeto também de afecção e pelo tipo especial de ação que parece estar relacionada a essa afecção. 
A configuração desse corpo, a partir do estudo de corpos semelhantes, apresenta-se como a de um sistema centrado, mais especificamente, como um conjunto de nervos aferentes que transmitem os estímulos recebidos dos demais corpos, pelos nervos sensíveis, até um centro nervoso, e um conjunto de nervos eferentes que partem desses centros nervosos e transmitem estímulos até os nervos motores que efetivamente colocam em movimento partes ou todo o corpo.

Não se trata de avaliar o grau de sofisticação da descrição do mecanismo sensório-motor apresentada por Bergson. O que importa, aqui, é o nível em que a discussão está se desenvolvendo. Sendo assim, o fato de uma investigação que tem como objetivo analisar o processo da percepção, começar pela descrição da fisiologia de um corpo, portanto, de um conteúdo dessa mesma percepção, sem, de antemão, definir o estatuto desse conteúdo através de uma crítica prévia pela qual fosse possível auferir critérios da realidade desses conteúdos perceptivos, pareceria, no mínimo, ingênuo. No entanto, tal ponto de partida é totalmente proposital e se insere no contexto da hipótese — que se está testando — de que tanto a matéria quanto a representação da matéria — ou seja, a matéria percebida — fazem parte de uma mesma realidade. Sendo assim, tanto aquilo que diz respeito aos nervos que compõem a fisiologia do sistema sensório-motor, quanto ao meu corpo ou os corpos que o circundam, fazem parte, por hipótese, da mesma realidade, e realidade cuja apreensão não implicaria nenhuma duplicação. Com efeito, para Bergson, a hipótese que se está testando se opõe justamente a esta outra hipótese segundo a qual apreendemos o mundo material por meio de impressões produzidas, a partir dele, em uma mente e, portanto, que a representação deste mundo material, nessa mente, seria uma duplicação que diferiria, por natureza, da realidade material fora da mente — donde a necessidade de critérios de adequação entre realidade e representação. Para Bergson, ao contrário, é 
somente porque assumimos tal hipótese que seríamos levados a colocar em dúvida a realidade daquilo que é conteúdo da percepção e, nesse sentido, do corpo próprio e de seus processos fisiológicos. E mais, para Bergson, supomos muito quando assumimos tal hipótese, mais, talvez, do que poderíamos comprovar, seja por fatos, seja pela própria lógica, uma vez que mesmo as teorias clássicas da representação devem partir da análise de fatos, portanto de conteúdos da percepção, e seguir as regras da lógica.

Com efeito, pela análise das relações observáveis entre meu corpo e os corpos que o circundam, Bergson procurará mostrar que a interpretação dos fatos aí envolvidos pelas teorias da representação implica erros lógicos

Teoria da representação que estaria pressuposta na interpretação do mecanismo sensóriomotor apresentada por psicólogos e fisiólogos, quando estes afirmam que, a partir da transmissão de estímulos da periferia do corpo até o cérebro, ocorre, nesse centro nervoso, a transformação desses estímulos em imagem, ou seja, mais propriamente, em representação daquelas imagens — agora no sentido bergsoniano - que comporiam o universo. De fato, quer a tese da equivalência entre o estado psíquico e o estado cerebral defenda que o estado psíquico é uma simples decorrência de um estado cerebral, ou que ambos, estado psíquico e cerebral são a reproduções distintas de um mesmo original, portanto, que não há uma mecanismo de causação entre ambas, de qualquer modo que tal equivalência seja apresentada, ela nunca questionará o pressuposto segundo o qual conhecer o mundo material pelos sentidos é conhecer o mundo material por estados psíquicos por ele causados e, nesse sentido, perceber o mundo material em uma mente, e não nele próprio. 
No entanto, antes de criticar a teoria da representação em sua economia interna, Bergson aponta para a contradição, na qual ela está assentada em suas várias vertentes e que, como dissemos, se explicita na interpretação do mecanismo sensório-motor.

Tal interpretação apresenta-se contraditória, se nos mantivermos na hipótese de Bergson, que supõe serem imagens tanto o corpo próprio, incluindo todo o sistema nervoso e o próprio cérebro, quanto os corpos exteriores a esse corpo, uma vez que, aqueles, como imagens, não poderiam, por isso, dar de si nada mais do que o conteúdo que as constitui e as distingue das demais. Para tanto, teríamos de supor que todo o universo estaria contido nessas imagens, o que se configura como o erro lógico de se tomar a parte pelo todo, uma vez que é patente ser meu corpo quem faz parte do conjunto das imagens, e não o contrário.

No entanto, tal caracterização do meu corpo e dos corpos circundantes como imagem, ou seja, como algo que não possui um "fundo falso" ou quaisquer virtualidades, presta-se também, nesse sentido, para refutar as teorias da representação que sustentam uma concepção idealista da matéria, uma vez que a identificação da matéria à representação, pelo idealismo, tem em comum, com a hipótese de Bergson, justamente a negação de uma realidade subjacente a essa matéria-representação.

Se, no entanto, não podemos supor encontrar nessas imagens aquilo que não está nela, não poderíamos imaginar que tais imagens tivessem o poder de reproduzir as imagens que lhe são exteriores? Tal objeção, com efeito, não poderia ser feita a Bergson por um realista que não tem qualquer compromisso com a hipótese da matéria-imagem de Bergson e que concede à matéria justamente a virtualidade de produzir impressões sensíveis? 
Ocorre que Bergson procurara demonstrar que a contradição identificada na hipótese idealista atinge igualmente a hipótese realista e, mais do que isto, que ambas hipóteses incorrerem também no erro lógico de não se manterem fiéis as premissas das quais partiram.

Sendo assim, o caráter aparentemente prosaico da refutação do idealismo fundada na impossibilidade lógica de que o todo esteja contido em uma de suas partes, ganha maior relevância quando observamos que, em última instância, tal refutação recairá também sobre o realismo. Isso porque, toda vez que, assumindo uma posição realista, afirmamos que a matéria age sobre um composto de duas substâncias distintas — matéria e espírito (corpo e alma) - , causando nele representações, e que tal ação atinge o elemento espiritual por meio do elemento material que a ele está indissoluvelmente ligado, e, além disso, localizamos e descrevemos nessa matéria, que então é chamada de corpo, partes e mecanismos de atuação, estaremos tratando esse corpo e, portanto, essa matéria, não como realidade oculta por trás de representações, mas como a própria representação. Estaremos, portanto, sendo idealistas e, no que se refere à produção de representação por esse corpo, incorrendo no erro de incluir o todo na parte.

Tal argumento é explicitado em "O Cérebro e o pensamento", 52 quando Bergson justamente insiste na impossibilidade, não somente do realista, mas também do idealista em manter-se em apenas uma posição quando se trata de afirmar a tese do paralelismo psicofisiológico que, como defendemos, tem como fundamento a teoria da representação da realidade material no interior de uma mente.

\footnotetext{
52 "O Cérebro e o Pensamento: Uma Ilusão Filosófica", in Bergson. Seleç. Franklin Leopoldo e Silva, trad. Franklin Leopoldo e Silva e Nathanael Caxeiro. São Paulo, Abril Cultural, 1979 [col. Os Pensadores].
} 
Com efeito, se o idealista ${ }^{53}$, ao afirmar a correspondência entre os estados cerebrais e os estados psíquicos não se detém diante do abs urdo de afirmar que a parte contém o todo, é porque imperceptivelmente já assumiu o ponto de vista realista, ou seja, já não mais considera o cérebro, como parte, como representação entre representações, mas como uma realidade com virtualidades — no caso, o poder de engendrar representações considera, portanto, o cérebro como a matéria do realista.

Por outro lado, se o realista ${ }^{54}$, ao afirmar o paralelismo entre as séries físicas e psíquicas identifica no cérebro centros de fala, de memória, etc., é porque está considerando o cérebro como eficaz em seu detalhamento, e, nesse sentido, está considerando o cérebro segundo o ponto de vista do idealista, pois, ao conferir eficácia àquelas articulações dadas na percepção sensível, portanto, próprias de uma representação, as está considerando como reais. Paradoxalmente, no entanto, ao conceder ao cérebro uma eficácia virtual ele o está considerando como coisa e, nesse sentido, voltando a ser realista.

Sendo assim, a teoria que pressupõe que estados físicos do cérebro têm correspondência com estados psíquicos — hipótese operacional necessária para uma teoria que defende a representação mental dos objetos físicos, que poderiam, assim, se dar por meio desse mecanismo cerebral — não se sustenta porque, na mesma argumentação, considera o

\footnotetext{
${ }^{53}$ Cuja posição Bergson define da seguinte forma no referido artigo: "Para o idealista nada mais há na realidade além do que aparece à minha consciência ou à consciência em geral. Seria absurdo falar de uma propriedade da matéria que não se pudesse tornar objeto de representação. Não há virtualidade ou, ao menos, nada de definitivamente virtual nas coisas. Tudo o que existe é atual ou poderá tornar-se atual. Em suma, o idealismo é um sistema de notação implicando que todo o essencial da matéria é mostrado ou mostrável na representação que dele temos, e que as articulações do real são as mesmas de nossas representações." Idem, p. 44.

${ }^{54}$ Cuja posição Bergson define do seguinte modo no artigo citado: "O realismo repousa na análise inversa. Dizer que a matéria existe independentemente de nossa representação é pretender que sob nossa representação da matéria há uma causa inacessível dessa representação, que por trás da percepção do atual há poderes e virtualidades ocultos: é, enfim, afirmar que as divisões e articulações visíveis em nossa representação são puramente relativas à nossa maneira de perceber." Idem, ibidem.
} 
físico — no caso, o cérebro — ora como psíquico (representação) ora como material (coisa).

Sendo assim, Bergson resume:

\begin{abstract}
Falava-se primeiro do cérebro tal como o víamos, tal qual o destacávamos do conjunto de nossa representação: ele era apenas uma representação e estávamos no idealismo. A relação do cérebro ao restante era, então, repetimos, da parte com o todo. Disso passamos bruscamente para uma realidade que seria subjacente à representação: seja, mas então ela é subespacial, o que significa que o cérebro não é uma entidade independente. Só há, agora, a totalidade do real incognoscível em si, sobre o qual se estende a totalidade da nossa representação. Estamos no realismo; e, tanto nesse realismo quanto no idealismo de há pouco, os est ados cerebrais não são o equivalente da representação (...) Mas eis que, quando se trata do detalhe do real, continuamos a compô-lo da mesma maneira e segundo as mesmas leis da representação, o que equivale a não destingui-los um do outro. Voltamos, pois, ao idealismo, e nele deveríamos permanecer. Mas não. Conservamos realmente o cérebro tal como ele é representado, mas esquecemos que, se o real está desdobrado na representação, estendido nela, e não contraído nela, ele não pode mais encerrar as virtualidades de que falava o realismo; erigimos, então, os movimentos cerebrais em equivalentes de toda a representação. Oscilamos, pois, do idealismo ao realismo e do realismo ao idealismo, mas tão rapidamente que nos acreditamos imóveis e, de alguma forma, o cavaleiro dos dois sistemas reunidos em um só. Esta aparente conciliação de duas afirmações inconciliáveis é a própria essência da tese do paralelismo" ${ }^{55}$
\end{abstract}

Assim, para Bergson, não podemos sustentar a hipótese do paralelismo entre os estados psíquicos que nos dariam a representação do mundo material e determinados estados corpóreos porque caímos na contradição de considerar uma mesma realidade segundo dois conceitos excludentes. Com efeito, consideramos a matéria como aquilo que podemos perceber pelos sentidos quando definimos que ao estado de determinada parte do cérebro, que tem forma, cor, peso, etc., corresponde, por exemplo, a capacidade específica da articulação da linguagem. No entanto, ao mesmo tempo, consideramos a matéria como uma realidade subjacente àquilo que podemos perceber pelos sentidos, uma vez que, não podendo determinar, a não ser a posteriori, como tal conjunto de forma, peso, cor, reações químicas e correntes elétricas, etc. se relacionam com nossas aptidões de linguagem, com nossas sensações, com nossas lembranças, etc., somos obrigados a supor, nessa mesma matéria, um manancial de potencialidades.

Demonstrada a contradição inerente ao paralelismo psicofisiológico, ou à hipótese segundo a qual determinados movimentos ocorridos no cérebro poderiam engendrar

\footnotetext{
${ }^{55}$ Idem, p. 50.
} 
estados psíquicos, mais especificamente, estados que representariam aquele universo material que, em contato com o meu corpo haviam causado tais movimentos e, consequentemente, tais representações, afasta-se a hipótese de que meu corpo seja sede de representação, mantendo-se, no entanto, sua descrição como centro de recepção e devolução de movimento. Nesse sentido, "meu corpo, objeto destinado a mover objetos é, portanto, um centro de ação, não poderia fazer surgir uma representação". ${ }^{56}$

Afastada a hipótese de o corpo — enquanto centro de ação — produzir representação, é preciso explicitar como, a partir da análise dessa ação, podemos compreender o processo em que essa representação se dá.

Levando em conta, portanto, a hipótese que se acredita comprovada pela experiência, ou seja, que meu corpo é uma imagem capaz de exercer uma ação "real e nova" sobre as imagens que estão a sua volta, e que essa "influência real" se caracteriza por aquilo que a distingue da necessidade reinante na relação entre as demais imagens, ou seja, se define por sua indeterminação, segue-se que tal ação se distingue das demais justamente porque implica um leque de possibilidades de escolha que, como observa Worms, é "condição ao mesmo tempo lógica e cronológica da ação real". ${ }^{57}$ No entanto, como se trata de um organismo vivo, que tende a se preservar, esta escolha não pode ser pura. Ela deve se pautar pela vantagem que esse organismo puder retirar das demais imagens circundantes, donde se segue que, de algum modo, estas devem exibir-lhe as faces das quais tais vantagens poderão ser retiradas.

\footnotetext{
${ }^{56}$ Bergson, 1999, p. 14.

57 Worms, F. 1997, p. 31.
} 
Assim, as imagens circundantes ganham, com a delimitação dessas faces, o aspecto de objetos, pelo qual, a partir do corpo próprio, são consideradas em sua utilidade; ainda que percam, por não serem consideradas, no campo representativo que então se engendra, as demais relações ou faces pelas quais interagem com o todo das imagens. No entanto, a ação apenas possível só pode se dar porque se conseguiu levar em conta um objeto de ação não iminente, e que, justamente por isso, está à distância do centro da ação que, então, pode ser postergada. Sendo assim, é por essa correspondência entre a distância e a possibilidade de ação entre uma imagem referência e as demais imagens que é "montado" o espaço circundante da representação, que se estende desde um horizonte visual esmaecido até o limite da ação real, equivalente à uma sensação tátil.

Nesse sentido ainda, as diferentes qualidades pelas quais os objetos se apresentam para um corpo em constante movimento são prova da relação estabelecida entre a distância que separa este corpo e os demais corpos — ou seja, entre a iminência ou não da ação desse corpo em relação aos demais — e o desenho da percepção. "De fato, observo que a dimensão, a forma, a própria cor dos objetos exteriores se modificam dependendo da aproximação ou do distanciamento de meu corpo, que a força dos odores, a intensidade dos sons aumentam e diminuem com a distância, enfim, que essa distância representa, sobretudo, a medida na qual os corpos circundantes estão de algum modo assegurados contra a ação imediata de meu corpo." 58

Postula-se, assim, como explicação para o engendramento da representação uma hipótese que leve em conta apenas as imagens e as ações observadas entre elas.

As imagens que estão sob a iminência da ação de meu corpo apresentam-se mais destacadas e em um horizonte reduzido; aquelas em relação às quais a ação de meu corpo se

\footnotetext{
${ }^{58}$ Idem, p. 15.
} 
faz esperar, apresentam-se com menos destaque em um horizonte ampliado e, assim, as demais características constituintes do campo da representação podem, por hipótese, relacionar-se com a prontidão da ação e se escalonarem, ao redor do centro de onde esta ação emana, de acordo com essa prontidão ou força. O que explicaria porque "à medida que meu horizonte se amplia, as imagens que me circundam parecem se desenhar sobre um fundo mais uniforme e se tornar indiferentes para mim. Quanto mais recuo esse horizonte, mais os objetos que ele circunscreve se escalonam distintamente segundo a maior ou menor facilidade de meu corpo em tocá-los e movê-los. Eles devolvem ao meu corpo, como faria um espelho, sua eventual influência; se ordenam segundo o poder crescente ou decrescente do meu corpo." 59

Sendo assim, os mesmos fatos que eram interpretados como índice da subjetividade das qualidades sensíveis e, por isso, da distinção de natureza entre essas qualidades e a coisa à qual elas remeteriam, podem agora ser interpretados num mesmo plano de realidade, o das imagens, levando-se em conta apenas a ação de uma imagem especial, que se apresenta como ponto de referência, a as imagens que, a partir dessa ação, o circundam. Agora, portanto, os objetos exteriores ao meu corpo não são reapresentados no interior de uma consciência, mas sua representação se desenha neles mesmos, refletindo a ação possível de meu corpo sobre eles. ${ }^{60}$

Em resumo, a constante mutabilidade do espaço da representação se explica pela própria dinâmica que produz este espaço. Dinâmica que, por não implicar apenas as ações atuais entre as imagens que o compõem, mas a possibilidade de tais ações, recorta, do universo das imagens, um conjunto de imagens que são objeto de ação possível de uma imagem referência.

\footnotetext{
${ }^{59}$ Bergson, H. 1999, p. 15.

${ }^{60}$ Idem, p. 16.
} 
Compreendendo desse modo a relação existente entre o meu corpo e o engendramento do espaço da representação ou da percepção dos "corpos" exteriores, isto é, que minha percepção desenha precisamente no conjunto das imagens, como uma sombra ou um reflexo, as ações virtuais ou possíveis de meu corpo ${ }^{61}$ - sem, portanto, considerar meu corpo como fonte de representação —, se pode explicar, ainda, como as alterações ocorridas nele correspondem a alterações de minha percepção do universo das imagens - do espaço da representação.

Com efeito, segundo essa hipótese, se eu seccionasse todos os nervos aferentes do sistema cérebro-espinhal, mesmo que as demais imagens não fossem por isso modificadas, como também o restante de meu corpo, no entanto, se interromperia $a$ corrente que vai da periferia à periferia passando pelo centro e toda a minha "percepção" dessas imagens desapareceria. Aparentemente, no entanto, tal experiência daria razão à hipótese contrária, que sustenta que a percepção se forma no cérebro, uma vez que essa percepção desaparece quando o caminho pelo qual se transmitia a ação exterior sobre ele foi rompido. Mas o que Bergson deseja mostrar, remetendo-se a esse aparente contra-exemplo, é que tal experiência também seria compreensível segundo sua hipótese, uma vez que, ao seccionar os nervos que trazem os impulsos até o centro nervoso, impossibilitou-se justamente a ação de meu corpo sobre essas imagens, que não mais poderia buscar, no meio das coisas que o circundam, a qualidade e a quantidade de movimento necessárias para agir sobre elas. Conseqüentemente, o leque de possibilidades de ação que se apresentava ao meu corpo reduz-se a nada, pois, uma vez que o próprio mecanismo que possibilitava o adiamento da ação, e que era responsável, portanto, por sua indeterminação, foi interrompido, não há mais ação apenas possível,

\footnotetext{
${ }^{61}$ Idem, ibidem.
} 
não há mais escolha. Meu corpo continua recebendo e exercendo influência das imagens que o circundam sem, no entanto, estabelecer uma relação de distância com estas imagens, sem poder, assim, postergar uma ação que se apresenta em uma gama de possibilidades de ação, sem poder exercer esta ou aquela ação, indeterminadamente.

Essa experiência limite é apresentada, na verdade, como contraprova de que meu corpo é um centro de ação entre imagens, e não uma fonte de produção ou de reprodução de imagens, e reforça a concepção de que é possível explicar a distinção observada entre o que chamamos de matéria e percepção da matéria apelando apenas para um campo objetivo pré-dado — que equivale à matéria justamente porque constitui-se como uma totalidade que, enquanto totalidade, é imperceptível por definição — e um tipo de ação que se exerce no interior dessa campo a partir de um elemento especial nele inserido. Desse modo, a percepção ganha objetividade, porque é parte de um campo dado, e ganha subjetividade porque é parte destacada a partir e para um determinado elemento desse campo. E, nesse sentido, percepção e matéria devem diferir sempre, ainda que a relação entre ambas esteja desde o início garantida pela ação pela qual uma só pode se engendra a partir da outra.

Donde as duas definições: Chamo de matéria o conjunto de imagens, e de percepção da matéria essas mesmas imagens relacionadas à ação possível de uma certa imagem determinada, meu corpo. ${ }^{62}$

\footnotetext{
${ }^{62}$ Bergson, 1999, p. 17.
} 
Dá-se então a distinção entre a matéria e sua percepção sem caracterizar essa percepção como conteúdo produzido no interior de uma consciência previamente dada, mas a percepção será definida juntamente com a consciência, ${ }^{63}$ por meio da circunscrição de um campo a partir da abrangência de um centro de ação. Obviamente, portanto, dá-se a percepção sem caracterizá-la como algo interior a uma consciência, ou como estado de uma consciência. E dá-se a distinção entre a matéria e sua percepção ao mesmo tempo em que se estabelece o caráter subjetivo e objetivo dessa percepção. Certamente existem dois pólos já definidos, aquele do campo das imagens e o da ação indeterminada que nele se imiscui com o surgimento dos corpos vivos — nada que não possa ser resolvido, justamente, em termos de ação e imagens. No entanto, se é preciso encontrar o lugar da consciência nesse universo, não poderá ser pela consideração dessa consciência como substrato da percepção, uma vez que a percepção está inscrita nas coisas. Ora, ocorre que parece ser justamente esse vício de querermos encontrar a percepção em uma consciência aquilo que nos impede de ver que, ao destacar um campo de imagens a partir de um centro que envolve ação e escolha sobre essas imagens, tanto a percepção quanto seu caráter consciente já estão dados. Sendo assim, para explicitar o lugar demarcado da consciência desde o momento em que a indeterminação é constatada no universo das imagens, não antes nem depois, Bergson continuará testando sua hipótese sobre a percepção, baseado agora nas definições provisórias que relacionam essa percepção a um campo objetivo pré-dado e a um tipo de ação especial nele detectado.

\footnotetext{
${ }^{63}$ Bergson, H. 1999, p. 35: "Nossa representação da matéria é a medida de nossa ação possível sobre os corpos; resulta da eliminação do que não diz respeito às nossas necessidades e funções. [...] A consciência — no caso da percepção exterior - consiste precisamente nessa escolha.”; Bergson, H. 1948, p. 145: “A consciência é a luz imanente à zona de ações possíveis ou de atividade virtual que circunda a ação efetivamente realizada pelo ser vivo. Ela significa hesitação ou escolha.".
} 
Com efeito, ao se aprofundar na análise dessas definições, Bergson não poderá deixar de detectar a mesma relação entre as alterações ocorridas no interior do corpo próprio, mais especificamente, no seu centro nervoso, e a percepção do que é exterior a esse corpo. "Modifique os objetos, modifique a relação deles com o meu corpo, e tudo se modifica nos movimentos interiores de meus centros perceptivos. Mas tudo se modifica também em 'minha percepção'. Minha percepção é, portanto, função desses movimentos moleculares, ela depende deles. Mas depende como?" ${ }^{64}$ Certamente, no entanto, ele não poderá interpretar tal relação segundo a hipótese do paralelismo psicofisiológico, uma vez que, como notamos acima, ao considerar a percepção como a tradução daquilo que ocorre nos centros nervosos, cairíamos ou na contradição de esperar que a tradução da parte pudesse nos dar a tradução do todo; ou na contradição de tomar esse centro nervoso em duas acepções divergentes, ora como semelhante, em natureza, àquelas representações das coisas por ele mesmo engendradas — uma vez que tal centro nervoso é tomado em sua configuração espacial —, ora como coisa — realidade subespacial, com poderes e virtualidades —, porque capaz de causar essas representações e, nesse sentido, distinto delas por natureza.

Se, para Bergson, nos deparamos com todo tipo de problema ao tentar fazer surgir a variedade de nossa representação dos movimentos detectados em um grupo particular de imagens, por outro lado, estes mesmos movimentos — livres da suposição de que possam engendrar representação — são claros em si mesmos e em sua função de "preparar, dando-lhe início, a reação de meu corpo à ação dos objetos exteriores" e ao esboçar, nessa preparação, todos os possíveis caminhos de reação que, estes sim, equivalem ao

\footnotetext{
${ }^{64}$ Bergson, H. 1999, p. 17.
} 
meu espaço de representação (campo perceptivo): este agora o problema da hipótese de Bergson.

Nesse sentido, o cérebro e a medula espinhal, constituídos, ambos, de matéria nervosa, seriam responsáveis pela transmissão e composição de movimentos, o que significa que as funções do cérebro e da medula não seriam de naturezas diferentes, mas apenas de graus distintos de complexidade. Com efeito, a observação também nos mostra que as ações-reflexo comandadas pela medula seguem-se imediatamente a uma excitação sofrida, enquanto as reações comandadas pelo cérebro, pela própria sofisticação de sua estrutura e pela infinidade de caminhos que suas inumeráveis ramificações oferecem aos estímulos nervosos, podem ser inibidas ou postergadas. E justamente essa capacidade de recuar diante de uma reação imediata e, nesse sentido, potencializar a indeterminação dessa reação, capacidade que teria chegado ao grau máximo, por nós detectado, com o surgimento, na série dos organismos vivos, da estrutura complexa do cérebro, parece dar a Bergson aquilo que ele precisa para caracterizar a relação entre o que ocorre no cérebro e a representação. Pois, uma vez que os movimentos que ocorrem no cérebro são o esboço das possíveis ações do meu corpo a partir dos estímulos vindos do exterior — estímulos que, uma vez alterados, causam alteração nos movimentos cerebrais - e, uma vez constatada a relação entre a amplitude e complexidade do espaço da representação e a variação das possibilidades de ação e, conseqüentemente, da indeterminação da ação, segue-se que esses movimentos cerebrais são, ao mesmo tempo, o vetor, pelo qual se recorta no universo das imagens um espaço de representação, e a referência pela qual o corpo do qual eles fazem parte se orienta nesse espaço assim constituído. Sendo assim, "eles marcam a todo momento, como faria uma bússola que movimentamos, a posição de uma determinada imagem, meu corpo, em relação às imagens circundantes. No conjunto 
da representação são bem pouca coisa; mas têm uma importância capital para essa parte da representação que eu chamo de meu corpo, pois esboçam, a todo momento, a possibilidade de seus passos."65

Tal hipótese está longe de ser inquestionável, mas, certamente tem a seu favor o fato de se basear em um ponto pacífico, uma vez que "como todos concordam, as vibrações cerebrais fazem parte do mundo material, e que tais imagens, conseqüentemente, ocupam apenas uma parte extremamente pequena da representação", ${ }^{66}$ não podendo, portanto, sob pena de contradição, traduzir-se no todo da representação.

Se, com efeito, a tentação permanece e nela caem muitos filósofos é porque, segundo Bergson, ao considerar a percepção como a tradução das modificações sofridas pelo cérebro, considera-se esse cérebro em situação de isolamento. No entanto, tal posição de isolamento assumida pelo cérebro, para além da insustentabilidade de supor um objeto caracterizado sensorialmente como destacado dos demais objetos que o circundam, aponta também para a insustentabilidade da decisão teórica de recuar diante de uma presença, a própria presença do mundo (ou do conjunto das imagens), do qual o cérebro (uma imagem) faz parte. É, efetivamente, pela possibilidade de desconsiderar a realidade da totalidade daquilo que se apresenta (em sentido forte), e na qual o cérebro está inserido, que se aventa a possibilidade de que seria através de uma interioridade, que de alguma forma teria de ser "tocada" do exterior, por meio do cérebro (parte da presença descartada e que, curiosamente, se mantém), que poderíamos chegar a construir isto que então se apresenta (em sentido fraco), e que seria entendido, agora, como duplicação de algo que existiria em uma exterioridade; exterioridade cuja realidade, portanto, alcançaríamos apenas indiretamente, ou, mesmo, jamais poderíamos alcançar.

\footnotetext{
${ }^{65}$ Bergson, H. 1999, p. 19.

${ }^{66}$ Bergson, H. 1999, p. 18.
} 
No entanto, a relação entre a recusa de uma presença e a teoria da representação da realidade da matéria na realidade pensante, criticada por Bergson, não poderia ser uma das formas de, justamente, caracterizar a filosofia de Descartes? Com efeito, se Descartes não foi o primeiro a colocar em dúvida a realidade do mundo, e se também não foi o primeiro a afirmar a certeza de um ser pensante em meio a tantas incertezas, certamente foi ele quem, ao fazer desse ser pensante a primeira certeza a partir da qual se garantisse a certeza de tudo o mais, fez também desse ser pensante, além de fundamento da certeza da realidade material, o substrato da representação dessa realidade, o próprio sujeito da representação. Assim, a realidade do mundo passa a se fundamentar na evidência da existência do ser pensante e nas verdades que, por sua vez, se fundamentam nessa primeira evidência e que levam esse ser a acreditar na existência dessa realidade como distinta dele mesmo e representada, nele mesmo, por meio de impressões e idéias. Fundase, então, a relação entre a interioridade de uma consciência, identificada, como Bergson sugere, a um "receptáculo vazio", e a exterioridade de uma "matéria sem forma" que, por uma ação incompreensível" produziria, nessa consciência, sua representação, ou o mundo assim como o conhecemos pelos sentidos.

Paradoxalmente, no entanto, a presença do mundo se dissipa, e só será possível acessá-lo como idéia, sensível ou inteligível. Sendo assim, como o mundo não se põe mais como presença, é o eu, com a própria evidência de sua existência, com sua capacidade de intuir, raciocinar e sentir que põe o mundo real e vivido.

No entanto, mesmo fazendo a apologia da força da presença do mundo, seria difícil descartar totalmente a hipótese que põe em dúvida tal presença, personificada, por Descartes, no gênio maligno, uma vez que, tendo a capacidade de reproduzir diante de mim o objeto sem que ele esteja efetivamente presente, nada poderia me garantir que não 
estou diante de uma reprodução todas as vezes que eu acredito estar em presença de um objeto. Mas é preciso nos lembrarmos ainda que, para Descartes, as impressões dos sentidos, que correspondem a um objeto exterior, não se distinguem, por sua natureza, das idéias da imaginação, que não têm como correspondente qualquer objeto exterior atual, uma vez que ambos são estados de uma mente - indistinção de natureza entre percepção e alucinação que constituiria toda a força da hipótese do gênio maligno. Para Bergson, ao contrário, há uma distinção de natureza entre o objeto que se apresenta a mim, uma vez que ele é parte do mundo material, e a manutenção desse objeto na memória, quando então ele passaria a fazer parte daquela realidade, distinta da material e constituinte da consciência.

De qualquer modo, se a força da presença do mundo e, mesmo, a suspeita de que uma certa fraqueza da vontade poderia ser responsabilizada pela criação de hipóteses como a do gênio maligno, podem não ser suficientes para convencer um espírito cartesiano, Bergson ainda tem como recurso, para defender sua hipótese, demonstrar a contradição que envolve a hipótese oposta. O que ele espera ter feito ao denunciar o caráter incompreensível das virtualidades que essa hipótese tem de conceder à matéria (razão pela qual, ainda, para Bergson, a hipótese, da qual ele parte, da identificação da matéria a um campo de imagens é bastante mais plausível do que esta de um poço de virtualidades). Ou ainda, ao denunciar as contradições em que incorre quando procura explicar tal ação inexplicável por meio da intermediação, também inexplicável, da parte desse mundo sensível mais estreitamente unida à consciência, o corpo próprio. Contradição na qual os psicólogos e fisiólogos contemporâneos a Bergson caíram, mas que já estava antecipada em Descartes como se comprova pelas suas considerações sobre a união do corpo e do espírito, bem como suas considerações sobre a atuação do cérebro 
ou, mais especificamente, da glândula pineal, no processo das sensações. Pois, ainda que Descartes afirme que não é possível compreender pelo entendimento a forma pela qual a alma está unida ao corpo, a idéia de sua união é fornecida pela nossa natureza e garantida pelo entendimento e, nesse sentido, garantida também "a força que a alma tem de mover o corpo (...) e do corpo agir sobre a alma, causando-lhe seus sentimentos e paixões."67

Assim, se Descartes afirma que as sensações, como a de fome, sede, dor, etc. nada mais são "que maneiras confusas de pens ar que provêm e dependem da união e da mistura entre o espírito e o corpo" e que "o espírito não recebe imediatamente a impressão de todas as partes do corpo, mas somente do cérebro, ou talvez, mesmo, de uma de suas partes, a saber, aquela onde se exerce a faculdade que chamam o senso comum, a qual todas as vezes que está disposta da mesma maneira, faz o espírito sentir a mesma coisa"; ou seja, se, para Descartes, somos uma substância resultante do composto entre a substância alma e a substância corpo, e se, sendo assim, o corpo age sobre a alma e a alma age sobre o corpo e, mais, se os sentimentos e paixões são causados por determinados movimentos detectados no cérebro, e as sensações impressas na imaginação a partir da presença dos corpos exteriores, não seria lícito supor que tais corpos exteriores atuem sobre o corpo próprio que, então, à maneira dos sentimentos e das paixões, suscitaria as idéias sensíveis?

No entanto, não é preciso ir tão longe. Basta que Descartes tenha afirmado que percebemos a matéria por meio de idéias sensíveis (e conceber essas idéias como particulares, estados de uma mente) e que somos um misto de matéria e espírito, para que o engendramento de tais idéias tenha de passar pela matéria à qual estamos jungidos e

\footnotetext{
${ }^{67}$ Descartes, R. “Carta a Elisabeth”, 21-05-1643, in Descartes, Intr. Gilles-Gaston Granger, Pref.e notas Gerard Lebrun, Trad. J Guinsburg e Bento Prado Jr. São Paulo, Abril Cultural, 1983 [col. Os Pensadores]: “e, enfim, as coisas que pertencem à união da alma e do corpo não são conhecidas senão obscuramente pelo entendimento só, ou mesmo pelo entendimento com a ajuda da imaginação; mas são conhecidas muito claramente pelos sentidos."
} 
para que, então, a denúncia de contradição que Bergson endereçava à hipótese do paralelismo psicofisiológico recaia também sobre Descartes.

Assim, a hipótese da percepção proposta por Bergson, e que se segue a essa crítica parece ganhar força, por um lado, ao apresentar a relação existente entre o cérebro e a percepção em outros termos - para Bergson, mais inteligíveis e, nesse sentido, constituindo um ganho teórico em relação à hipótese criticada — ou seja, não mais como aquela relação que se expressa pela intermediação necessária de um elo contraditório entre uma ação incompreensível de uma matéria sem forma sobre um pensamento sem matéria. Ao contrário, não sendo a percepção o resultado da relação de produção, por parte dos movimentos cerebrais isolados, de um mundo paralelo no interior de uma mente, é na própria relação estabelecida entre esses movimentos cerebrais e seu entorno, portanto, no próprio mundo do qual ele faz parte, que tal percepção se dá. Sendo assim, bastaria negar a posição de isolamento do cérebro, de resto insustentável, em relação ao que lhe é circundante, para que o campo perceptivo se estabelecesse justamente como aquele recorte na totalidade do conjunto das imagens/mundo, campo perceptivo (ou espaço de representação) que varia de amplitude de acordo com a variação de quantidade e qualidade dos movimentos que essa sua parte que chamamos de corpo próprio consegue buscar nele. Sendo assim, ao afirmar a presença do mundo e, nesse sentido, negar a hipótese da produção da representação de um mundo exterior em uma interioridade e, com isso, negar, além da duplicação do mundo material, por sua representação, também o dualismo nos termos de uma interioridade inextensa e de uma exterioridade extensa, a hipótese proposta por Bergson evitaria o esvaziamento da realidade objetiva dessa representação (a percepção), mantendo, com isso, a matéria nela circunscrita (representada) ao alcance de nossa mão. 
É assim que, segundo a hipótese de Bergson, que parte de um campo de imagens identificado à matéria e no qual a representação da matéria se dará por uma "escolha" de determinadas imagens a partir de um centro definido pelas características de sua ação entre essas imagens, e, portanto, no qual a representação da matéria é pensada em termos da ação, a questão sobre a realidade dessa representação em torno da qual se debatiam idealistas e realistas não tem mais lugar de ser, e é substituída pela questão sobre como ambas posições subsistem num mesmo universo dado.

E subsistem, primeiramente, porque ao retirar-lhes o pressuposto epistemológico do qual partiam perdem suas conotações metafísicas. Com efeito, para o idealista, que considera a representação sob o ponto de vista da subjetividade, ela consistiria em todo acesso fidedigno que podemos ter do universo material, quando não se identifica propriamente com esse universo. Para o realista, ao contrário, que, em nome da objetividade, se coloca no ponto de vista de uma matéria subjacente a essa representação, tal representação é um acesso que, apesar de não poder ser dispensável, é um conhecimento deturpado da matéria e que deve ser superado em nome de outro mais fidedigno.

No entanto, para Bergson, essa incompatibilidade entre os pontos de vista idealista e realista, se deve justamente ao fato de, tanto idealistas quanto realistas, encararem a percepção — de onde um e outro têm necessariamente de partir — como conhecimento, ou seja, uma representação da realidade material, fidedigna ou não, que não está inserida nessa matéria, mas que, como conhecimento, é idéia, pensamento, sensação e, nesse sentido, faz parte de uma consciência.

No entanto, uma vez que a representação não mais é considerada em função do conhecimento que nos daria da realidade, mas de uma ação que se exerce na matéria, sua própria realidade não está em questão e não precisa ser fundada por nenhuma adequação 
àquilo que ela representa. Sendo assim, idealismo e realismo não se afirmariam mais como posições epistemológicas distintas que poderiam fundamentar posições metafísicas também distintas como o espiritualismo, de um lado, e o materialismo, de outro. Segundo a hipótese de Bergson, idealismo e realismo não se excluem como duas formas de acesso à realidade, mas se opõem como dois pontos de vista sobre uma mesma realidade, a do conjunto das imagens.

No entanto, se, em Matéria e Memória, o realismo e o idealismo são considerados como dois pontos de vista sobre a realidade equivalentes a dois sistemas que coexistiriam nessa realidade, segundo o espaço centrado da percepção ou o espaço neutro da ciência, o aprofundamento da análise de tais relações levou Bergson a redimensioná-las.

Retomemos então essas relações assim como elas foram estabelecidas em Matéria e Memória. De um lado, o realismo, que, ao identificar a realidade da matéria ao universo da ciência - aquele das imagens que se relacionam entre si num espaço homogêneo segundo leis necessárias - deve partir desse universo para dele derivar a percepção; de outro, o idealismo que, ao identificar a realidade com o universo inerente a uma subjetividade aquele das imagens que organizam no entorno de uma imagem especial - deve partir desse universo para deduzir o universo da ciência. Sendo assim, cada posição, apesar de partir, em suas análises, da percepção, que ambos consideram como "conhecimento", desenvolverão suas doutrinas sustentando posições distintas e auto-excludentes sobre o estatuto desse conhecimento perceptivo em relação ao conhecimento científico. Se o conhecimento é aquilo que me revela a realidade, e se eu tenho duas formas de conhecimento e uma única realidade, segue-se, necessariamente que apenas uma forma de conhecimento é fidedigna. Assim, para o realista, o conhecimento da realidade fornecido pela percepção é múltiplo, confuso, provisório e necessariamente distinto das identidades captadas com clareza e 
distinção pelo conhecimento científico na direção do qual ele deve ser superado. Por outro lado, para o idealista, as percepções nos dão a realidade, apenas esquematizada e simbolizada pela ciência. Portanto, teríamos, de um lado, a concepção realista da matéria estreitamente ligada à ciência e a concepção idealista da matéria ao mundo perceptivo.

Ocorre, no entanto, que em "O Cérebro e o pensamento" é o ponto de vista idealista sobre o universo que nos cerca que se vê estreitamente relacionado ao conhecimento científico, enquanto o realismo apontaria para uma visão metafísica das coisas.

Vejamos como isso se dá. Em primeiro lugar retomemos a definição de idealismo e realismo propostas em "o Cérebro e o Pensamento":

\begin{abstract}
Para o idealista nada mais há na realidade além do que aparece à minha consciência ou à consciência em geral. Seria absurdo falar de uma propriedade da matéria que não pudesse se tornar objeto de representação. Não há virtualidade ou, ao menos, nada de definitivamente virtual nas coisas. Tudo o que existe é atual ou poderá tornar-se atual. Em suma, o idealismo é um sistema de notação implicando que todo o essencial da matéria é mostrado ou mostrável na representação que dele temos, e que as articulações do real são as mesmas de nossas representações. (...) O realismo repousa na análise inversa. Dizer que a matéria existe independentemente de nossa representação é pretender que sob nossa representação da matéria há uma causa inacessível dessa representação, que por trás da percepção do atual há poderes e virtualidades ocultos: é, enfim, afirmar que as divisões e articulações visíveis em nossa representação são puramente relativas à nossa maneira de perceber. ${ }^{68}$
\end{abstract}

As definições ora propostas explicitam a contradição inerente à variação entre dois pontos de vista que se querem excludentes e nos chama a atenção para algo que anteriormente ficara escamoteado. Ou seja, ao definir o ponto de vista idealista, em última instância, como aquele segundo o qual "o essencial da matéria é mostrado ou mostrável na representação que dela temos, e que as articulações do real são as mesmas de nossas representações" ao mesmo tempo em que se afirma a identidade entre a percepção e a matéria e portanto a realidade de nossa percepção, expressa-se também a lógica pela qual o

\footnotetext{
${ }^{68}$ Bergson, H. 1979, p. 44.
} 
discurso científico se estrutura. Pois é evidente que, mesmo que o ponto de vista científico se outorgue a ruptura, na captura da realidade, com aquilo que ele reputa como percepções subjetivas dessa realidade, e que, portanto, ele considere essa realidade subjacente a nossa percepção como um poço de virtualidades — numa clara posição realista — ele não pode descrever o mundo a partir dessas virtualidades, mas ele o faz, destacando conteúdos (construindo objetos) e descrevendo as relações entre estes conteúdos assim destacados no modo explícito das representações, portanto, numa clara posição idealista. É nesse sentido que a ciência — ou aquele ponto de vista supostamente realista — só pode se exercer segundo o ponto de vista idealista. ${ }^{69}$

Assim, prossegue Bergson:

\begin{abstract}
Aprofundando os dois sistemas, veríamos que o idealismo tem por essência se deter no que está dado no espaço e nas divisões espaciais, enquanto o realismo tem estes dados por superficiais e estas divisões por artificiais: ele concebe, por trás das representações justapostas, um sistema de ações recíprocas, e, consequentemente, uma implicação das representações umas nas outras. Como, por outro lado, nosso conhecimento da matéria não pode derivar inteiramente do espaço, e como a implicação recíproca de que se trata, por mais profunda que seja, não se pode tornar extra-espacial sem tornar-se extra -científica, o realismo não pode ultrapassar o idealismo em suas explicações. Estamos sempre mais ou menos no idealismo (tal como o definimos) quando somos cientistas: caso contrário, não pensaríamos sequer em considerar partes isoladas da realidade para condicioná-las umas em relação às outras, o que constitui a própria ciência. A hipótese do realismo não é mais que um ideal destinado a lembrar-nos que nunca aprofundaremos suficientemente a explicação da realidade, e que deveremos estabelecer relações cada vez mais íntimas entre as partes do real que se justapõem, a nossos olhos, no espaço. ${ }^{70}$
\end{abstract}

No limite, portanto, o ponto de vista realista, que de início se distinguia do ponto de vista idealista por afirmar a existência de uma realidade subjacente àquela dada na

\footnotetext{
69 "Mas a verdade é que o realismo jamais se mantém em estado puro. Podemos pôr a existência da realidade em geral por trás da representação: quando começamos a falar de uma realidade em particular, queiramos ou não, fazemos com que a coisa coincida mais ou menos com a representação que temos dela. Sobre o fundo da realidade oculta, onde tudo está necessariamente implicado em tudo, o realismo desdobra as representações explícitas que são para o idealista a própria realidade. Realista ou idealista no momento em que põe a realidade, ele torna-se idealista quando afirma qualquer coisa sobre ela, pois a notação realista apenas pode consistir nas explicações de detalhe, em inscrever sob cada termo da notação idealista um sinal que assinala seu caráter provisório.” Bergson, H. 1979, p. 49.

${ }^{70}$ Bergson, H. 1979, p. 50.
} 
percepção, ao procurar se aproximar dessa realidade subjacente pela descrição de tantos outros níveis de realidade quanto aqueles pressupostos pelas teorias científicas, não conseguiria efetivamente se distinguir do ponto de vista idealista uma vez que todas as relações subjacentes por ele propostas teriam de ser explicitadas em termos espaciais. Sendo assim, a realidade subjacente à percepção e de natureza distinta dela, só poderia ser alcançada pelo abandono das relações espaciais em que essa percepção se dá, do contrário, nos manteríamos no registro daquela realidade que, mesmo não sendo percebida pelos sentidos, seria passível de ser percebida — registro do idealismo. Confirma-se assim a correspondência, a qual nos referimos anteriormente, entre o universo da percepção e da ciência pela espacialidade no qual o idealismo se move. É nesse sentido que, no limite, o realismo coerente e efetivamente distinto do idealismo, afirmaria um ponto de vista metafísico sobre a realidade, que não poderia ser expresso em termos espaciais, enquanto o idealismo se manteria no nível físico. Encarados desse modo, realismo e idealismo apontam para dois níveis da realidade ou dois sistemas coexistentes e distintos inscritos nela, e não para duas concepções auto-excludentes dessa mesma realidade.

Com efeito, a partir dessas novas hipóteses apresentadas por Bergson, a percepção não pode mais ser entendida como conhecimento da realidade, uma vez que ela não é entendida como uma reprodução, em uma mente, de uma realidade que, por isso mesmo, não estaria nela, mas seria apenas nela re-apresentada. A percepção, na hipótese de Bergson, é parte da realidade, aquela parte que se recorta de um todo maior que ela na medida da ação de um corpo especial em relação a ela. Portanto, não há uma realidade a qual a percepção tenha ou não de se adequar, uma vez que não há uma realidade da qual ela se distinga como cópia ou representação. Há apenas uma realidade que a excede, em todos os níveis, tanto em extensão quanto em profundidade, e que vai se recortando na 
medida da possibilidade de ação de um corpo especial sobre ela. Sendo assim, não faz nenhum sentido falar em apreensão privilegiada da realidade; tanto a ciência quanto a percepção são pontos de vistas diferentes que se distinguirão, essencialmente, por que um se mostrará como um ponto de vista que se quer neutro, e o outro como o ponto de vista construído a partir de um centro, ou, se quisermos, de uma consciência, que, de direito, está implicada desde o momento em que foi detectada uma indeterminação no universo das imagens.

Mas como, de fato, se dá essa implicação ou, nos termos de Bergson, essa dedução da percepção consciente a partir da indeterminação detectada no universo das imagens?

\section{"dedução" da consciência}

Antes de apresentar em que termos Bergson espera poder justificar essa dedução é preciso apresentar rapidamente suas ressalvas. Em primeiro lugar lembremos que até aqui se tem em mente definir aquela percepção ideal que só seria possível para uma consciência colocada no presente e, portanto, abstraída daquela atividade da memória que implica a conservação de lembranças individuais que se impregnam na percepção real e que se tornam tão indiscerníveis dela a ponto de levar muitos a concebê-la como uma visão interior e subjetiva. ${ }^{71}$ Como também é preciso abstrair do fato de que toda percepção, por mais breve que seja, tem uma certa duração e, portanto, um trabalho implícito da memória inerente à essa duração, que contrai os instantes da duração própria

\footnotetext{
${ }^{71}$ Bergson, H. 1999, p. 30.
} 
à matéria prolongando-os uns nos outros na duração que lhe é própria. Abstrações que se justificam quando se quer mostrar justamente que a percepção pura (ou ideal) é a base de toda percepção concreta (ou real), e é o que lhe dá objetividade

Feitas as ressalvas acima, seria possível "deduzir" a consciência dos elementos então considerados por Bergson? Ou seja, dado um campo de imagens; detectada uma indeterminação nesse campo de imagens a partir de uma imagem que se destaca das demais por constituir-se como centro de ação; observado que à complexidade dessa imagem especial correspondem ações cada vez menos necessárias, índice daquilo que Bergson já chama de "percepção, ou seja, de uma relação variável entre o ser vivo e as influências mais ou menos distantes dos objetos que lhe dizem respeito"; ${ }^{72}$ segue-se a percepção consciente na medida mesma dessa indeterminação e da complexidade da imagem pela qual tal indeterminação se insere no campo de imagens?

Com efeito, para Bergson, uma vez que a matéria foi identificada à imagem, ou seja, justamente a uma realidade passível de ser representada, a consciência está posta. "Deduzir a consciência seria uma tarefa bastante difícil, mas, desnecessária, uma vez que ao pôr o mundo material nos damos um conjunto de imagens.,"73

Sendo assim, parece que, antes de qualquer coisa é novamente a evidência do ponto de partida de Bergson, no contexto de sua análise da percepção, ou seja, o campo de imagens no qual a matéria é identificada à imagem, que é chamada para explicar o "surgimento" da consciência.

Sendo assim, é compreensível que, logo após ter afirmado que a consciência está dada, dado o campo de imagens, Bergson volte ao tema da fundamentação de tal identidade,

\footnotetext{
${ }^{72}$ Bergson, H. 1999, p. 29.

${ }^{73}$ Bergson, H. 1999, p. 31.
} 
nos perguntando se seria possível conceber a matéria de uma outra forma. Para Bergson, "nenhuma teoria da matéria escapa a essa necessidade [ao pôr o mundo material pôr um conjunto de imagens]. Reduza a matéria a átomos em movimento: esses átomos, mesmo desprovidos de qualidades físicas, só se determinam em relação a uma visão e a um contato possível, aquela sem iluminação e este sem materialidade. Condense o átomo em centros de força, dissolva-os em turbilhões em evolução num fluido contínuo; esse fluido, esses movimentos, esses centros só se determinam em relação a um tato impotente, a um impulso ineficaz, a uma luz descolorida; ainda imagens."74

Somos levados, então, de volta àquelas considerações explicitadas por Bergson em “O Cérebro e o pensamento", e às quais nos referimos acima, acerca da impossibilidade de falar o que quer que seja sobre a matéria sem nos remetermos a imagens — ou seja, a uma percepção virtual — e, paralelamente, à impossibilidade de não nos remetermos a algo que vai além da matéria, e, na concepção de Bergson, de não nos remetermos a algo que indica aquilo que costumamos chamar de espírito, quando queremos fazer da matéria algo mais do que imagens.

Por outro lado, nenhuma teoria da percepção pode deixar de, ao colocar as imagens atualmente percebidas, ao menos supor a possibilidade da matéria, ou seja, da percepção virtual (e é o que efetivamente se faria quando, ao partir da suposta realidade do todo, esta é reduzida à realidade do corpo próprio e, posteriormente, b cérebro, de onde, então, se retiraria novamente o todo subtraído por meio de uma "varinha de condão"75). Assim, tanto a matéria, entendida como percepção virtual, remete a uma percepção atual, como a percepção atual remete a uma percepção virtual, à matéria. E tal tipo de remissão, natural, para Bergson, só poderia ser quebrada por um passe de mágica.

\footnotetext{
${ }^{74}$ Bergson, H. 1999, p. 31-32.

${ }^{75}$ Cf. Bergson, H. 1999, p. 36-37.
} 
Deve-se tomar cuidado, no entanto, para não confundir esta identificação da matéria à imagem e, conseqüentemente, à afirmação de que ela não se distingue, por natureza, daquilo que percebemos — uma vez que percebemos imagens e afirmamos que a matéria é imagem - com um tipo de subjetivismo. Em primeiro lugar, porque tal identificação não implica a redução da matéria a essa percepção e, em segundo lugar, porque a hipótese contrária implica a própria negação da matéria, justamente por não ser possível caracterizar a matéria de outra forma, a não ser por imagens, sem reduzi-la àquela realidade que, num contexto dualista, costumamos justamente distinguir da matéria, a saber, uma realidade que não pode ser apreendida no modo da extensão, e que possui virtualidades e poderes capazes de gerar sempre o novo.

Além disso, para Bergson, é bastante evidente a legitimidade do ponto de vista por ele assumido, e que ele reputa ao senso comum, uma vez que as críticas engendradas pelos filósofos a essa posição se fundariam nas próprias hipóteses por eles levantadas para solucionar problemas que Bergson acredita poder resolver de outro modo, e sem abrir mão dessa visão considerada ingênua do mundo. Pois, partir de uma realidade caracterizada como um conjunto de imagens, significa considerar a própria realidade com um grau zero de teoria e, para Bergson, fazendo isto, não haveria porque colocar essa realidade sob suspeição e, portanto, colocar tal realidade sob a necessidade de ter sua instância ontológica comprovada. Tal necessidade só ocorreria, de fato, se já interpretássemos essa realidade como dependente da consciência que a percebe, e tivéssemos então de provar se sua existência se resume a essa dependência — sendo ela, então, no máximo, signo da própria existência dessa consciência —, ou se, ao contrário, ela seria signo de uma outra realidade que não a dessa consciência, justamente da realidade de uma matéria então depauperada de seus atributos. Nos dois casos, portanto, 
a realidade da qual se parte já estaria interpretada como aquilo que se convencionou chamar "estados da mente", "dados da consciência", "impressões causadas pela matéria", de qualquer forma, como uma representação sem representado, ou como uma representação cuja natureza se distinguisse daquilo que ela representa, uma realidade, portanto, mais ligada à realidade da consciência do que da matéria, num universo no qual, se há matéria, há uma oposição original, e da qual se parte, entre ela e a consciência.

Para Bergson, com efeito, esta postulação da consciência como substrato de representações, em seu sentido mais forte, e que então abriria espaço para a postulação de um universo material que justamente não seria dado na forma de imagens, teria sido um remédio amargo demais para amortecer nosso desconforto diante das constantes mudanças presenciadas, nesse caso, no universo da matéria.

Nesse sentido podemos entender a crítica feita por ele, no Prefácio à sétima edição de Matéria e Memória, tanto a Berkeley — que, tendo compreendido a impossibilidade de caracterizar a matéria por algo que não fossem imagens, teria, no entanto, reduzido essa matéria às imagens efetivamente percebidas — quanto a Descartes, que, para não reduzir a matéria a esse universo de imagens efetivamente percebidas, a teria descaracterizado enquanto imagem:

\footnotetext{
Um grande progresso foi realizado na filosofia no dia em que Berkeley estabeleceu, contra os "mechanical philosophers", que as qualidades secundárias da matéria tinham, ao menos, tanta realidade quanto as qualidades primárias. Seu erro foi acreditar que para tanto era preciso transportar a matéria para o interior do espírito e fazer dela uma pura idéia. Sem dúvida, Descartes colocou a matéria muito longe de nós ao confundi-la com a extensão geométrica. ${ }^{76}$
}

Sendo assim, reafirmado o campo de imagens, é fundada nesse campo que se dá a identidade entre a matéria e a representação e, portanto, que a representação se põe; mas

\footnotetext{
${ }^{76}$ Bergson, H. 1999, p. 3.
} 
é também no interior desse campo que se explica a distinção entre ambas e, nesse sentido, que se explica a representação que efetivamente experienciamos. E experiência que se explica no interior do campo das imagens porque é o resultado de uma redução nesse campo, e não de nada que a ele se acrescentaria. Pois, se ao partimos desse universo da matéria considerado como um campo de imagens e, nesse sentido, como presença passível de ser representada, tanto a matéria (essa presença) quanto a percepção virtual dessa matéria (representação de direito) estão dadas, nada haveria a acrescentar para explicar a percepção atual da matéria (representação de fato), que, ao contrário, poderia ser explicada por uma subtração. Subtração equivalente, portanto, à percepção apenas de partes da presença, à percepção de objetos, aqueles mesmos constitutivos do campo de objetos que se forma ao redor do corpo próprio a partir de sua ação; ação que, justamente, implica discernimento, ou seja, a não consideração do todo, mas de partes.

\footnotetext{
Isso significa que há para as imagens uma simples diferença de grau, não de natureza, entre ser e ser conscientemente percebidas. A realidade da matéria consiste na totalidade de seus elementos e de suas ações de todo tipo. Nossa representação da matéria é a medida de nossa ação possível sobre os corpos; ela resulta da eliminação daquilo que não diz respeito às nossas necessidades e às nossas funções. (...) A consciência - no caso específico da percepção exterior — consiste precisamente nessa escolha. Mas há, nessa pobreza necessária de nossa percepção consciente algo de positivo e que já anuncia o espírito: é, no sentido etimológico do termo, o discernimento. ${ }^{77}$
}

Sendo assim, recapitulemos. Bergson, ao caracterizar a realidade como um conjunto de imagens e, portanto, como uma presença, algo que, por natureza se presta à apreensão, ainda que não seja apreendida de fato, ou seja, algo que não tem sua existência determinada por essa apreensão, propõe que a consciência já está dada, uma vez que a consciência seria justamente essa possibilidade de apreensão. E, nesse sentido, "consciência" não implica uma ruptura no seio da realidade, uma vez que ela é constitutiva da própria realidade.

\footnotetext{
${ }^{77}$ Bergson, H. 1999, p. 35.
} 
Ocorre, no entanto que tal Consciência, entendida como co-extensiva à matéria (e que será tematizada em Evolução Criadora como "energia criadora", fundamento para tudo o mais) se distingue de nossa experiência consciente da realidade, ou daquilo que podemos chamar de consciência individual. E se distingue, mais uma vez, não como ruptura, mas como redução, justamente aquela redução que intuímos quando, antes de teorizarmos e, portanto, mantendo-nos naquela experiência que os filósofos consideram ingênua, acreditamos que percebemos o mundo em sua realidade, ainda que não o percebamos em toda a sua realidade. Assim, o problema que se apresenta não é mais o de explicar como as imagens que representariam o mundo surgem de uma consciência, uma vez que as imagens são dadas juntamente com o mundo (que, nesse sentido pode ser identificado a uma Consciência). O problema, então, seria o de saber como essa Consciência se torna uma consciência, se adéqua ao "tamanho" da nossa consciência, necessariamente, reduzida, do mundo.

Mas essa redução, ou, se quisermos, a distância que separa o todo da parte, é o que justamente Bergson acredita poder explicar a partir da atuação do corpo próprio, pela qual se explicaria tanto o caráter objetivo dessa representação, uma vez que ela é o resultado de um recorte fundado na realidade, quanto seu caráter subjetivo, uma vez que esse recorte implica uma afecção a partir da qual tal parte do todo é apropriada, e uma memória pela qual ela é contraída e recoberta. ${ }^{78}$

\footnotetext{
${ }^{78}$ Bergson apresentará várias analogias para tornar mais palpável, sua concepção de percepção consciente.

Ora ela é apresentada como a interrupção do fluxo contínuo de algumas daquelas ações que se estabelecem entre as imagens em geral, interrupção que faria com que a energia então represada voltasse por reflexão total na direção daquela imagem de onde partira, iluminando os contornos de sua superfície (Cf. Bergson, H. 1999, p. 39); ora, aproveitando-se da analogia clássica que apresenta a percepção como uma visão fotográfica das coisas, e interpretando-a a seu favor, afirma que, se há fotografia, ou seja, imagem, ela já foi tirada no interior mesmo das coisas, e para todos os pontos do espaço. Fotografia, no entanto, translúcida, e que necessita de uma tela negra que colocasse em destaque a imagem nela existente (Cf. Bergson, H. 1999, p. 36).
}

Sem enumerar todas as analogias às quais ele se refere, gostaríamos apenas de destacar o que é comum a todas elas, a saber: que a percepção não é reprodução nem produção de imagens, e que, ao contrário, é recorte feito em um 
Assim, só há consciência, no sentido em que a experienciamos, aquela que, ao se colocar, coloca o outro, e, portanto, aquela que é sinal de uma distância instaurada no interior do campo de imagens, na individualidade e contingencialidade determinadas a partir do corpo próprio. No entanto, tal distância não significa uma ruptura no seio do ser campo transcendental de imagens - que colocaria, diante, uma da outra, duas naturezas distintas, e isto na medida mesma em que é possibilitada por um sentido de ser que carrega, colado a ele, a representatividade.

Se, portanto, segundo a interpretação de Bergson, não se trata mais de ter de dar objetividade às imagens, ou à representação do mundo, uma vez que a representação do mundo e o mundo não diferem em natureza, trata-se, agora, de explicar o caráter subjetivo de tal representação, ou, o que, ao mesmo tempo, explicará como tal representação ganha distância em relação à presença e, nesse sentido, se torna representação em sentido estrito, consciência individual, ou, se quisermos, alteridade.

percepção e afecção

Bergson acredita - e justamente o vem denunciando desde o início de sua argumentação — que nossa observação do mundo está viciada por pressupostos que já se tornaram imperceptíveis para nós. Devemos nos livrar de qualquer conceito prévio ao olhar o

universo de imagens já dado. Portanto, que a matéria e sua percepção não são de naturezas distintas, uma, extensão no espaço, outra, realidade não-extensa em uma consciência, mas a mesma realidade tomada a partir de um ponto de vista neutro ou a partir daquele ponto de vista definido pela indeterminação inserida no universo das imagens por um ser vivo. Nesse sentido, se ressalta o caráter imanente e objetivo da percepção, que se desenha, a partir de uma realidade dada como campo de imagem, ou seja, como realidade virtualmente percebível, por uma ação real que introduz uma indeterminação relativa às necessidades de um princípio que então se introduz nesse campo de imagens, e que Bergson identifica àquilo que chamamos de vida. 
mundo, mesmo aqueles que nos parecem mais fundamentados, como os conceitos correlatos de sujeito e objeto da percepção, realidades distintas de antemão que se colocariam uma diante da outra e de alguma forma entrariam em contato. Devemos tomar como modelo a experiência da criança que, imersa no mundo, pouco a pouco vai discernindo, nesse universo de imagens, aquelas que se mantêm constantes e que se tornam o centro desse seu universo, a partir das quais ela se constituirá como indivíduo. ${ }^{79}$ Para Bergson, o caminho mais propício para a compreensão de como percebemos as coisas que nos cercam se dá, portanto, em sentido contrário àquele efetuado pelos filósofos, uma vez que ele deve se dar no sentido do mais ao menos abrangente, no sentido da observação da delimitação, da diminuição, das contrações efetuadas em um todo previamente dado, uma vez que, partindo do todo, é plenamente possível nos dar suas partes. Assim, seria plenamente possível explicar uma percepção pela qual "eu me coloco desde o início em um mundo material em geral, para progressivamente limitar esse centro de ação que se chamará meu corpo e distingui-lo, então, de todos os outros." Nesse sentido, ainda, a impossibilidade, na qual nos colocamos, de manter um contato direto com a realidade do mundo que nos cerca fundamenta-se particularmente na recusa de partir do mundo, e de, ao enxergar o mundo como um dado, fundamentar nele sua percepção, considerando-a, então, objetivamente. Ao contrário, procuramos reconstruí-la a partir da subjetividade, percorrendo, em sentido contrário, do centro à periferia, um caminho que já havíamos realizado intuitivamente quando estávamos livres de qualquer teoria. Partindo "do meu eu consciente ao meu corpo e do meu corpo aos outros corpos", teremos de partir do menos para o mais, de reconstruir, não só o universo inteiro das nossas representações como os das demais consciências, trabalho tão árduo que tem se

\footnotetext{
79 “Os psicólogos que estudaram a infância sabem bem que nossa representação se inicia de modo impessoal. É apenas paulatinamente, devido a várias induções, que ela adota nosso corpo por centro e se torna nossa representação" (grifo do autor). Bergson, 1999, p. 45.
} 
mostrado impraticável. E justamente com base na crítica à hipótese teórica com a qual a psicofísica contava para poder explicar tal reconstrução, a saber, a hipótese da identidade de natureza entre essas afecções e a representação, é que Bergson vai construir sua teoria da afecção, teoria que, por fim, implicará a primeira correção da então proposta teoria da percepção pura.

Hipótese presente, por exemplo, na concepção de sensação de H. Taine que, em seu De L’intelligence, 1870, defende que “os choques entre as células nervosas se tornariam sensações em nós e, posteriormente, imagens, as quais, por sua vez, se transformariam em percepções por sua projeção sobre o objeto, tal como uma alucinação verdadeira".

Nesse sentido, as sensações precederiam a percepção dos objetos materiais e esta, de mesma natureza que aquela, seria considerada como a exteriorização de estados internos e inextensos que, de alguma forma, ganhariam extensão.

A essa concepção de sensação e de percepção - que explica a percepção do sentido centro-periferia — Bergson propõe uma nova hipótese que configurará sua "teoria da afecção" e que, em sentido oposto à hipótese criticada se propõe a mostrar como "a afecção deve, em uma determinado momento, surgir da imagem" — no sentido periferiacentro.

Comecemos então pela crítica ao pressuposto teórico da identidade de natureza entre afecção (ou sensação) e representação que, segundo Bergson, baseia-se no suposto fato de que "passamos insensivelmente do estado representativo, que ocupa lugar no espaço, ao estado afetivo que parece inextenso" e do qual se seguiria o fato básico da percepção sustentado pelas teorias da representação criticadas até aqui, ou seja, "a inextensão 
natural e necessária de toda sensação, sendo a extensão adicionada à sensação e o processo da percepção uma exteriorização de estados internos." 80

O caminho percorrido pelos teóricos criticados seria, segundo Bergson, o seguinte:

\begin{abstract}
O psicólogo parte, com efeito, de seu corpo, e como as impressões recebidas na periferia desse corpo parecem ser suficientes para a reconstituição de todo o universo material, ele de início reduz o universo a seu corpo. Mas essa primeira posição não é sustentável: seu corpo não tem nem pode ter nem mais nem menos realidade que todos os outros corpos. Sendo assim, é preciso ir além, seguir até o fim a aplicação do princípio e, depois de ter reduzido o universo à superfície do corpo vivo, contrair esse mesmo corpo em um centro que, finalmente, erá suposto inextenso. Desse centro, então, partirão sensações inextensas que, por assim dizer, se avolumarão, aumentarão em extensão e acabarão por dar, primeiramente, nosso corpo extenso e, depois, todos os objetos materiais. Mas essa estranha suposição não seria possível justamente se não houvesse entre as imagens e as idéias, estas inextensas e aquelas extensas, uma série de estados intermediários, confusamente localizados, que são os estados afetivos. Nosso entendimento, cedendo a sua ilusão habitual, apresenta o dilema de que uma coisa deve ser ou não extensa; e como o estado afetivo participa vagamente da extensão, e como é imperfeitamente localizado, conclui-se que esse estado é absolutamente inextenso; a história da percepção vai se tornar a dos est ados internos e inextensos que se estendem e se projetam para fora. ${ }^{81}$
\end{abstract}

Em outras palavras, parte-se da suposição de que a intensificação da percepção de um objeto exterior ou, se quisermos, da ação de sua causa sobre nosso corpo, se transforma em um sentimento, geralmente de dor. Assim, a intensificação da percepção da agulha se transformaria no sentimento da picada, ou a intensificação da percepção do calor do fogo se transformaria na dor da queimadura e assim por diante. Inversamente, a diminuição da dor levaria à percepção de sua causa, o sentimento se exteriorizaria em percepção. Essa transformação do sentimento, ou afecção, em percepção e vice-versa (de acordo com a intensidade da ação de uma causa exterior sobre o nosso corpo) justificaria a consideração de que tanto a afecção quanto a percepção são de mesma natureza, já que uma, a todo momento, estaria se transformando na outra apenas por diminuição ou aumento de intensidade; e, como parece absurdo não reputar a afecção ou sentimento a um sujeito (a fecção desaparece se o sujeito desaparece) reputa-se a ele também a percepção (esta também desapareceria se o sujeito desaparecesse). Explica-se, assim, como a percepção pode ser considerada a exteriorização de um estado do sujeito; bastando para tanto que tal estado perca intensidade e que seja projetado no espaço. Para

\footnotetext{
${ }^{80}$ Bergson, H.1999, p. 52.

${ }^{81}$ Bergson, H. 1999, p. 52.
} 
Bergson, tanto idealistas quanto realistas concordam com essa descrição dos fatos, discordando apenas quanto a se esses estados mentais, que ganham "extensão" e aparência de exterioridade, corresponderiam ou não a uma realidade distinta da do sujeito e que os teria causado. Sendo assim, tanto realistas quanto idealistas concordariam em que a percepção é o resultado de um processo de exteriorização de estados internos do sujeito, portanto, totalmente restrita ao âmbito subjetivo, ao menos até que se possa provar a realidade objetiva da causa desses estados que, em última instância, os unificaria em objetos; prova que obviamente não poderá ser obtida por meio dessa mesma percepção, i. e., por meios empíricos (o que, de resto, interdita ao empirismo qualquer afirmação sobre a realidade das coisas). Perfazendo, portanto, o caminho inverso daquele proposto por Bergson, realistas e idealistas concluem que a "representação do universo material (...) sai de nós, em vez de sermos nós quem nos destacamos dela”.

Para Bergson está claro que tal interpretação pode ser criticada, em primeiro lugar, porque não explica nem a natureza da dor, nem a da percepção, ou seja, nem por que em um determinado momento o enfraquecimento da afecção lhe confere um caráter de extensão e uma aparência de independência nem como, por um aumento de intensidade, a percepção se torna afecção ou, mais comumente, dor. Antes de por em questão os fatos, ou seja, que "o aumento gradual da excitação acaba transformando a percepção em dor; e que essa transformação começa a ocorrer a partir de um momento em especial”, Bergson observa que a hipótese da identidade de natureza entre a sensação e a percepção não responde às questões levantadas por esses mesmos fatos. Tal hipótese não explica, portanto, "nem porque, em um momento determinado, uma diminuição de intensidade no fenômeno lhe confere direito à extensão e uma aparente independência, nem como um aumento da 
intensidade cria, em um momento preferencialmente a outro, essa nova propriedade, fonte de ação positiva, que chamamos de dor.",82

Por outro lado, o quadro teórico proposto por Bergson transforma as soluções porque transforma os problemas colocados. Nele, não há mais, propriamente falando, necessidade de explicar como um estado inextenso ganha extensão ou como ganha uma aparência de independência, dado que não há estados interiores a uma mente e, portanto inextensos, que seriam projetados para o exterior na forma de imagens sensíveis, como também não há necessidade de explicar uma aparência de independência desses estados uma vez que essa independência é real. E, principalmente, não há aqui, como já notamos, a necessidade de explicar como essas imagens são criadas, uma vez que elas são dadas desde o início. O que se deve explicar é como, dessas imagens, surgem dois fenômenos diferentes que denominamos percepção e afecção, fenômenos que estão relacionados a delimitações nesse campo de imagens e que, se introduzem algo de novo nesse universo, essa novidade será justamente o signo de uma realidade distinta dele, e não o signo de uma realidade a ele inerente e escondida. Sendo assim, se quisermos entender a percepção e esse tipo especial de percepção que chamamos de afecção, devemos percorrer, mais uma vez, o percurso que vai do universo das imagens na direção dessas imagens particulares que chamamos de corpo próprio, a partir da qual podemos conceber que esse universo seja recortado e, como veremos adiante, contraído e recoberto, mas não recriado.

Partamos então do universo das imagens, que se delimitará como percepção para centros de ação que se estabelecem a partir de imagens especiais que chamamos de corpo próprio. Sendo assim, essa delimitação se dará na medida da possibilidade e da complexidade das ações realizadas a partir desse centro, ou, se preferirmos, desse corpo

\footnotetext{
${ }^{82}$ Bergson, H. 199, p. 55.
} 
próprio. Quanto maiores forem as possibilidades dessas ações, maior será o campo de imagens abarcadas a partir desse centro e, portanto, maior a distância entre o corpo, a partir do qual se efetivará ou não a ação, e os objetos percebidos. No entanto, essa imagem a partir da qual se delimita o campo de percepção (pela ação apenas possível que partiria dela na direção das demais imagens,) não é ela mesma pontual, mas possui uma certa espessura, ou seja, é ela própria um conjunto de imagens que têm entre si estabelecidas também relações de ação e reação. Ocorre, no entanto, que nesse caso não se trata mais de ações apenas possíveis, mas de ações reais, uma vez que a distância entre o centro de onde emana a ação e seu objeto é nula. Ação real que, retornando ao seu ponto de origem, não se projeta mais para fora de nosso corpo, mas para um interior que tem como limite externo a superfície desse corpo ou, se quisermos, nossa epiderme. ${ }^{83}$

Em resumo, Bergson nos diz:

Considere esse sistema de imagens que se chama mundo material. Meu corpo é uma entre elas. Ao redor dessa imagem se dispõe a representação, quer dizer, sua influência eventual sobre as outras. Nela se produz a afecção, ou seja, seu esforço atual sobre ela mesma. Tal é, no fundo, a diferença que cada um de nós estabelece naturalmente, espontaneamente, entre uma imagem e uma sensação. Quando dizemos que uma imagem existe fora de nós, entendemos por isso que ela é exterior ao msso corpo. Quando falamos da sensação como um estado interior, queremos dizer que ela surge no nosso corpo. E é por isso que dizemos que a totalidade das imagens percebidas subsiste mesmo se nosso corpo desaparecer, enquanto não podemos suprimir nosso corpo sem fazer nossas sensações desaparecerem. ${ }^{84}$

Para além de todos os meandros da hipótese de Bergson, o que nos interessa sobretudo demarcar aqui é o fato de que tanto a percepção quanto a afecção são explicadas

\footnotetext{
83 “Tudo se passará então como se, por um verdadeiro retorno das ações reais e virtuais aos seus pontos de aplicação ou de origem, as imagens exteriores fossem refletidas por nosso corpo no espaço que o rodeia, e as ações reais presas por ele no interior de sua substância."

${ }^{84}$ Bergson, H. 1999, p. 58-59.
} 
por ele em termos das ações, forças e imagens que eram desde o início dados do universo do qual ele partiu. O interior e o exterior ao qual ele se refere, como não poderia deixar de ser, dizem respeito à extensão inerente às imagens. Assim, a percepção é algo que diz respeito ao universo exterior ao nosso corpo, afecção é algo que ocorre no interior de nosso corpo, mas, ainda aqui, tudo ocorre em relação ao nosso corpo, nada tendo sido dito em relação a uma interioridade relativa a estados mentais, e uma exterioridade relativa à matéria. Sendo assim, "da mesma forma em que os objetos são percebidos por mim onde eles estão, neles e não em mim, meus estados afetivos são experimentados lá onde eles se produzem, ou seja, em um determinado ponto do meu corpo.(...) Tal é, no fundo, a diferença que cada um de nós estabelece naturalmente, espontaneamente, entre uma imagem e uma sensação. Quando dizemos que uma imagem existe fora de nós, entendemos por isso que ela é exterior ao nosso corpo. Quando falamos da sensação como um estado interior, queremos dizer que ela surge no nosso corpo." ${ }^{\circledR 5}$ Aqui o que há é sempre a matéria, seus campos de força e de ações e reações. O surgimento de centros de ação que vem de alguma forma alterar um universo onde impera a necessidade para nele introduzir a possibilidade é ainda apenas o prenúncio dessa outra natureza que chamamos de espírito.

Ocorre ainda que, se há distinção entre a percepção e a afecção, porque uma se dá pela demarcação de um campo de ação possível, e a outra por uma ação que se realiza, no entanto, uma não se dá sem a outra. Ou seja, desde que consideremos a espessura do nosso corpo, todas as ações que se dirigem a ele e que dele partem efetuam-se também em relação a essa espessura. Assim, ao mesmo tempo em que consideramos que há um movimento de reflexão daquelas ações dos objetos exteriores em relação ao nosso corpo e um movimento de absorção em relação ao que é interior a ele, também devemos considerar que esse mesmo movimento de absorção modifica o de reflexão. Dado que

\footnotetext{
${ }^{85}$ Bergson, H. 1999, p.
} 
esse corpo tem de ser considerado em sua complexidade ou em suas partes, tem-se de considerar também que as partes postas em movimento pelas ações recebidas do exterior, além de refletirem essa ação e suscitarem a percepção de algo exterior, ao absorverem uma quantidade dessa ação dão origem a um novo tipo de percepção, a percepção dela própria, ou seja, de uma parte do corpo — que é assim isolada por esse movimento — pelo próprio corpo, justamente o que constitui a afecção para Bergson.

Assim, a afecção, por ser a percepção interior a uma imagem, imagem especial a partir da qual outras imagens serão percebidas externamente, se interpõe entre essa imagem especial e as demais, impedindo que ocorra um corte seco no objeto total, acrescentando, ao recortá-lo, aspectos que não lhe pertenciam.

\footnotetext{
Até aqui raciocinamos como se nossa percepção fosse uma parte das imagens destacada sem modificações de sua substância, como se, ao expressar a ação virtual do objeto sobre o nosso corpo ou de nosso corpo sobre o objeto, ela se limitasse a isolar do objeto total o aspecto que não nos interessa. Mas é preciso levar em conta que nosso corpo não é um ponto matemático no espaço, que nossas ações virtuais se complicam e se impregnam de ações reais, ou, em outros termos, que não há percepção sem afecção. A afecção é, portanto, aquilo que adicionamos do interior de nosso corpo à imagem dos corpos exteriores; ela é o que devemos extrair da percepção para reencontrar a pureza da imagem. ${ }^{86}$
}

Sendo assim, anteriormente considerada como a matéria-prima da percepção, a afecção passa a ser um tipo de impureza que a ela se acrescenta, o que, de resto, explica o caráter subjetivo de nossas percepções. Subjetividade que se explica, no entanto, porque, de fato, não temos acesso a uma parte da matéria que seria simplesmente destacada de seu todo, mas a partes destacadas às quais foi acrescentado algo que diz respeito ao nosso corpo. E, nesse sentido, acrescidas de algo pertencente a este corpo, se promove o efetivo destaque dessas partes em relação ao todo, pelo que elas se tornam partes para esse corpo, objeto para uma consciência.

${ }^{86}$ Bergson, H. 1999, p. 59. 
Subjetividade, ainda, que continua se efetivando, no entanto, na extensão e, de forma alguma, em um estado inextenso da mente. A afecção se dá em uma extensão, aquela interior ao nosso corpo, e a percepção real, ainda que necessariamente indissociável da afecção, não é construída por ela.

Para Bergson, da mesma forma que os idealistas e realistas por ele criticados tinham dificuldade em aceitar que a percepção se dava no objeto percebido e acabavam por colocála na mente de quem percebe - encarando-a como o resultado de uma exteriorização, de resto inexplicável, de estados dessa mente — , assim também eles não poderiam aceitar que as afecções se dessem nos nervos sensitivos, ou em determinadas partes físicas do corpo. O que resulta na expulsão inevitável dessa sensação do domínio do extenso, assim como na remissão das sensações ao domínio do inextenso, "nos representaremos então sensações absolutamente inextensas e, de outro lado, um espaço vazio, indiferente às sensações que nele virão se projetar". Mas, novamente, o problema relativo a como o inextenso ganha extensão ${ }^{87}$, ou a como as diferentes extensões sensíveis ganham unidade objetiva, acrescido aqui, especificamente, do problema relativo a como as afecções surgem na mente, ficam sem solução ou apresentam soluções que, segundo Bergson, engendram novos problemas. Com efeito, uma vez que se considere possível "explicar" como se dá a passagem das sensações inextensas para as diferentes extensões sensíveis, será preciso explicar ainda a unidade objetiva dessas sensações. Todos sabemos que se, por um lado, a matéria foi alijada de suas características sensíveis devido à relatividade ou subjetividade que se acreditava inerente a essas características, e transformada em uma 'causa oculta' delas, por outro lado sua realidade subjacente deveria ser a garantia da unidade objetiva dos dois tipos de

\footnotetext{
87 “As sensações em questão são inextensas. Como elas adquirem extensão? Quer vejamos na extensão um campo pronto para receber sensações ou apenas um efeito da simultaneidade das sensações que coexistem na consciência sem se fundir uns nos outros, em um caso como no outro introduziremos com a extensão algo de novo que não podemos explicar, e o processo pelo qual a sensação adquire extensão, a escolha por cada sensação elementar, de um determinado ponto no espaço, permanecerão inexplicados.” Bergson, H. 1999, p. 64.
} 
extensão perceptíveis, a saber, a extensão visual e a extensão tátil, uma vez que estas, entre si, nada tinham em comum. O que só fortalece a necessidade de conceber essa realidade material totalmente descaracterizada sensivelmente e, nesse sentido, como realidade inatingível e com poderes não revelados na percepção. No entanto, ao negar qualquer característica perceptível à matéria, e transformá-la em uma "entidade misteriosa", tampouco poderíamos dizer que sabemos algo sobre o funcionamento ou a razão de ser de um espírito, uma vez que não poderíamos determinar a origem nem a utilidade de seus diferentes estados, as afecções.

A solução apresentada por Bergson, eliminaria essas questões internas à teoria criticada justamente ao estabelecer uma percepção que, ao menos no estado de pureza em que ele procura isolá-la, nos dá a extensão em sua realidade, uma "percepção que, em seu estado puro, fará, portanto, verdadeiramente parte das coisas”. Por outro lado, a sensação também se resolve no domínio dessa extensão e, sendo assim, mostra-se indissociavelmente unida à percepção pela via, agora, do que é extenso: “a sensação, propriamente dita, não surge das profundezas da consciência para se estender, ao se enfraquecer, no espaço, bem ao contrário, coincide com as modificações necessárias que sofre, no meio das imagens que o influenciam, essa imagem particular que cada um de nós chama de seu corpo." ${ }^{88}$

Mas, mais do que isso, a solução apresentada por Bergson eliminaria o próprio problema do conhecimento da matéria, bem como o do espírito, pois pela própria delimitação do que seria a matéria em seu estado puro, seria possível caracterizar como proveniente de outra realidade tudo aquilo que a ela se acrescentasse. E é nesse sentido que a tematização da memória entrará com seu papel primordial na determinação da instância espiritual, uma vez que a conservação das imagens, que de alguma forma orienta a delimitação do campo de possibilidades no qual se inscreve a percepção, será o primeiro

\footnotetext{
${ }^{88}$ Bergson, H. 1999, p. 67.
} 
sinal dessa instância que extrapola o estritamente material e com ela interage. ${ }^{89}$ Atividade de conservação de imagens que, considerada então em sua pureza, deverá ser comprovada como aquilo que seria o domínio por excelência do espiritual.

percepção e lembrança

Mas a identificação da memória pura ao espírito ultrapassa em muito nosso atual objeto de análise. Continuemos seguindo Bergson na apresentação de sua teoria da percepção que se dá concomitantemente à crítica às posições idealistas e realistas e, portanto, na tematização da interação entre a memória e a matéria dada nessa percepção. E vejamos então como Bergson inicia a exploração da atuação da memória na percepção, a saber, quando ocorre a mistura e a freqüente substituição das imagens conservadas na memória sobre as imagens dadas na percepção atual, "pois, uma vez que elas só se conservam para se tornarem úteis, a todo instante elas completam a experiência presente ao enriquecê-la com a experiência adquirida; e como esta é cada vez maior, acaba por recobrir e por submergir a outra", 90

No entanto, ao complexizar sua teoria da percepção com a introdução da atuação da memória, Bergson detecta também uma outra fonte do erro que teria levado à subjetivação de nossa percepção. Com efeito se, para ele, a memória é a ocasião por excelência de explicitação de uma instância independente da matéria, no entanto, o que comumente

\footnotetext{
89 “Que nossa consciência desempenha sobretudo esse papel na percepção exterior, pode ser deduzido a priori da própria definição de corpo vivo. Pois, se esses corpos tem por objetivo receber excitações para elaborá-las em reações imprevistas, a escolha da reação não deve, no entanto, se dar ao acaso. Essa escolha se inspira, sem dúvida, em experiências passadas, e a reação não se faz sem um apelo a lembranças que situações análogas deixaram atrás de si. A indeterminação das ações a serem realizadas exige, portanto, para não se confundir com o puro capricho, a conservação de imagens percebidas." Idem, ibidem.

90 Bergson, H. 1999, p. 68.
} 
ocorre, devido à constante associação de imagens provenientes da memória às imagens dadas na percepção é o surgimento de mais uma ocasião para confundir aquilo que provém/reside do sujeito, suas lembranças, e aquilo que provém/reside na matéria, as imagens, o que redunda, frequentemente, em mais uma ocasião para 'espiritualizar' essa matéria .

Ainda que Bergson admita que o volume de imagens provenientes da memória e que se sobrepõem à imagem percebida é tão superior que, na prática, "perceber se torna apenas uma ocasião para lembrar", 91 essa ocasião, ou esse fundo de objetividade exterior permanece e é essencial para que qualquer imagem venha a ele se somar e construir a percepção real, fato que, no entanto, não é levado em consideração por aqueles que não procedem à distinção metodológica proposta por Bergson entre a percepção pura e a atividade da memória constantemente associada a ela. E isso ocorre porque, uma vez que as lembranças se mantêm em um processo de acumulação e sobreposição contínuo em relação ao dado objetivo da percepção, é fácil confundir lembrança e percepção e reputar a esta o caráter subjetivo daquela.

Descobrimos aqui o erro daqueles que vêem na percepção uma projeção exterior de sensações inextensas tiradas de nós mesmos e posteriormente estendidas no espaço. É fácil para eles mostrar que nossa percepção completa está cheia de imagens que nos pertencem pessoalmente, de imagens exteriorizadas (ou seja, no fundo, rememoradas); esquecem-se apenas que um fundo pessoal permanece, no qual a percepção coincide com o objeto percebido, e que esse fundo é a própria exterioridade. $^{92}$

\footnotetext{
91 "É preciso levar em conta que perceber acaba sendo nada mais que uma ocasião para recordar, de que medimos os graus de realidade pelos graus de utilidade, de que temos todo o interesse enfim em erigir em simples signos do real essas intuições imediatas que coincidem, no fundo, com a própria realidade". Idem, ibidem.

${ }^{92}$ Idem, ibidem.
} 
Sendo assim, não distinguir em nossa percepção aquele fundo objetivo das lembranças que sobre ele se acumulam, portanto, não proceder a distinção de natureza existente entre lembranças e percepção, levaria à consideração desses estados mistos como estados simples que se transformariam um no outro apenas por meio de um acréscimo ou diminuição de intensidade.

De um lado, essa confusão entre lembrança e percepção tem como efeito imediato uma confusão restrita à psicologia, mais explicitamente, às teorias sobre a memória, "pois, ao fazer da lembrança uma percepção mais fraca, desconsideramos a diferença essencial que separa o presente do passado, renunciamos a compreender os fenômenos do reconhecimento e, de um modo geral, o mecanismo do inconsciente". 93

De outro lado, no entanto, tal indistinção tem como efeito muito mais nocivo o de impossibilitar tanto o conhecimento da matéria quanto do espírito. O erro principal, portanto, ao qual somos levados ao não distinguir lembrança e percepção é o de, assim fazendo, não poder distinguir o subjetivo do objetivo e, nesse sentido, tanto postular esta distinção quanto ter acesso a cada uma das realidades que a sustentariam. Se não, vejamos.

Se as lembranças são percepções mais fracas, inversamente, as percepções são lembranças mais fortes e, nesse sentido, assim como as lembranças, nossas percepções terão sua origem em um sujeito e sua natureza identificada a estados desse sujeito. Estamos de volta, agora pela via da identidade de natureza entre lembrança e percepção, ao domínio do estritamente subjetivo, do qual, segundo Bergson, nem o realismo nem o idealismo conseguiram escapar. Tudo isso porque mais uma vez perdemos o contato direto, na percepção, com as coisas percebidas; porque "desconsideramos o ato original e

\footnotetext{
${ }^{93}$ Bergson, H. 1999, p. 70.
} 
fundamental da percepção, aquele ato, constitutivo da percepção pura, pelo qual nos colocamos nas coisas." ${ }^{94}$ Como vemos, para Bergson, todo processo da percepção se esclareceria se, ao invés de colocarmos as coisas em nós - o que fazemos quando consideramos a percepção como uma síntese de estados internos exteriorizados ou, ainda, quando consideramos que o único traço distintivo entre a percepção e a lembrança é sua intensidade - compreendêssemos, enfim, que somos nós quem nos colocamos nas coisas.

Para Bergson, portanto, o principal erro está em compreender o processo da percepção como o da contemplação do mundo exterior que acabaria por se projetar em nossa mente, a partir de processos mais interiores, como em uma tela.

Toda especulação de Bergson visa quebrar essa concepção que constitui quase um hábito epistemológico, se assim podemos dizer. Daí sua dificuldade. A percepção não é contemplação de imagens do mundo, é atuação nesse mundo de imagens, a partir da qual, então, essas imagens se tornam conteúdo de contemplação, ou seja, idéias ou lembranças em uma memória. Mas essas imagens só se transformam em idéias, ou lembranças, quando já são passado e, portanto, quando já não agem. O presente ativo é, nesse sentido, a marca distintiva entre a percepção e a lembrança, esta que, por pertencer ao passado e não poder mais agir, precisa, para tanto, ser atualizada pelo presente. "A atualidade de nossa percepção consiste, portanto, em sua atividade, no movimento que a prolonga, e não em sua maior intensidade: o passado é apenas idéia, o presente é 'idéo-motor'.”

Ocorre, no entanto, que essa ação que se dá no presente não é instantânea, ao contrário, ela possui uma duração própria que se impõe à matéria. O que leva a mais um nível de uma complexização crescente assim resumida por Bergson:

\footnotetext{
${ }^{94}$ Bergson, H. 1999, p. 70.
} 
Com efeito, nossa percepção pura, por mais rápida que a possamos supor, ocupa uma certa duração, de modo que nossas percepções sucessivas nunca são momentos reais das coisas (...) mas momentos de nossa consciência. O papel teórico da consciência na percepç̃o exterior, nós dizíamos, seria o de unir entre si, pelo fio contínuo da memória, visões instantâneas do real. Mas, de fato, o instantâneo não existe para nós. Naquilo que chamamos por esse nome está implícito um trabalho da memória e, consequentemente, de nossa consciência que prolonga uns nos outros os numerosos momentos de um tempo indefinidamente divisível, de modo a que sejam apreendidos em uma intuição relativamente simples. ${ }^{95}$

E aqui, me parece, o golpe de mestre dado por Bergson sobre aqueles que defendem uma concepção realista da matéria ou, se quisermos, o ponto onde reside a superioridade de sua hipótese. Pois, se, na concepção realista, a distinção entre extenso e inextenso é o que estrutura a matéria por oposição ao espírito, é também o que faz com que a matéria e a percepção da matéria não apresentem ponto de contato possível, uma vez que uma é constituída por movimentos homogêneos no espaço, enquanto a outra constitui-se como sensações heterogêneas e inextensas na mente. Na hipótese de Bergson, no entanto, essa heterogeneidade e homogeneidade, assim como a relação entre o extenso e o inextenso serão reeditadas em outros termos, o que, ao mesmo tempo, dará conta da distinção e do contato entre a matéria e sua percepção e, como veremos mais à frente, entre a matéria e o espírito. Mantendo-nos, por ora, no nível da distinção e do contato entre a matéria e sua percepção, não é a própria hipótese do recobrimento e da contração efetuados pela memória na matéria, e que dão conta da "heterogeneidade qualitativa de nossas percepções sucessivas", o que nos leva a concluir que, retirada a memória encontraríamos ... uma multiplicidade de estímulos homogêneos?! "A matéria, então, tornada cada vez mais homogênea, na medida em que nossas sensações extensivas se repartissem sobre um número cada vez maior de momentos, tenderia indefinidamente na direção do sistema homogêneo do qual fala o realismo." ${ }^{96}$ Ocorre que, para surpresa do realista, ainda que a matéria pura coincidisse com esses estímulos homogêneos múltiplos

\footnotetext{
${ }^{95}$ Bergson, H. 1999, p. 72

${ }^{96}$ Bergson, H. 1999, p. 73
} 
e sucessivos e sua percepção concreta com qualidades heterogêneas e indivisas, o contato entre ambos estaria garantido, uma vez que tanto a percepção - em seu estado de pureza, considerada sem as alterações nela efetuadas pela memória (e, portanto, enquanto ações) —, quanto a matéria, se dariam na extensão. "Não será preciso, portanto, colocar de um lado o espaço com movimentos impercebidos, de outro, a consciência com sensações inextensas. É, ao contrário, em uma percepção extensa que sujeito e objeto se unirão, consistindo o aspecto subjetivo da percepção na contração que a memória opera, a realidade objetiva da matéria confundindo-se com os estímulos múltiplos e sucessivos nos quais essa percepção se decompõe interiormente."97

Se, portanto, a alteração mais fundamental operada pela memória na percepção da matéria é uma contração temporal, portanto, o que distingue a matéria da percepção da matéria é um descompasso de tempo. Há então a substituição do critério espacial de distinção entre ambas, quando a uma era reputada um caráter extenso e à outra um caráter inextenso, e Bergson pode adiantar o que espera poder afirmar conclusivamente na última parte do texto, a saber, que "as questões relativas ao sujeito e ao objeto, a sua distinção e união, deveriam se colocar mais em função do tempo do que em função do espaço”.

Assim, da mesma forma que suas considerações sobre a percepção pura lhe deram indicações sobre a natureza da matéria que marcaram seu posicionamento em relação ao realismo e ao idealismo, é possível retirar, de suas considerações sobre a memória pura, indicações sobre a natureza do espírito que marquem seu posicionamento em relação ao materialismo e ao espiritualismo.

${ }^{97}$ Idem, ibidem. 
Em outras palavras, a partir da hipótese defendida por Bergson e, segundo a qual, pela percepção pura mantemos contato direto com parte da matéria, e que, portanto, não há uma diferença de natureza entre a matéria e sua percepção, mas uma diferença análoga àquela existente entre a parte e o todo, podemos afirmar que a matéria não possui qualquer virtualidade escondida, ou não pode exercer nenhum poder diferente daquele dado na percepção. E o alvo aqui é claramente aquelas teorias que têm de postular um poder oculto da matéria, seja aquele inscrito nos objetos exteriores que, assim, seriam a causa original das representações surgidas na mente por meio da atuação dos sentidos, sejam as próprios células nervosas nas quais essa representação nasceria. Nesse sentido, segundo a hipótese defendida por Bergson, "o sistema nervoso, massa material que apresenta certas qualidades de cor, resistência, coesão, etc., talvez possua propriedades físicas não percebidas, mas propriedades físicas apenas. Donde se depreende que seu papel é unicamente o de receber, inibir ou transmitir movimento". 98

O materialismo, na sua tentativa de negar a realidade do espírito, postula, ao contrário, a existência de tais poderes, na medida em que tem de fazer surgir a consciência, que inclui desde a percepção das qualidades sensíveis até os fatos intelectuais mais complexos, apenas da matéria e do jogo de seus elementos. No entanto, se o materialismo afirma tais poderes, afirma, ao mesmo tempo, que as qualidades sensíveis são apenas "fosforescências que seguiriam o rastro dos fenômenos cerebrais no ato da percepção", fazendo, portanto, das qualidades sensíveis, apenas efeitos relativos daquela extensão geométrica que seria a natureza mesma da matéria.

O espiritualismo, por outro lado, ao negar à matéria essas mesmas qualidades sensíveis que seriam apenas aparências subjetivas, representações em um espírito, faria

\footnotetext{
${ }^{98}$ Bergson, H. 1999, p. 75.
} 
dela uma entidade tão misteriosa que seria incapaz de garantir que dela não pudessem surgir tais fenômenos mentais.

Para Bergson, prtanto, a afirmação de que percebemos a matéria em sua própria natureza, o que implica a negação de poderes e virtualidades ocultos, é o que garantiria a independência dos fenômenos do espírito. ${ }^{99}$ Pois, uma vez que a percepção pura da matéria nos dá o que lhe é essencial e que tudo o que se lhe adiciona vem da memória, se Bergson puder provar que essa memória extrapola os mecanismos cerebrais que com ela se relacionam, ele poderá reafirmar, por esta instância que é independente da percepção e que, ao mesmo tempo, se mescla constantemente a ela, a hipótese que sustenta a realidade do espírito. Sendo assim:

\footnotetext{
Uma vez que a percepção pura nos dá a totalidade ou, ao menos o essencial da matéria, uma vez que o resto vem da memória e se acrescenta à matéria, a memória, por princípio, deve ser um poder absolutamente independente da matéria. Se, portanto, o espírito é uma realidade, será aqui, no fenômeno da memória, que devemos entrar em contato experimental com ele. ${ }^{100}$
}

Donde a importância do problema da memória para a teoria bergsoniana. No entanto, a rápida reconstrução das considerações sobre a memória que acabamos de apresentar tiveram apenas o intuito de indicar a perspectiva pela qual Bergson propõe as correções necessárias à sua teoria da percepção pura, correções que possibilitarão que ele se pronuncie sobre a realidade do espírito e, de tal forma, que as relações que enfim serão estabelecidas entre espírito e matéria configurarão, por fim, um dualismo bastante próprio. Deixaremos, no entanto, para a segunda parte desse trabalho as considerações sobre esse dualismo que começa a se configurar na teoria da percepção em relação à qual procuramos centrar nossa análise.

\footnotetext{
99 “A verdade é que não haveria apenas um modo de refutar o materialismo: seria estabelecer que a matéria é absolutamente como ela parece ser." Bergson, H. 1999, p. 76.

${ }^{100}$ Bergson, H. 1999, p. 76-77.
} 


\section{DiÁLOGO ENTRE AUTORES}

campo de imagens / idéias-coisas ${ }^{1}$

Antes de entrarmos mais propriamente nas questões ontológicas tratadas por

Bergson, exploremos ainda um aspecto de sua crítica e observemos se a tese que nos parece central à sua teoria da percepção, a saber, a afirmação de que a percepção nos daria a natureza dos objetos percebidos, não seguiria o mesmo caminho de superação das teorias da representação apontado por Berkeley que, no entanto, é considerado por Bergson como um idealista e, nesse sentido, um dos adeptos dessa teoria da representação que redundaria em um monismo a ser evitado.

Para desenvolver tal hipótese é preciso, em primeiro lugar, distinguir a filosofia de Berkeley daquele idealismo no qual Bergson o filia e pelo qual o critica, ou seja, distinguir a filosofia de Berkeley de um idealismo que se inscreveria entre aquelas filosofias decorrentes do dualismo de tipo cartesiano e que procuraria resolver o problema da representação, que tem suas raízes nesse dualismo, pela supressão de um dos termos em que ele se dá. Ou seja, uma filosofia que, ao rejeitar o caminho da pura abstraç ão, e não tendo encontrado um critério empírico de adequação da representação em relação ao objeto representado, excluísse o objeto e ficasse apenas com a representação, batizando-a de "coisa". Esquecendo-se, portanto, que esta não passaria de

\footnotetext{
${ }^{1}$ As considerações a respeito da filosofia de Berkeley e a comparação que aqui se tentou explicitar entre essa filosofia e a de Bergson, no âmbito das relações entre a crítica à teoria da representação e a ontologia bergsoniana, toma m como base a interpretação canônica de Bento Prado Jr. sobre o tema, especificamente sua afirmação de que o campo de imagens proposto por Bergson seria correlato às idéias-coisas de Berkeley, ambos campos de indistinção primitiva de onde Bergson teria de fazer surgir "tanto a consciência como os seus objetos." Cf. Prado Jr, B. Presença e Campo Transcendental - Consciência e negatividade na filosofia de Bergson. São Paulo, EDUSP, 1989.
} 
uma aparência e, pior, esquecendo-se de que não pode haver aparência sem algo de que haja aparência.

Explicitemos, então, a crítica de Bergson ao pensamento que ele reputa também a Berkeley.

Segundo a análise desenvolvida por Bergson em O Pensamento e o movente, ${ }^{2}$ o problema da percepção da matéria adviria do fato de realismo e idealismo, no qual Berkeley é nominalmente incluído, partirem justamente da distinção entre a percepção e a natureza mesma da matéria. ${ }^{3}$ Segundo o vocabulário da filosofia moderna, a matéria existiria como extensão, no espaço; sua percepção, como representação inextensa, no espírito. Que ou a extensão no espaço ou a representação no espírito seriam a expressão do real, é o que cada sistema se esforçaria então por provar. Nesse sentido e, segundo Bergson, o idealismo de Berkeley negaria substancialidade à matéria porque não poderia conceber algo exterior ao espírito — o qual se dá a conhecer imediatamente — e que, por sua própria exterioridade, não pudesse ser intuído, ou conhecido pelo espírito. Portanto, é a matéria dos realistas, considerada como extensão no espaço, como exterioridade distinta de sua representação interior ao espírito, que Berkeley levaria em consideração e cuja existência negaria. Portanto, mais uma vez, Berkeley partiria dessa distinção entre matéria e representação da matéria para negar um de seus pólos. Sendo assim, negada a matéria como realidade exterior ao espírito, como extensão no espaço, o mundo material se resumiria ao mundo sensível, a matéria a um conjunto de sensações ou representações em uma mente, a idéias, que, por sua peculiaridade mesma, seriam totalmente dadas ao espírito. No entanto, essa forma de fazer a matéria coincidir com aquilo que dela

\footnotetext{
${ }^{2}$ Bergson, 1950.

${ }^{3}$ Ainda que Berkeley tenha sido explícito em afirmar o contrário: "A distinção entre uma idéia e a percepção da idéia tem sido uma das maiores causas de se imaginar a substância material." (PC, 609 e Dialogues, 194-197)
} 
percebemos, além de estar, segundo Bergson, fundada em uma distinção inicial — ainda que posteriormente negada - entre a matéria e sua representação, equivaleria, em última análise, à anulação da matéria como realidade independente, uma vez que ela só existiria como representação em um espírito. Ou seja, é porque eu parto da distinção entre algo que existe independentemente e é inacessível em si — a substância material — e algo que só existe na mente, e é diretamente acessível nas impressões sensíveis causadas por essa substância que, ao negar a falta de acessibilidade da matéria, portanto a impossibilidade de conhecê-la, automaticamente nego essa instância em que ela existe independente do espírito. Portanto, segundo Bergson, para negar a impossibilidade do conhecimento, ou, como sabemos, para se armar contra o ceticismo, Berkeley teria sido obrigado a negar a substancialidade da matéria ou sua existência independente do espírito, mas isso somente porque ele seria caudatário, ainda que de início, da concepção que afirma a dupla realidade da matéria.

Se, ao contrário, segundo a hipótese defendida por Bergson, não considerarmos a matéria como aquela extensão em si mesma impossível de se dar na percepção sensível, e que, portanto, se daria apenas por representação em estados inextensos de uma mente, mas, já de início, a considerarmos como aquele conjunto de imagens próprio à experiência sensível, ou seja, algo que, por definição, pode ser ao menos potencialmente e parcialmente apreendido por uma consciência - parcialidade e potencialidade que, por seu lado, correspondem apenas a relação entre o todo e suas partes —, então não existiria mais diferença de natureza entre a matéria e a percepção da matéria, ou dificuldade em explicar como duas realidades distintas podem se encontrar na percepção ou na consciência da matéria. 
Parece, então, que a identidade de natureza entre a matéria e a percepção da matéria só ganha cidadania se pudermos manter a distinção entre essa percepção e essa matéria em outros termos. Distinção que deve, necessariamente, implicar a independência da matéria em relação àquela realidade que se distingue dela e que atua sobre ela e que reputamos ao domínio do espírito, ou de uma vontade.

Detenhamo-nos assim sobre essa noção de independência e de dependência da matéria em relação ao sujeito de sua percepção, já que a afirmação de uma ou de outra parece demarcar uma divergência intransponível entre a filosofia de Bergson e de Berkeley.

Para Bergson, essa independência da matéria em relação ao sujeito de sua percepção se explicitaria no fato empírico de que o mundo material extrapola nossa percepção dele e de que existiria mesmo se não houvesse nenhuma consciência parcial dele. No entanto, existiria como imagem, ou seja, como algo que, mesmo impercebido, seria passível de percepção. E isso é de fundamental importância, pois afasta radicalmente a concepção de matéria de Bergson daquela defendida pelos realistas, uma vez que estes definem a natureza da matéria justamente em sua distinção em relação à natureza das apreensões por uma consciência, pelas quais ela seria apenas traduzida, representada, mas nunca dada em si mesma.

Ocorre que, por outro lado, ainda que Berkeley não se canse de afirmar a dependência das idéias, ou seja, das coisas, em relação à mente, para ele, no entanto, essas mesmas coisas não são, de forma alguma, criação dos sujeitos pelos quais são percebidas e não desapareceriam se um determinado sujeito de sua percepção desaparecesse. Esse mundo das coisas sensíveis, por outro lado, também extrapola, e na medida da infinitude divina, a percepção de um sujeito, ou, se quisermos, de todos os sujeitos finitos reunidos. Pois, se Berkeley afirma que "tudo o que há no céu e na terra, ou seja, todos os corpos que 
compõem a poderosa máquina do mundo não têm qualquer subsistência exterior a uma mente, que seu ser é ser percebido ou conhecido", ele também afirma,

“consequentemente, quando não são percebidos por mim, e não existem na minha mente ou na de qualquer outro espírito criado, ou não existem de modo algum ou subsistem na mente de um espírito eterno". ${ }^{4}$ Portanto, se Berkeley afirma que o mundo físico é um conjunto de idéias e que, sendo assim, só pode existir em uma mente, mas, ao mesmo tempo, assume que há mais idéias do que as que uma mente pode perceber, ou mesmo que o conjunto dos espíritos finitos pode perceber, uma vez que elas existiriam como "obra" de Deus passível de ser percebida, podemos levantar a hipótese de que sua concepção da dependência desse mundo físico em relação às mentes que o percebem se resume exatamente nisso, em sua possibilidade de ser percebido, em sua possibilidade de ser acessado pelo espírito e, conseqüentemente, no fato de não esconder em si nenhuma realidade inacessível, quanto mais sua verdadeira realidade. E, nisso principalmente, na impossibilidade de que uma realidade tão extremamente unida à nossa seja apenas um simulacro. Nessa acessibilidade pelo espírito da realidade até então chamada de material se fundaria sua nova denominação como idéia e a insistência em afirmá-la como existente em um espírito. Afirmação que, de resto, não pode ser entendida em seu sentido espacial estrito, mas, segundo as próprias palavras de Berkeley, “quando eu falo dos objetos como existindo no espírito ou como impressos nos sentidos, não pretendo ser compreendido em sentido literal, como quando se diz que um corpo existe em um determinado lugar ou que um selo se imprime na cera. Quero apenas significar que a

\footnotetext{
${ }^{4}$ Berkeley, 1979, PHK., § 6; ou ainda DHP, p. 231: “quando eu nego às coisas sensíveis uma existência fora da mente, não estou considerando minha mente em particular, mas todas as mentes. Pois é óbvio que elas têm uma existência exterior à minha mente, uma vez que pela experiência observo que são independentes dela. Há, portanto, alguma outra mente na qual elas existem, durante os intervalos de temp o que se interpõem entre minha percepção delas: quando elas eram percebidas antes de meu nascimento, e deverão ser depois de meu suposto aniquilamento. Verdade que se estende a todos os espíritos finitos; do que se segue necessariamente que há uma Mente eterna onipresente, que conhece e compreende todas as coisas, e que as exibe diante de nossa visão segundo os modos e de acordo com as regras por ele determinadas, as quais chamamos de Leis da Natureza".
} 
mente os compreende ou percebe; e que é afetada do exterior, ou por algum ser distinto dela". 5

Procuremos, então, reconstruir as linhas gerais pelas quais se dá a redução das coisas às idéias efetuada por Berkeley nos Três Diálogos entre Hilas e Filonous, e vejamos se essa hipótese se sustenta. Isso porque, especialmente na argumentação desenvolvida no Primeiro e Segundo Diálogos, Berkeley examinará vários argumentos apresentados pelos materialistas — leia-se filósofos da teoria da representação — em defesa da existência de um objeto exterior à mente, a partir do que, acredito, poderemos melhor compreender o sentido da redução das coisas a idéias e como, a partir dessa redução, a subjetividade dos dados dos sentidos para Berkeley não pode ser considerada no mesmo sentido daquele afirmado nas teorias da representação ${ }^{6}$ e, por oposição, delimitar o tipo de objetividade que lhe é concedida.

Antes, no entanto, é preciso observar que as dificuldades em demarcar tal distinção alimentam-se do fato de Berkeley ter iniciado sua argumentação aparentemente apenas radicalizando, ou levando adiante, o argumento de Locke segundo o qual as qualidades secundárias existiriam somente como dados subjetivos em uma mente. Radicalização que seria levada a cabo pela afirmação da indistinção ontológica entre estas qualidades secundárias e as primárias que, em última instância, estaria fundamentada na crítica berkeleiana à capacidade da abstração. Se, com efeito, é impossível admitir a existência de uma extensão sem cor ou forma, ou do movimento sem corpo movido, o que, por sua vez, implica a mudança de posição entre extensões coloridas com formatos definidos e, como tudo isso, extensões, formas, cores, movimento etc. são conteúdos que se dão a

\footnotetext{
${ }^{5}$ Berkeley, 1979, PHK, § 250.

${ }^{6}$ Sentido explicitado na primeira parte desse texto.
} 
uma mente, então, onde estaria o índice da tal existência que se furtaria a essa percepção e que, portanto, estaria fora da mente?

No entanto, ao raciocinarmos desse modo e, nesse sentido, colocarmos Berkeley como um passo a mais dado na história da filosofia a partir de Locke, corremos o risco de deixar escapar a intenção principal desse movimento e deixarmos de ver que, ao “subjetivar” também as qualidades secundárias, ou seja, ao explicar as qualidades consideradas por Locke como existentes nas coisas exteriores em termos apenas de qualidades sensíveis do tato e da visão que seriam umas o signo das outras, Berkeley efetua muito mais do que uma radicalização de pressupostos, e parece mesmo se desfazer deles, pois ele acaba de se desfazer de nada menos do que da referência exterior constituinte, até então, do objeto dos sentidos e, com isto, da dupla existência do mundo físico, uma no interior outra no exterior da mente. Reduzida a espacialidade a percepções de uma mente, não é o acesso ao exterior que se vê bloqueado, mas a própria existência da exterioridade. No entanto, se essa exterioridade é suprimida, consequentemente se dá um novo sentido à própria interioridade. Esta, não pode mais ser o domínio de introspecção de um sujeito, mas se transforma no ambiente acessível a qualquer sujeito e independente de cada um deles em particular. Assim, imediatamente após a redução das coisas às idéias, surge a necessária presença de uma consciência onipresente na qual todas essas idéias ganhariam objetividade (voltariam a ser "coisas"). Não mais, obviamente, aquela objetividade da coisa una à qual nossas variadas representações se remeteriam, mas a objetividade que é, iminentemente, independência dos dados dos sentidos em relação ao sujeito que os percebe, e que se insere, portanto, nas próprias "representações" que, em conjunto, formam um objeto. 
Com efeito, mesmo a redução das qualidades secundárias ao universo mental em Berkeley se dá por razões e num sentido diferente daquele da filosofia da representação como um todo e de Locke em particular. Para estes, que tinham o objeto uno exterior como ponto de fuga do conhecimento, as qualidades eram subjetivadas, ou entendidas como percepções que se davam no interior de sujeitos particulares, devido a sua relatividade em relação àquele objeto uno anteriormente colocado. Pois os argumentos céticos estavam à mão, seja para se servir deles e problematizar a possibilidade de conhecimento, seja para refutá-los. Para Berkeley, ao contrário, a redução dessas características dos objetos físicos ao universo mental não se dá por sua relatividade — mesmo porque tal relatividade não se coloca, pois não se coloca o objeto uno exterior —, mas pelo simples fato da identificação absoluta entre essas características e sua percepção por uma mente. Assim, Berkeley não têm em muita conta os argumentos céticos, mesmo quando estes aparentemente levariam água para o seu moinho, o que parece ficar claro em uma passagem dos Princípios, quando os utiliza para mostrar sua possibilidade de aplicação também às qualidades primárias ${ }^{7}$ e imediatamente reconhece sua pouca serventia, uma vez que tais argumentos "não provam que não há extensão ou cor em um objeto exterior, mas que não podemos saber pelos sentidos qual a verdadeira extensão ou cor do objeto". ${ }^{8}$ Ao que, então, ele imediatamente acrescenta, "mas os argumentos acima mencionados mostram plenamente que é impossível que qualquer cor ou extensão, ou qualquer outra qualidade sensível possa existir em um objeto não-pensante fora da mente, ou, na verdade, que possa haver algo como um objeto exterior". ${ }^{9}$ Portanto, a redução do físico ao mental, pretendida por Berkeley, se dá segundo um argumento que se distingue daqueles apresentados pelos céticos e aos quais os modernos procuraram responder,

\footnotetext{
${ }^{7}$ Berkeley, 1979, PHK, § 14.

${ }^{8}$ Berkeley, 1979, PHK., \& 15.

${ }^{9}$ Berkeley, 1979, PHK, $\$ 15$.
} 
alguns, assumindo a relatividade de determinadas qualidades dos objetos pela subjetivação destas e pela conseqüente distinção entre o objeto físico e sua percepção por uma mente. E que argumento seria este? Justamente o da redutibilidade de todo objeto sensível — aquele que, segundo sua própria definição, é percebível imediatamente pela visão, audição, tato, olfato e paladar - a essas qualidades físicas. Não se trata, portanto de um argumento propriamente dito, mas, segundo Berkeley de um conhecimento intuitivo, na evidência do princípio fundador de sua doutrina, segundo o qual o ser das coisas — e, como "coisas" devemos entender tudo o que não é espírito — está dado naquilo que se percebe delas, portanto a evidência da identidade entre existência física, material, sensível, como queiramos, e percepção. ${ }^{10}$ E não foi o que Berkeley disse desde o início ao afirmar o esse é percipi como princípio de seu imaterialismo? Não é por acaso que logo no primeiro parágrafo dos Princípios, Berkeley tenha enumerado esses sentidos e as qualidades a eles correspondentes e tenha deixado explícito que os objetos são constituições que não vão além dessa coleção de qualidades. ${ }^{11}$

Se se trata dos objetos, aqueles que são imediatamente percebidos pelos sentidos, e Berkeley insiste em se colocar de acordo com seu interlocutor a esse respeito, ${ }^{12}$ tudo se reduz a percepções. Não há nenhuma característica positiva que possamos dar ao mundo físico que não se resolva nos elementos aos quais temos acesso pelos sentidos. Não há nada, nessa percepção, que remeta a uma substância inerte que pudesse ser semelhante a ela, ou seu substrato e que não devesse também, ser passível de ser reduzido a sensações.

\footnotetext{
${ }^{10}$ Berkeley, 1979, PHK., §3.

${ }^{11}$ Berkeley, 1979, PHK., $\$ 1$ “Assim, por exemplo, observados em conjunto certa cor, sabor, cheiro, figura e consis tência, foram consideradas uma coisa distinta, significada pelo nome maçã."

12 "Pois o que são os objetos acima mencionados além de coisas que percebemos pelos sentidos, e o que percebemos além de nossas próprias idéias ou sensações; e não repugna que uma ou uma combinação delas possam existir impercebidas?" in Berkeley, 1979, PHK, §4; DHP, p. 174.
} 
Como também não há qualquer possibilidade de algo inativo ser causa do que quer que seja, no caso, de sensações.

Posto, então, que ele parte da evidência desses objetos dos sentidos, evidência que reside exatamente no fato de serem dados, conteúdos explicitados, nada que fosse menos evidente que eles próprios poderia por em risco sua realidade. Mas é justamente o que ocorre. A hipótese de um objeto exterior e imediatamente inacessível põe em questão a realidade daquilo que é imediatamente dado. ${ }^{13}$ Há então que se demonstrar não apenas que essa hipótese não é sustentável de qualquer forma que ela nos tenha sido apresentada, ainda que tal demonstração não fosse realmente necessária se nos ativéssemos à evidência do princípio anterior. Ocorre que a claridade de tal evidência está coberta por camadas e camadas de "poeira sábia" que é preciso remover.

Assim, a cada um dos argumentos apresentados pelos materialistas, e que se baseiam no raciocínio segundo o qual, sem tal existência exterior à mente o mundo físico percebido por essa mente perderia sua objetividade, em outras palavras, os objetos dos sentidos perderiam sua realidade, Berkeley responde com as inúmeras falácias e contradições que a hipótese do objeto exterior implica e que, ao contrário, tal realidade do mundo físico é dada na apreensão direta dos vários aspectos dos objetos sensíveis percebidos pelas mentes e subsistentes na mente divina.

\footnotetext{
${ }^{13}$ Berkeley, G. 1979, PHK, §§ 87,88. “ Cor, figura, movimento, extensão e outras, consideradas apenas como sensações na mente, são perfeitamente conhecidas, nelas nada é impercebido. Mas consideradas notas ou imagens que se referem a coisas ou arquétipos existentes fora da mente, arrastam-nos ao ceticismo. Temos as aparências e não a realidade das coisas. Que sejam extensão, figura, movimento ou alguma coisa real e absolutamente ou em si não podemos sabê-lo mas somente a sua proporção ou relação com os nossos sentidos. Permanecendo iguais as coisas e variando as nossas idéias, não alcançamos determinar qual das idéias ou se alguma representa a verdadeira qualidade da coisa. E assim tudo quanto vemos, ouvimos e sentimos pode ser fantasma ou quimera vã, e não se ajustar com as coisas reais da nossa rerum natura. Todo esse ceticismo provém de supor uma diferença entre coisas e idéias e que as primeiras subsistem fora da mente ou impercebidas. Fácil fora alongar este assunto e mostrar como os argumentos dos céticos dependem sempre da suposição de objetos externos. (...) Supondo a existência real de seres impensantes, diferentes de serem percebidos, não só nos é impossível conhecer-lhes a natureza mas até saber que existem. Por isso vemos filósofos duvidarem dos sentidos, duvidarem da existência do céu e da terra, do que vêem ou sentem e até de seu próprio corpo. E depois desta faina e luta de pensamento, são forçados a reconhecer a dificuldade de alcançar conhecimento demonstrativo e evidente da existência das coisas sensíveis. (...)"
} 
Com efeito, Berkeley explora à exaustão as falácias que se seguem à pressuposição da realidade exterior. E a cada exame, sua posição inicial é reafirmada e se distingue, tanto da dos filósofos modernos quanto da dos céticos que, para ele, são semelhantes em sua suposição da dupla existência do objeto sensível pela qual impossibilitam nosso acesso a realidade do mundo e, portanto, impossibilitam o conhecimento. Examinemos então alguns momentos em que esse embate de razões se explicita e vejamos que esclarecimentos podem nos dar em relação não só a face crítica mas também positiva do imaterialismo de Berkeley.

\section{Hilas e Filonous}

No final de sua longa argumentação em favor da redução das qualidades tanto primárias quanto secundárias ao universo mental, na primeira parte do Primeiro Diálogo ${ }^{14}$, Berkeley iniciará uma crítica retrospectiva das hipóteses apresentadas em favor da existência do objeto sensível e que, portanto, teriam sido apresentadas sem levar em conta a redução radical que acaba de ser efetuada e, nesse sentido, continuariam afirmando uma distinção entre o objeto material e a percepção sensível do objeto, esta na mente e aquele exterior à mente. Com efeito, após ter anuído à argumentação de Filonous em favor da inseparabilidade das qualidades primárias e secundárias pela admissão de que, se estas estão na mente (Locke), aquelas também estarão, Hilas — o oponente materialista, no Diálogo, do imaterialista Filonous - , se ressente de que, assim fazendo, estaria negando realidade a essas qualidades sensíveis e, com elas, ao mundo físico em

\footnotetext{
${ }^{14}$ Berkeley, 1979, DHP., p. 171-194.
} 
geral. Assim, para garantir a realidade do mundo físico, Hilas retrocede na argumentação e lança mão, num movimento antilockeano, da distinção entre a real existência das qualidades sensíveis nas coisas e sua percepção, por uma mente, que se daria através de um ato. Assim, surge, como um primeiro fundamento da suposição da dualidade a ser examinado, a pré-suposição de uma atividade do espírito que seria a sensação, nele, daquilo que existiria realmente no objeto: "H. — Por exemplo, há vermelho e amarelo nesta tulipa. Mas o ato de perceber essas cores está em mim apenas, e não na tulipa". ${ }^{15}$ Tentando recuperar com seu interlocutor a redução que acabaram de fazer, Filonous argumenta que a tulipa, enquanto objeto da visão e, nesse sentido, nada mais do que uma extensão que coexiste com uma determinada cor e forma, ${ }^{16}$ só pode existir como uma visão, portanto, em uma mente, ainda que se deva admitir que esta visão seja independente de uma ou outra mente em particular. Assim, dizer que há algo que está na tulipa, e não está na visão da tulipa e que, portanto, não está em uma mente, é um contrasenso. $^{17}$ No entanto, uma vez que a redução já havia sido abandonada por Hilas, como mostra a própria distinção por ele proposta, Berkeley não se furtará a procurar outros caminhos para comprovar as conclusões anteriores. Decide-se , portanto, a examinar sem levar em conta também ele a redução feita anteriormente - que atividade existiria na sensação que pudesse, assim, distingui-la do objeto sentido e a partir da qual, portanto, se pudesse afirmar a real existência das qualidades sensíveis fora da mente em uma substância não-pensante. ${ }^{18}$ No entanto, a análise da percepção das cores e dos perfumes leva Filonous e Hilas a concluírem que, se há alguma atividade implicada na percepção, esta é apenas aquela de uma vontade que a antecede, possibilitando-a, mas que a própria

\footnotetext{
${ }^{15}$ Berkeley, 1979, DHP, p. 194.

${ }^{16}$ Berkeley, 1979, DHP, p. 195: "F. - O que você quer dizer é que o vermelho e o amarelo coexistem com a extensão, não é?"

${ }^{17}$ Berkeley, 1979, DHP, p.195.

${ }^{18}$ Berkeley, 1979, DHP, p. 195.
} 
percepção é totalmente passiva: "F.: — Assim, não está em seu poder abrir os olhos, ou mantê-los fechados; dirigi-los para um lado ou outro? (...) Mas depende igualmente da sua vontade, ao olhar esta flor perceber branco ao invés de qualquer outra cor? Ou, ao dirigir seus olhos abertos para a imensidão do céu, você pode evitar ver o sol? Ou ainda, seriam a luz e a escuridão efeitos de sua vontade? (...) Em relação a isso você é totalmente passivo". 19

Hilas, no entanto, mesmo não podendo deixar de concordar com o caráter passivo da percepção, não se atreve a reputá-la a uma substância externa insensível. Para Filonous, tal passividade que está no objeto percebido e na percepção, dado que são uma e a mesma coisa, é mais um signo da indistinção entre a percepção e objeto sensível, ou, entre as idéias e as coisas. Com efeito, a atividade, no conjunto da doutrina de Berkeley, não será aquilo que distingue a percepção do objeto percebido, mas o ser que percebe de sua percepção, ou, se quisermos, o espírito do mundo sensível (distinção que será desenvolvida adiante).

Prosseguindo em sua "faxina” epistemológica, Filonous-Berkeley examinará o próximo argumento materialista apresentado por Hilas que, em mais um esforço para conceder realidade às coisas sensíveis, levanta uma segunda hipótese, segundo a qual, considerando tais coisas sensíveis como modos ou qualidades, estas teriam necessariamente sua realidade dependente de um substratum material. ${ }^{20}$ No entanto, por meio de uma análise semântica, Filonous faz ver a Hilas que o termo substrato, tanto considerado como suporte quanto como substância só têm sentido em sua significação literal, ou seja, aquela que necessariamente se remete às qualidades sensíveis implicadas nas definições dos termos, que se remetem a “estar sob, subjazer”. Assim, para estar sob

\footnotetext{
${ }^{19}$ Berkeley, 1979, DHP, p. 196.

${ }^{20}$ Berkeley, 1979, DHP, p. 197-199.
} 
as qualidades sensíveis, e, o que importa para Hilas, para além delas, seria preciso, ao menos em relação aos objetos visíveis, estar sob a extensão visível. Mas como é possível estar sob a extensão sem ser também extenso? E se tal acepção do termo é por demais prosaica, é possível conceder-lhe outra? Filonous acredita que não, e Hilas não consegue apresentar-lhe nada que o convença do contrário. É impossível aqui não nos remetermos às considerações sobre a linguagem que são parte integrante do método berkeleiniano e que denunciam os erros inerentes ao fato de usarmos determinada palavra, acreditando que ela se refira a uma idéia, quando não se refere à idéia alguma. Isso ocorre com os termos suporte ou substância quando fazem parte da definição de matéria como substratum de acidentes. Se quisermos utilizá-los para provar a necessidade da existência de algo exterior à mente, é porque acreditamos que seu significado nos remete a essa existência exterior. No entanto, não precisamos de um exame muito profundo dos termos para observarmos que eles justamente só têm significado se os relacionarmos a idéias sensíveis, justamente o que se queria evitar, uma vez que só podemos compreender o sentido de "estar sob, subjazer, suportar" remetendo-nos à idéia sensível de extensão.

Segundo Filonous, no entanto, nenhuma dessas considerações teria sido necessária se Hilas tivesse atentado para o fato absoluto da existência das qualidades sensíveis e que sua realidade não pode ser dependente da suposição de um suporte material, uma vez que tais qualidades sensíveis são dadas imediatamente e tal suporte não é dado nem imediata nem mediatamente, ou seja, se tivesse atentado para o absurdo de acreditar poder conceder realidade às qualidades sensíveis por meio de um fundamento inconcebível dessa realidade. Assim, Filonous chama a atenção de Hilas sobre tal fato: "você afirmou que não poderia conceber como qualidades ou acidentes poderiam existir realmente sem conceber ao mesmo tempo um suporte material para eles. (...) Quer dizer, 
quando você concebe a existência real das qualidades, concebe ao mesmo tempo algo que não consegue conceber". 21

O tema fundamental da conceptibilidade é retomado uma vez mais quando, na seqüência da argumentação, Hilas lança mão do que acredita ser uma terceira possibilidade de fundamentação da existência de qualidades sensíveis exterior ao espírito, propondo que o problema dessa existência estivesse na abordagem de cada uma das qualidades separadamente, o que não ocorreria se fossem tomadas em conjunto. ${ }^{22}$ Bem, nessa terceira recaída de Hilas, Filonous perde um pouco a compostura e acusa Hilas de não estar sendo sério, uma vez que eles já haviam concluído, entre outras coisas, justamente que as qualidades secundárias só podem existir umas unidas às outras, e em uma mente, onde também estariam as qualidades primárias, por ser impossível considerar a estas separadas daquelas. O fato - e o que nos interessa aqui - é que Filonous propõe deixar de lado toda a sua argumentação anterior e aceitar o ponto de vista de Hilas sobre a existência de objetos exteriores à mente se ele assim puder conceber um deles que seja. $^{23}$ Hilas responde que não há tarefa mais fácil, uma vez que é perfeitamente possível conceber árvores e casas existindo sem que haja ninguém para percebê-las. Ao que Filonous retruca com a explicitação da incoerência na fala de Hilas que afirma a existência de coisas exteriores à mente no momento mesmo em que ele as têm em sua própria mente, ao concebê-las impercebidas. Mais uma vez, portanto, Berkeley está afirmando a força de seu princípio, que bastaria por si só para sustentar o seu imaterialismo e, o que nos importa aqui, contra os contra-sensos com os quais a filosofia da representação quer refutá-1o. Hilas ainda prossegue em suas tentativas de fundamentar

\footnotetext{
${ }^{21}$ Berkeley, 1979, DHP., p. 199.

${ }^{22}$ D.H.P, p. 200.

${ }^{23}$ DHP., 200: "Se você puder conceber que qualquer mistura ou combinação de qualidades, ou qualquer objeto sensível, possa existir fora da mente, então eu concordarei que realmente é assim.”
} 
uma existência exterior à mente lançando mão da hipótese que afirma um objeto material concebido como o original mediatamente conhecido por suas cópias, estas, as percepções sensíveis que se dão imediatamente à mente, hipótese que não examinaremos por pouco acrescentar aos casos acima apresentados. Iremos diretamente para a hipótese apresentada já no início do Segundo Diálogo e que pode ser considerada como a figura emblemática da teoria da representação, uma vez que procura apresentar um certo "mecanismo" que dê conta da ação da matéria sobre o espírito no momento da produção das idéias sensíveis. Berkeley irá desenvolver então uma versão anterior daquela crítica retomada por Bergson em Matéria e Memória, e que se baseia na falta de sentido em considerar o cérebro, idéia entre idéias — ou, como quer Bergson, imagem entre imagens — como produtor de idéias.

Sigamos a apresentação da hipótese por Hilas:

\footnotetext{
H.: Supõe-se que a alma resida em alguma parte do cérebro, na qual os nervos se originam e de onde se estendem para todas as partes do corpo; e que objetos exteriores, pelas diferentes impressões que fazem nos órgãos dos sentidos, comunicam certos movimentos vibratórios aos nervos, que, estando repleto de espíritos animais, os propagam até o cérebro ou sede da alma, a qual, de acordo com as várias impressões ou traçados feitos por esse modo no cérebro, é afetada por diferentes idéias.
}

Ao que Filonous responde, não sem antes ter se certificado com Hilas de que o cérebro ao qual ele se refere é uma coisa sensível e, portanto, imediatamente perceptível:

\footnotetext{
F.: Além dos espíritos, tudo o que conhecemos são nossas próprias idéias. Portanto, quando você diz que todas as idéias são ocasionadas por impressões no cérebro, você concebe ou não este cérebro? Se concebe, então você fala de idéias impressas em uma idéia, causando aquela mesma idéia, o que é absurdo. Se você não concebe, você fala ininteligivelmente, sem formar qualquer hipótese razoável. ${ }^{24}$
}

É evidente, portanto, que todo o modelo representacionista é aqui criticado. Se nervos e cérebro só podem ser entendidos enquanto extensões determinadas por formas,

\footnotetext{
${ }^{24}$ Berkeley, 1979, DHP., p. 208-209.
} 
cores e texturas é porque são impressões de uma mente. Como então, estas impressões poderiam causar todas as demais impressões dessa mente? Ou, ainda, como poderiam elas causar o que quer que seja, dada sua natureza inativa? E aqui, a comparação pontual com Bergson parece profícua para demonstrar a força do argumento. Pois, quer nervos e cérebro sejam considerados idéias interiores a uma mente, ou imagens exteriores tornadas conscientes pela ação de uma mente, eles são, evidentemente, da mesma "natureza" dos demais objetos físicos por meio dos quais, portanto, estes não podem ser dados ou estar contidos.

Berkeley e Bergson

Retomemos, dos argumentos que acabamos de expor, os elementos necessários para abordarmos mais concretamente a hipótese da qual partimos sobre a distinção de sentido entre a subjetividade inerente à teoria da representação e aquela apresentada pelo imaterialismo de Berkeley, bem como da noção correlata e oposta de objetividade, com o que, ao distinguir assim o pensamento de Berkeley, supomos ser possível uma aproximação com posturas mais contemporâneas.

De início, como vimos, não há, para Berkeley, um ato de percepção que se oporia ao seu conteúdo, de um lado porque a percepção, propriamente dita, não envolve um ato, mas um agente que, no momento da percepção é passivo. Portanto, percepção e conteúdo da percepção formam uma unidade impossível de ser distinguida e cuja realidade não pode ser contestada por se tratar de um dado. Se é assim, se tal percepção e 
percepcionado não podem ser distinguidos, e se pressupõem um agente no qual ocorram, não há nada que, ao mesmo tempo, sustente a hipótese de uma substância inativa a partir dessa percepção, uma vez que tal substância introduziria uma distinção que se mostrou inconcebível. Por outro lado, portanto, a passividade da percepção, que aponta para a inatividade do sujeito ativo no momento da percepção, só pode ser explicada por um outro Ser Ativo, de maior potência, que aja sobre aquele ser ativo de menor potência. E é desse modo que propomos a leitura da passagem, que então se segue, no Segundo Diálogo, àquelas examinadas acima, quando Filonous, da inatividade do espírito que percebe e, portanto, da independência daquilo que ele percebe em relação a sua vontade, afirma a existência de um outro espírito mais poderoso que explicaria a realidade dada dessas coisas percebidas. Assim, após reafirmar a realidade das percepções e do mundo físico que elas constituem, pela descrição que enfatiza a evidente superioridade de escala entre essas idéias sensíveis e aquelas que qualquer espírito finito pudesse suscitar, ${ }^{25}$ (num uso bastante peculiar de retórica explorado em outro diálogo de Berkeley, o Alchiphron) Filonous conclui pela existência de Deus.

\footnotetext{
F.: Para mim é evidente, pelas razões às quais você deu assentimento, que as coisas sensíveis não podem existir em outro lugar a não ser em uma mente ou espírito. Do que eu concluo, não que não tenham existência real, mas que, ao ver que não dependem do meu pensamento, e que existem independentemente de serem por mim percebidas, deve haver alguma uma outra mente na qual elas existem. Portanto, tão certo quanto a existência real do mundo sensível, é a de um espírito onipresente que o contém e suporta.
}

${ }^{25}$ DHP., 210-211. 
Mas isso não é o que também supõe qualquer filósofo que assuma a existência de um princípio criador, origem e fundamento de tudo quanto exista, seja material ou espiritual, e também daqueles filósofos que têm uma concepção realista da matéria, como Descartes ou Locke, ou seja, quando esse espírito em relação ao qual a matéria depende é Deus, como o próprio Hilas retruca?

H.: Ora, mas isso é o que eu e todos os cristãos sustentamos! Mais do que isso, é o que sustentam todos aqueles que acreditam que há um Deus, e que ele conhece e abarca todas as coisas.

Ao que, no entanto, Filonous faz notar uma distinção fundamental

F.: Mas é justamente nisso que reside a diferença! Os homens geralmente acreditam que todas as coisas são conhecidas e percebidas por Deus, porque acreditam que há um Deus, enquanto eu, ao contrário, concluo imediata e necessariamente a existência de Deus porque todas as coisas têm de ser percebidas por ele. $^{26}$

E aqui apresenta-se o que podemos considerar como mais uma oposição em relação às posições assumidas pela filosofia moderna, agora, especificamente, uma crítica à necessidade da prova da existência de Deus em Descartes. Ora, pois não é a filosofia que afirma a independência da matéria em relação ao espírito que tem de provar a existência de Deus para então garantir a realidade do mundo físico? E não é justamente o idealista Berkeley que, ao contrário, nos oferece uma prova da existência de Deus a partir da realidade do mundo físico? Estamos diante de um simples jogo de cena, ou os papéis

\footnotetext{
${ }^{26}$ Berkeley, 1979, Three Dialogues between Hylas and Philonous, p. 212.
} 
se mostram por direito invertidos quando os parâmetros do pensamento começam a se alterar em relação ao que lhes precedia?

De fato, entra em jogo aqui uma possível problematização levantada ${ }^{27}$ em relação justamente a essa passagem, quando Berkeley parte da observação de que ele não é causa de suas idéias sensíveis, passa pela afirmação de que, nesse sentido, elas existem independentes de sua mente, até chegar à conclusão de que há uma outra mente na qual elas existem. Com efeito, o terceiro passo poderia ser considerado anterior ao segundo, ou seja, eu não poderia afirmar a existência exterior ou independente das idéias sensíveis se não pressupusesse que elas existem em uma outra mente, portanto, que existem na mente de outro espírito, etc... No entanto, parece-me que a hipótese de que as idéias existam na mente de Deus (3) é tanto posterior à observação de sua independência (2) quanto do fato de não serem causadas por mim (1), uma vez que, entre (2) e (3) há a hipótese de que essa independência das percepções seja sinal justamente da distinção entre essa percepção e aquilo que é percepcionado e que estaria em uma substância nãopensante exterior ao espírito, aliás, a hipótese materialista que deve ser afastada para que (3) se evidencie como a verdadeira. O que é feito pela demonstração da inconceptibilidade dessa substância exterior não-pensante, uma vez que, por um lado, é impossível dar-lhe qualquer conteúdo positivo, como o da extensão ou movimento no espaço, dado que a inteligibilidade desses conceitos depende de sua redução a conteúdos sensíveis, portanto, no âmbito do universo mental; por outro lado, é impossível dar-lhe qualquer conteúdo relacional, dado que, na noção de suporte, está implícita a de extensão, e cairíamos no caso acima. A última possibilidade seria considerá-la como causa, o que, no entanto, implicaria uma atividade, que só poderia ser encontrada em

\footnotetext{
${ }^{27}$ Noel Fleming. "The tree in the quad”, American Philosophical Quarterly, jan. 1985.
} 
uma mente e não em uma substância inerte. Assim, parece bastante plausível sustentar que, no âmbito da argumentação desenvolvida por Berkeley, a existência de Deus como suporte do mundo sensível não seria anterior, mas posterior, ou, no máximo, concomitante ao fato de não haver vontade do ser que percebe envolvida na percepção sensível e da impossibilidade de que essa percepção sensível fosse causada por uma substância não-pensante — tríade de proposições que poderiam muito bem caracterizar o pensamento berkeleiano.

Resta ainda ressaltar um último ponto em relação a essa objetividade concedida pela mente divina aos objetos do mundo físico na filosofia de Berkeley, ou seja, a afirmação, baseada nas passagens em que Berkeley se refere à existência dos objetos sensíveis na mente de Deus, de que tais objetos seriam pensados por Deus e de alguma forma acessados pelos espíritos finitos, e não que seriam apenas causados por Deus diretamente na mente desses seres finitos. Com efeito, se admitíssemos essa última hipótese, o mundo físico seria apenas causalmente independente dos espíritos finitos e não existencialmente dependente, como assegura a hipótese que defendemos segundo as próprias palavras de Berkeley:

(...) Pois ainda que tenhamos afirmado que os objetos dos sentidos nada mais são que idéias que não podem existir impercebidas, no entanto, não se pode concluir daí que só tenham existência quando são percebidos por nós, uma vez que pode haver algum outro espírito que os perceba enquanto nós não os percebemos... ${ }^{28}$

(...) consequentemente, quando não são percebidos por mim, e não existem na minha mente ou na de qualquer outro espírito criado, ou não existem de modo algum ou subsistem na mente de um espírito eterno.

\footnotetext{
${ }^{28}$ Berkeley, G. 1979, Principles, Parte I, $\S 45$ e 48.
} 
(...) Há, portanto, alguma outra mente na qual elas existem, durante os intervalos de tempo que se interpõem entre minha percepção delas: quando elas eram percebidas antes de meu nascimento, e deverão ser depois de meu suposto aniquilamento. ${ }^{29}$

Sendo assim, nem o mundo físico ou, se quisermos, a matéria, é subsumida ao espiritual, nem o espiritual pode ser confundido com a matéria. A "matéria" — esse conjunto de idéias - é uma realidade, e se distingue do espírito, mas interage com ele ou porque é por ele gerada, ou porque é por ele acessada em sua própria realidade. Ou, para não ferirmos o espírito da letra de Berkeley, a matéria é a natureza, esse conjunto de idéias que Deus concebeu para se comunicar com sua dileta criatura, e, por isso, ela existe para a sua criatura, nada nela é em princípio inacessível à sua criatura que, por ser imagem e semelhança de seu criador é, essencialmente, espírito.

Portanto, se voltarmos a considerar a questão da dependência da matéria em Berkeley, esta se dá em relação ao Espírito, em relação ao qual também os espíritos finitos são dependentes; ambos são dependentes, ainda que de formas diferentes, ambos existem, ainda que também de formas diferentes, mas é nessa diferença mesma de formas de existência, quer dizer, de naturezas, que eles podem se encontrar. Nesses termos, acredito que Berkeley não teria dificuldades em aceitar a existência da matéria, se essa fosse considerada como uma forma peculiar de existência que nada pode esconder subjacente a si, uma vez que a própria peculiaridade de sua existência é se dar a conhecer, e se dar a conhecer a algo que justamente tenha a capacidade do conhecimento, donde se estabelece

\footnotetext{
${ }^{29}$ Berkeley, 1979, Parte I, § 6.Diálogos, p. 231.
} 
a relação de dependência, ao menos até aqui, unilateral. ${ }^{30}$ Concepção de matéria que em nada feriria o princípio fundador da filosofia de Berkeley, esse é percipi ou percipere.

Entendido dessa forma o percipi de Berkeley, e resolvida, ao nosso ver, a questão da independência ou dependência da matéria em relação ao espírito nos termos da acessibilidade da realidade da matéria, podemos sustentar que há uma proximidade bastante concreta entre a concepção de "matéria" de Berkeley e a de Bergson expressas nas figuras, respectivamente, da "idéia" e da "imagem". O que nos leva de volta à questão inicialmente apresentada sobre a discordância entre Bergson e Berkeley no que diz respeito ao "lugar" da percepção. Devemos considerar, no entanto que, ainda que Bergson afirme que nossa percepção está nas coisas e, Berkeley, que nossa percepção só pode estar onde estão as idéias, ou seja, em um espírito, ambos consideram que as coisas, imagens, ou idéias, estão todas nesse campo de coisas, idéias, ou imagens que transcende a esfera individual do espírito, esfera individual que, no entanto, ao se apresentar como um recorte ou uma perspectiva assumida por esse espírito no interior desse campo que o transcende, é apreendida em sua própria natureza.

Portanto, quando Bergson afirma que a percepção está nas coisas percebidas e não na mente, ele nada mais está fazendo do que criticar essa distinção entre a matéria e sua representação, uma vez que essa distinção faz das percepções “alucinações verdadeiras”, ou seja, estados do sujeito projetados para fora dele, quer esses estados sejam entendidos como a única realidade existente, quer como apenas semelhantes a ela.

Ocorre que, por outro lado, vimos que, quando Berkeley afirma que todo o mundo sensível só pode existir em uma mente, nada nos autoriza a identificar essa mente àquela

\footnotetext{
${ }^{30}$ Berkeley, Principles, $\S \S 89$ e 90 "As idéias impressas nos sentidos são coisas reais ou existem realmente; não o negamos, mas negamos que existam fora do espírito percipiente ou que sejam semelhanças de arquétipos exteriores ao espírito..."
} 
realidade inextensa que caracteriza cada sujeito individualmente e cujos estados seriam posteriormente exteriorizados e que, portanto, produziria representações à maneira de alucinações. Como vimos, mente, para Berkeley, significa tanto os sujeitos da percepção quanto aquela espiritualidade superior, e percepção significa a consciência, por esses sujeitos percipientes, do mundo sensível, que, sustentado por aquela espiritualidade superior, é composto por realidades exteriores e acessíveis, em si mesmas, a cada indivíduo. Assim a mesma identidade estabelecida por Bergson entre a percepção e as coisas percebidas é mantida em Berkeley, como também a realidade dessas coisas percebidas como exterior a cada sujeito da percepção.

Pois não é justamente essa distinção entre a matéria e a percepção da matéria e a conseqüente divisão entre realidade material, exterior ao espírito, e realidade sensível, interior ao espírito que Berkeley havia negado ao afirmar que o mundo físico se resume àquilo que pode ser percebido por uma mente, se levarmos em conta que, isso que é percebido por uma mente nada tem a ver com estados da mente causados por uma substância exterior desconhecida e posteriormente exteriorizados na forma de representações? Pois, como citamos acima, se Berkeley assume que o mundo físico resume-se a idéias em uma mente, de modo algum isso significa que essas idéias são produzidas nessa mente, mas que são apreendidas por ela a partir do exterior, porque é no exterior que está sua fonte, um espírito infinito que as apresenta. Nesse sentido, portanto, Berkeley não poderia dizer juntamente com Bergson que a percepção das coisas ocorre nelas mesmas, ou seja, que a percepção de uma idéia está na apreensão da própria idéia e não em uma duplicação, na mente, de uma realidade exterior?

E, nesse sentido, não poderíamos considerar que a afirmação de Bergson de que nossa percepção está nas coisas corresponde à afirmação de Berkeley segundo a qual tudo o 
que percebemos só pode estar em uma mente, um vez que entendamos essa mente como aquele campo de coisas, idéias, ou imagens que transcende a esfera individual do espírito, esfera individual que, no entanto, ao se apresentar como um recorte ou uma perspectiva assumida por esse espírito no interior desse campo que o transcende, apreende-o em sua própria natureza ?

Se, então, essas considerações, que foram aqui apenas apontadas, puderem ser confirmados em seu desenvolvimento mais estrito, acredito que poderiam fortalecer a hipótese pela qual tanto Berkeley quanto Bergson figurariam lado a lado em uma corrente de pensamento que rompe com a gnosiologia moderna, a qual é concebida a partir da distinção a priori entre sujeito e objeto do conhecimento e da filosofia da representação decorrente dessa distinção. E que a estratégia mobilizada por ambos seria, a partir de uma análise da percepção, demonstrar, por um lado, a incongruência existente em supor essa percepção como um tipo de duplo de algo por natureza imperceptível, e, por outro lado, explicar tal percepção sempre em termos de ação e, nesse sentido, de espiritualidade. No caso de Bergson, a ação do espírito, que se anuncia a partir já da indeterminação introduzida pelos organismos vivos, sobre um universo de imagens que é comparado a uma grande consciência adormecida. No caso de Berkeley, a ação de Deus sobre os espíritos finitos. Com efeito, uma vez que os problemas decorrentes do dualismo estrito, que colocava de um lado uma extensão sem forma e de outro uma consciência sem conteúdo se esvaíram, toda teoria da percepção de Bergson seria a proposta de solução do problema de como se daria efetivamente a ação da espiritualidade na extensão que configura a percepção, o que implica a explicitação de todos os mecanismos de atuação da memória pelos quais aquele fundo de objetividade, que assegura a realidade de toda percepção, recebe os aportes da subjetividade (ao mesmo tempo em que se 
configuram concretamente, ou se individualizam, se subjetivizam). Berkeley, ao

contrário, não se teria dado esse trabalho. De resto, como procurar alcançar os meandros pelos quais a mente divina atinge, com os efeitos de sua atividade, cada uma das mentes individuais na percepção? Bastaria aqui mostrar o absurdo em afirmar a hipótese de que essa ativi dade residisse no que é inerte.

Fiquemos portanto com o acordo entre Berkeley e Bergson acima sugerido, o qual, no final das contas, não terá sido em vão se, por ele, conseguirmos estabelecer um ponto comum entre ambas filosofias, a saber, a caracterização desse aspecto negativo da intuição original inerente, segundo Bergson, a qualquer filosofia, aquela intuição que justamente impediu tanto Berkeley quanto Bergson de aceitar a irrealidade do mundo que nos cerca, resultado aparentemente incontornável dos dualismos de tipo cartesiano. Irrealidade que os levava a dizer: Impossível, toda vez que com ela se deparassem. ${ }^{31}$ Se assim for, se conseguirmos defender que Berkeley e Bergson partem dessa mesma intuição negativa e que ela desenha desde o início um universo distinto daquele do qual partem as teorias da representação, conseguiremos defender também que Berkeley tem em mente parâmetros que não se adéquam à estas teorias, e que, nesse sentido, ele não amputa seus pressupostos, nem se perde em um idealismo fantasioso, mas transforma os pressupostos dos quais havia partido. Teremos então dado um primeiro passo na direção da caracterização dessas formas de desenvolvimento do pensamento que propõem uma alternativa ao quadro estruturado pela epistemologia moderna.

\footnotetext{
31 "Parece-me que a intuição se comporta freqüentemente, na especulação, como o demônio de Sócrates na vida prática; é ao menos sob essa forma que começa, e sob esta forma também que ela continua a se manifestar de maneira mais nítida: ela proíbe. Diante de idéias aceitas habitualmente, diante de teses que pareceriam evidentes, de afirmações que até então haviam passado por científicas, ela sopra na orelha do filósofo: Impossível. (...) Força singular este poder intuitivo de negação! Como não atraiu mais a atenção dos historiadores da filosofia? Não é visível que o primeiro movimento do filósofo, quando seu pensamento ainda está mal assentado e ele não tem nada de definitivo em sua doutrina, é rejeitar certas coisas definitivamente? Mais tarde ele poderá variar em suas afirmações; jamais variará no que nega.” Bergson, H. 1950, p. 120.
} 


\section{DA ANÁLISE DA PERCEPÇÃO À METAFÍSICA DA MATÉRIA}

relação do corpo com o espírito

“O corpo, sempre orientado para a ação, tem por função essencial limitar, em vista da ação, a vida do espírito." ${ }^{1}$ Com esta afirmação, apresentada como a conclusão geral de sua análise do fenômeno da percepção e da relação entre o corpo e a alma, a partir do exemplo da memória, Bergson inicia uma investigação sobre a natureza da matéria. Com efeito, a defesa de sua hipótese de representação, tanto aquela que diz respeito à percepção quanto à memória, se funda na crítica à noção clássica de representação e, nesse sentido, na crítica à distinção de natureza entre representação e representado e à subsunção da representação à esfera da interioridade de um sujeito; ou porque, segundo a hipótese idealista, só teriam realidade o sujeito e suas representações; ou porque, segundo a hipótese realista, tais representações seriam o efeito da atuação direta — no caso da percepção — , ou indireta no caso da lembrança —, da matéria em geral sobre um corpo em particular, caracterizado como um mecanismo sensório-motor. Se, por um lado, a consequiência metafísica da hipótese idealista é, para Bergson, um imaterialismo, assumido ou não, a hipótese realista não teria como escapar do próprio materialismo. Isso porque, ao assumir que a atuação da matéria sobre o espírito se daria por meio do corpo, mais especificamente, por meio da alteração de partes do cérebro, onde, por sua vez, a representação da matéria seria produzida

\footnotetext{
${ }^{1}$ Bergson, H. 1999, p.199.
} 
e armazenada, tal posição acabaria, contraditoriamente, por reduzir a vida psicológica a um epifenômeno dessas atividades registradas nesse corpo.

No entanto, é pela própria aceitação da tese de que o corpo é um mecanismo sensório-motor que Bergson nega que esse corpo possa produzir qualquer representação da matéria. E será pela análise do fenômeno da percepção, comprovada pela análise do fenômeno da memória, que ele espera poder afirmar que a representação da matéria pressupõe uma realidade que vai além do papel exercido pelo corpo, o qual, reduzido ele mesmo ao estatuto de representado, teria sua ação limitada a de um centro de troca de influências e ações possíveis de serem detectadas nessa esfera. É, portanto, pela análise da percepção e da memória que Bergson acredita ter apontado para o estabelecimento de um outro dualismo que não aquele posto e, ao mesmo tempo, condenado, pelas teorias clássicas da representação.

Entretanto, ao retornar, agora no contexto da metafísica da matéria, à redução inicial do papel do corpo a um centro de ação e à conseqüente negação de sua capacidade de produzir representação, Bergson vai além e afirma que essa ação, da qual o corpo é núcleo, é limitante da vida do espírito. Retomemos então os termos em que o papel do corpo é descrito em uma e outra análise e vejamos de que forma tal limitação se exerce, e em que medida essa sua aplicabilidade ao espírito pode nos revelar algo sobre a realidade mesma desse espírito.

No caso da percepção, uma vez que se postula que o corpo, como instrumento de ação, não pode engendrar representações, mas apenas efetuar, a partir de suas possibilidades de ação, o recorte de um campo de imagens em um universo de imagens dado, tal ação 
limitante se dá, portanto, justamente como essa seleção, esse discernimento que, como já notou Bergson, indica a atuação do espírito. ${ }^{2}$

Pelo lugar que ocupa a todo instante no universo, nosso corpo marca as partes e os aspectos da matéria por nós apreciados: nossa percepção, que mede justamente nossa ação virtual sobre as coisas, limita-se, assim, aos objetos que influenciam atualmente os órgãos e preparam o movimento. ${ }^{3}$

Nesse sentido, a restrição do papel do corpo a um mecanismo sensório-motor que recebe influências do exterior e responde com ações, e o estabelecimento da relação entre essas ações e o discernimento, no campo de imagens, daquelas que seriam dadas na percepção, por um lado, limitam a apreensão da totalidade das imagens e, por outro, possibilitam a própria percepção. Isto porque uma hipotética percepção total equivaleria àquela percepção inconsciente de um ponto material qualquer que, "em sua instantaneidade, é infinitamente mais vasta e completa que a nossa, uma vez que esse ponto recolhe e transmite as ações de todos os pontos do mundo material". ${ }^{4}$ Portanto, é a estrutura sensóriomotora que Bergson chama de corpo-próprio que possibilita o recorte, a seleção, a limitação da totalidade das imagens, as quais então se tornam representação ao se destacarem como quadros percebidos atualmente (consciência de fato) de um todo potencialmente percebível (consciência de direito).

Por outro lado, se levarmos em conta que a consciência individual — aquela que efetivamente experienciamos — será constituída justamente a partir da permanência dessas imagens assim destacadas do todo, compreenderemos também como o corpo, instância a partir da qual essas imagens se destacam, de alguma forma limita a vida do espírito no sentido mesmo em que circunscreve sua experiência fundadora. Entretanto, se imagens são destacadas a partir da ação do corpo, é porque a ação, ou seja, a quebra das relações

\footnotetext{
${ }^{2}$ Bergson, H. 1999, p. 35.

${ }^{3}$ Bergson, H. 1999, p. 199.

${ }^{4}$ Bergson, H. 1999, p. 35.
} 
necessárias que ali se efetuam, assim o exige. Mas a quebra dessa necessidade inerente ao campo das imagens só ocorre porque observamos a vigência de um princípio de vida sobre essa matéria, organizando, inicialmente, uma parte dessa matéria que constitui o corpo do qual esse princípio se apropria. Isso porque esse princípio geral do qual proviria a alteração de uma ordem de interações a partir das quais nada de novo pudesse surgir, alteração chamada por Bergson de ação, só pode ganhar efetividade se tiver essa capacidade de alteração/ação limitada, e limitada por aquela porção desse mesmo universo a ser alterado que irá se constituir como centro mesmo dessa alteração. Portanto, o papel do corpo próprio revela seu caráter limitante em relação ao espírito, também nesse sentido, se considerarmos o espírito como aquele princípio vital e geral — não deduzível do universo da matéria inorgânica — que justamente preside a montagem dessas estruturas sensório-motoras com vistas à ação.

Se assim pudemos mapear a função limitante desse centro de ação que constitui o corpo vivo em relação à representação-percepção, o que podemos observar quanto à ação limitante do corpo quando se trata da representação-lembrança?

A definição dessa ação limitante, desenvolvida a partir da análise das relações entre a "memória e o cérebro" no segundo capítulo de Matéria e Memória (e que acabam por resultar em uma análise sobre as relações entre a "memória e o espírito", no terceiro capítulo), é resumida por Bergson da seguinte forma:

O papel do corpo não é o de armazenar lembranças, mas simplesmente de escolher, para levar à consciência distinta, pela eficácia que ele confere a ela, a lembrança útil, aquela que completará e esclarecerá a situação presente em vista da ação final. ${ }^{5}$

\footnotetext{
${ }^{5}$ Bergson, H. 1999, p. 199.
} 
Como mecanismo sensório-motor, se existe alguma retenção de experiências passadas - ou seja, algum tipo de memória - que possamos identificar no corpo vivo, esta só poderá se dar na forma mesma pelas quais essas ações são retidas ou executadas a partir desse mecanismo. O que, por outro lado, significa que a manutenção de imagens, que uma vez foram recortadas no universo das imagens - e a que também chamamos de memória - deve se efetuar de um modo independente desse mesmo mecanismo corpóreo. A partir disso, Bergson é levado a identificar dois tipos de memória distintos e independentes que, no entanto, como a análise da percepção e do reconhecimento demonstram, estão em constante relação.

A primeira, exemplificada por Bergson como aquela capacidade de memorizar um poema, se caracterizaria como uma ação, ou melhor, como a decomposição de uma ação vivida (as várias leituras que se seguem ao primeiro contato com o poema em vista de sua memorização), seguida da recomposição atual dessa ação (a execução do poema memorizado), o que implica a constituição de um hábito corpóreo justamente pela repetição contínua do esforço exigido nessa recomposição; repetição que, "como todo exercício habitual do corpo, é armazenad[a] em um mecanismo que emite uma impulsão inicial em um sistema fechado de movimentos que se sucedem em uma mesma ordem e ocupam um mesmo tempo". ${ }^{6}$ Trata-se, portanto, de uma memória que se caracteriza por uma disposição para agir determinada pelos mecanismos motores formados pelos movimentos que continuam as imagens que constantemente se alinham em um outro tipo de memória constituído, então, por representações.

Assim, ainda levando-se em conta o poema, esse segundo tipo de memória seria exemplificado pela lembrança de cada uma das leituras que foram feitas tendo em vista a memorização anteriormente citada (ou seja, aquela aquisição de um hábito pela repetição de

\footnotetext{
${ }^{6}$ Bergson, H. 1999, p. 84.
} 
um esforço). Não se trata mais de um mecanismo de ação, e sim de um modo de conservação de representações relacionadas a ações passadas. Aqui, nada remete à repetição, mas, ao contrário, à conservação de experiências vividas, as quais, apenas por terem se dado na duração inerente a essas experiências, já se distinguem umas das outras. E não se trata mais também do aspecto motor vivido nessa experiência, mas das imagens recortadas a contar dessa atividade motora e que, imediatamente após terem sido assim distinguidas do todo, foram mantidas na esfera individual da subjetividade que tem como base esta atividade motora. Cabe observar, ainda, que tal conservação estende-se a todas as imagens, sem nenhuma indicação de seleção que pudesse remeter ao princípio de utilidade prática da memória-hábito, mas por pura necessidade natural. ${ }^{7}$

Temos, portanto, de um lado, uma memória-hábito, que diz respeito à determinação de ações específicas a serem realizadas por determinados corpos no sentido de sua preservação. Sendo assim, é uma memória voltada para o futuro, ou para a melhor forma de determinar esse futuro, uma vez que a predeterminação da ação existe em vista da maior eficácia de ação de um corpo vivo interessado em se perpetuar:

\footnotetext{
nossa existência decorre entre objetos de número restrito, que passam mais ou menos frequentemente diante de nós. Cada um deles, ao mesmo tempo em que é percebido, provoca de nossa parte movimentos ao menos nascentes pelos quais nos adaptamos a eles. Esses movimentos, ao se repetirem, criam um mecanismo, passam ao estado de hábito e determinam em nós atitudes que se seguem automaticamente à percepção das coisas. Nosso sistema nervoso, dizíamos, não teria sido destinado a outro uso. Os nervos aferentes levam ao cérebro uma excitação que, depois de ter escolhido inteligentemente seu caminho, se transmite a mecanismos motores criados pela repetição. Assim se produz a reação apropriada, o equilíbrio com o meio, a adaptação, em uma palavra, que é o fim geral da vida. $^{8}$
}

\footnotetext{
${ }^{7}$ Cf. Bergson, H. 1999, p. 86.

${ }^{8}$ Bergson, H. 1999, p. 89.
} 
E, de outro lado, há a memória-representação, feita de passado, que ela conserva, sem qualquer pressuposto de utilidade, visto que mantém todas as imagens vividas, indiscriminadamente. "Esta retém a imagem das situações pelas quais ela passou, parte por parte, e as alinha na ordem em que se sucederam." ${ }^{\circ}$ No entanto, ao se afirmar essa conservação de todas as representações vividas independente desse corpo, surge como conseqüência a questão prática sobre a relação entre essas imagens assim conservadas e as imagens atualmente percebidas pela constante atuação do corpo, ou sobre como efetivamente se daria essa conservação do passado em sua regulação com o presente. Pois, como se poderia evitar a sobreposição de umas às outras, dado que o passado, conservado em sua inteireza, é, em termos de imagem, muito mais volumoso que o presente, ou, nas palavras de Bergson, "ao se conservarem na memória, ao se reproduzirem na consciência" tais imagens não iriam "desnaturar o caráter prático da vida, misturando o sonho à realidade?".

Parece ser o que ocorreria, se o corpo vivo, interessado sempre em sua sobrevivência e, nesse sentido, voltado sempre para o campo de imagens que se estende ao seu redor, não tivesse a capacidade de constantemente relegar tais imagens, que vão se formando por sua ação, para uma zona de inconsciência, em vista de novas ações e de novas imagens. Zona de inconsciência - denominada por Bergson de memória pura — onde as representações passadas permanecem, embora necessariamente indistintas, e de onde voltam a se distinguir, i.e., voltam a ser imagens, na medida mesma de sua utilidade, quebrando o obstáculo imposto pela ação, sempre que as afecções que uma vez a elas antecederam, com

\footnotetext{
${ }^{9}$ Bergson, H., 1999, p. 94.
} 
todas as possibilidades de ação que então se desenharam, se apresentem novamente, pelo que, então, elas poderiam aclarar a ação presente. ${ }^{10}$

Com efeito, enquanto os aparelhos motores se montam sob a influência das percepções cada vez melhor analisadas pelo corpo, nossa vida psicológica anterior está ali: ela sobrevive, — como procuraremos provar - com todos os detalhes de seus acontecimentos localizados no tempo. Incessantemente inibido pela consciência prática e útil do momento presente, quer dizer, pelo equilíbrio sensório-motor de um sistema nervoso tencionado entre a percepção e a ação, essa memória espera apenas que uma fissura se declare entre a impressão atual e o movimento concomitante para passar por ela suas imagens.

Sendo assim, se nossas representações se mantêm como lembranças, independentemente de mecanismos corpóreos, portanto, autônomas em relação ao próprio universo da matéria do qual elas se originaram, é justamente porque se constituem como essa memória pura, essa realidade que poderíamos considerar como parte daquilo que Bergson chamou de vida do espírito. Além disso, se os mecanismos corpóreos que se efetuam no presente são efetivamente os responsáveis pela inibição dessas representações retidas em uma zona de inconsciência, então a limitação da vida do espírito, no caso da memória, pela ação do corpo, estaria configurada.

Nesse momento, no entanto, não será preciso, para sustentar a manutenção dessas experiências vividas, como estados psíquicos independentes de qualquer mecanismo corpóreo, em um memória pura, negar que a consciência seja uma característica intrínseca a estados psíquicos?

Pois, do contrário, não estaríamos aqui, paradoxalmente, caracterizando como inconsciente justamente o domínio da representação, aquele mesmo da vida independente do espírito, que costumamos identificar à consciência pura?

\footnotetext{
${ }^{10}$ Idem, ibidem: "se nossa consciência atual, consciência que reflete justamente a exata adaptação de nosso sistema nervoso à situação presente, não descartasse todas as imagens passadas que não podem se coordenar com a percepção atual e formar com ela um conjunto útil".
} 
Mais uma vez será preciso nos lembrarmos de que não nos encontramos mais no universo da representação clássica, do interior do qual tal estranhamento se daria. E, nesse sentido, o próprio estranhamento é sinal de que Bergson teria conseguido romper de fato com esse universo, como ele se propõe.

Aqui, justamente o que não se pode dar é a distinção entre matéria e representação da matéria, por um lado, pela consciência, inerente à substância pensante na qual tal representação se daria e, por outro, pela inconsciência, inerente à substância extensa.

Ao contrário, o que existe, de um lado, é uma apreensão consciente da matéria que se efetiva pela ação real de uma parte dessa matéria sobre seu entorno. Ação que, por sua vez, pode ser reputada a um princípio que não se resume a essa matéria mas que nela se atualiza. De outro lado, a conservação das imagens então apreendidas, por não mais se distinguirem das anteriormente percebidas e também conservadas, assumem um estado que, paradoxalmente, somos obrigados a identificar a um estado de inconsciência. Conservação que, em última instância, teria também de ser reputada ao mesmo princípio de ação identificado na percepção consciente.

No entanto, como Bergson nos adverte, é apenas por termos identificado, segundo os parâmetros cartesianos, estados psicológicos à consciência, que não podemos compreender a existência de algo que se conserve de forma inconsciente e como estado psicológico. Assim como, por termos identificado a matéria a uma realidade que segue uma ordem por si mesma oculta à consciência, é que não poderíamos compreender sua existência como potencialmente consciente. Assim, para Bergson, essa existência, tanto dos estados psíquicos quanto dos objetos materiais, implica ao mesmo tempo, ainda que em graus diferentes, a apreensão consciente e a conexão regular. É apenas por que cada uma dessas realidades apresenta as duas características em graus diferentes que costumamos admitir 
que elas possuem apenas aquela característica que se apresenta em grau mais elevado. Com efeito, os estados psíquicos teriam a primeira condição satisfeita em maior grau uma vez que sua apresentação à consciência é perfeita porque total, condição que, por outro lado, seria menos satisfeita pela realidade da matéria em virtude da multiplicidade de elementos não percebidos pela consciência a qual, justamente, faria a ligação entre aquilo que percebemos e os demais objetos. Por outro lado, em razão mesmo dessa multiplicidade não percebida, a ordem entre os objetos levaria a uma relação necessária que seria negada aos estados psíquicos atuais uma vez que sua determinação, dada em grande parte pelo passado, é bastante mais contingente. Desse erro, segundo Bergson, freqüentemente cometido pela abordagem intelectualista, seguir-se-ia a "impossibilidade de dar aos objetos materiais existentes, mas não percebidos, a menor participação na consciência, e aos estados interiores não conscientes a menor participação na existência". ${ }^{11}$

No entanto, é pela própria observação das condições em que a consciência se apresenta que podemos observar tanto a existência de estados psíquicos inconscientes quanto o caráter consciente de partes da matéria. Pois se a consciência se apresenta quando há uma decisão a ser tomada ou uma ação a ser executada, é justamente quando um estado psíquico está, ao contrário daquele conservado inconsciente na memória pura, unido a um mecanismo sensório-motor, colado à matéria.

E, nesse sentido, consciência não mais se caracteriza como estado psíquico interior a um sujeito e inconsciência como matéria, mas consciência se caracteriza como estado presente, por oposição à inconsciência do passado guardado na memória pura e com o futuro de que é prenhe a matéria não atualmente percebida.

Pois o que configura a união entre um estado psíquico e um mecanismo sensóriomotor senão uma sensação unida a um movimento, ou seja, a caracterização mesma de

\footnotetext{
${ }^{11}$ Bergson, H. 1999, p. 164.
} 
Bergson de um presente que se torna consciente na percepção? Ora, para Bergson, o presente real, que necessariamente deve ter uma duração, está aquém daquele ponto matemático no qual os associacionistas o colocam, portanto, já no passado imediato, e também além dele, vetorizado na direção do futuro sobre o qual se efetivará uma ação. E, nesse sentido, "o passado imediato, enquanto percebido, é (...) sensação, uma vez que toda sensação traduz uma longa sucessão de excitações elementares; e o futuro imediato, enquanto se determina, é ação e movi mento. Meu presente é, portanto, ao mesmo tempo, sensação e movimento". 12

Sensação e movimento que estão ausentes naqueles estados psíquicos conservados na memória pura, uma vez que, ali, não mais inseridos na realidade da matéria, não mais podem receber ou executar movimentos — não mais são ativos — e, não mais submetidos à duração própria a esta realidade, perdem a distinção característica da imagem percebida, ou da sensação, assumindo a inconsciência da indistinção.

Assim, a partir da distinção, pela análise da memória, entre um hábito e a memória propriamente dita, aquela que diz respeito à conservação de experiências vividas, evidenciase a existência dessa instância de conservação de experiências — a memória pura totalmente independente da própria instância em que estas experiências se dão — a matéria e a consciência que a ela se cola. Independência que, por sua vez, denota uma distinção de natureza, uma ativa e sensível, a outra inativa e não-sensível. No entanto, como essa atividade e esse caráter sensível estão na origem mesma daquilo que é inativo e não sensível, há, ao lado dessa distinção radical, o caminho de uma continuidade.

Continuidade que se evidencia, tanto na passagem da percepção à lembrança, quanto da lembrança à percepção, quando então, convocadas por uma ação presente, estas lembranças pouco a pouco vão se distinguindo até, em estado de percepção distinta,

\footnotetext{
${ }^{12}$ Bergson, H. 1999, p. 153, grifo nosso.
} 
tornarem-se novamente imagem, novamente ligadas a um corpo. Para sustentar a distinção entre uma memória pura e uma matéria dada na percepção, não é preciso seguir a verificação empírica da realidade desse movimento - que vai da lembrança pura para a percepção -, realizada pelas análises efetuadas por Bergson dos fenômenos do reconhecimento e da atenção.

Com efeito, será justamente pela análise, por um lado, do reconhecimento — quando uma experiência passada se associa a uma experiência presente — , que será possível observar como essa associação se dá, de início, de forma automática, levando-nos a confundir a lembrança com a percepção (trata-se, mais precisamente, do fenômeno do recobrimento apontado anteriormente). Fenômeno que, por outro lado, só será consciente quando, atentos para a imagem (necessariamente composta) da percepção concreta, pudermos compará-la com outras imagens de experiências passadas que continuarão afluindo na sua direção e constantemente compondo-a, circunscrevendo um círculo que só se quebrará quando nossa ação ou nossa atenção forem dirigidas para outros pontos do espaço. Trata-se, então, do reconhecimento com atenção.

Notemos apenas que, mantendo-nos no nível das hipóteses teóricas, uma vez que nosso interesse inicial era apenas o de explicitar como o corpo poderia, no caso da lembrança, limitar a vida do espírito com vistas à ação, ao explicitar esta atuação do corpo em relação à vida do espírito, no caso específico da memória, e, nesse sentido, ao explicitarse a distinção das duas instâncias da memória, àquela inscrita no corpo e identificada como uma ação, e aquela independente desse corpo e identificada como representação, Bergson parece nos dar uma das chaves para pensarmos a própria natureza da matéria em sua relação de oposição e união com o espírito. 
Pois, a partir da distinção entre memória-hábito e memória-representação que, por um lado, confirmou o papel do corpo restrito ao de um mecanismo de ação, e, por outro, possibilitou a distinção de uma esfera de representação independente desse mesmo corpo e, por conseguinte, da própria ação, se revela uma outra distinção ainda mais fundamental, "uma diferença profunda, de natureza", que diz respeito à diferença de duração pela qual Bergson procurará, daqui por diante, caracterizar a própria realidade do espírito e da matéria. Diferença que se traduziria no fato de que aquilo que diz respeito ao corpo e, portanto, à matéria, envolve uma ação que, por sua vez, por ser a medida mesma da interação entre "partes" dessa matéria, deve ocorrer em um tempo próprio a elas (imagens); tempo que, por outro lado, a representação pura não teria de respeitar. Diferença, enfim, que, considerando novamente o exemplo do poema memorizado, é explicitada por Bergson nos seguintes termos:

\footnotetext{
A lembrança de determinada leitura é uma representação, e uma representação somente; apresenta-se em uma intuição do espírito que eu posso, a meu bel prazer, alongar ou encurtar; eu lhe atribuo uma duração arbitrária: nada me impede de abarcá-la de uma só vez, como em um quadro. Ao contrário, a lembrança da lição aprendida, mesmo quando me limito a repetir tal lição interiormente, exige um tempo bem determinado, o mesmo que é necessário para desenvolver, um a um, ainda que na imaginação, todos os movimentos de articulação necessários: não se trata mais, portanto, de uma representação, mas de uma ação. ${ }^{13}$
}

Assim, aquilo que caracteriza uma ação no campo de imagens, no caso o funcionamento de uma memória-hábito, é a forte presença de uma certa temporalidade — aquela própria do campo das imagens - com a qual essa ação tem de se haver. E, se levarmos em conta que toda ação executada por um corpo vivo implica o exercício de um princípio ativo que se atualiza no campo de imagens, justamente a partir dessa imagem especial que constitui o corpo vivo, então, será por esse princípio ativo, que aponta para o

\footnotetext{
${ }^{13}$ Bergson, H. 1999, p. 85.
} 
espírito, que tal temporalidade deverá ser considerada. Sendo assim, os movimentos a serem executados pelo corpo, ainda que sejam animados por esse princípio ativo, devem seguir o ritmo ditado pela interação entre a duração pelo qual esse princípio atua e a duração própria ao campo de imagens, aquele mesmo necessário à articulação de cada uma das palavras ou dos fonemas que compõem o poema (tanto aquelas que compõem o mecanismo sensório-motor, se tais imagens forem exteriorizadas na forma de som, quanto aquelas que compõem as imagens sonoras não exteriorizadas). Temporalidade que impera, portanto, mesmo ao recitar o poema apenas usando as imagens produzidas no âmbito daquilo que seria considerado a "interioridade" de um sujeito, no âmbito da imaginação, uma vez que, mesmo então, todas as letras, de todas as palavras, terão de ser "pronunciadas" distintamente. Assim, ao recitar o poema "interiormente", ou seja, sem causar modificações nas imagens circundantes com a produção de sons, ainda assim eu estaria agindo, e esta ação se configuraria como tal justamente porque ela implicaria certo tempo para ser executada, certa duração imposta pelas imagens. Sentido mesmo pelo qual ela se diferenciaria da representação, também “interior”, no âmbito da qual eu não estaria "lendo" o poema, mas me lembrando de uma leitura anteriormente executada sem, portanto, escandi-la em todos os seus momentos. ${ }^{14}$

Sendo assim, esse mesmo sentido, pelo qual se pode afirmar que a ação - que implica a percepção atual de uma imagem - e a representação pura se distinguem, acaba

\footnotetext{
${ }^{14}$ Nesse sentido, vemos como a noção de interioridade se distingue totalmente daquela cunhada pelas teorias clássicas da representação, e como exterioridade, interioridade, extenso e inextenso se confundem e se recompõem na forma da exterioridade expandida, de um lado, e da interioridade condensada, de outro. Assim, haveria, primeiro, a exterioridade do campo das imagens no qual estas estariam estendidas ao máximo, extensão que seria então uma vez contraída na medida da duração imposta pela atuação do princípio de vida a partir do corpo próprio, contraída novamente na medida da duração imposta pela conservação dessas imagens que se segue imediatamente à sua vivência e que se intensificaria na medida mesma em que essas vivências se afastassem do presente até perderem seu caráter de imagem, e assumirem o de representação pura, justamente por terem sido submetidas a um grau de contração tal pelo qual não mais se distinguissem umas das outras. Poderíamos supor, portanto, que, se tais imagens pudessem voltar a se distinguir tal qual no momento da percepção, ou seja, voltassem a adquirir aquele tipo de temporalidade que tinham quando foram destacadas da matéria, voltariam a ter materialidade e não mais seria possível distinguir a lembrança da percepção mesmo sem ter como correspondente a própria realidade material?
} 
também por trair uma continuidade na qual não é possível definir estritamente quando uma se transforma na outra. Pois se, mantendo-nos no exemplo de Bergson, ao me lembrar de uma leitura passada, posso impor um ritmo a essa lembrança, tornando-a mais longa ou mais curta e, por isso mesmo, representar-me mais ou menos indistintamente os momentos nos quais a leitura original se deu, é possível imaginar uma distensão total desses momentos, ao menos no limite daquela distensão pela qual se deu a leitura original. E o que seria a lembrança de uma experiência original pela distensão de todos os seus momentos a não ser a atualidade de uma nova experiência, em outras palavras, o que significa lembrarse de todas as partes componentes de uma leitura anterior do poema senão uma nova execução do poema? No entanto, é preciso cuidado para não confundir essa nova execução do poema - por uma possível lembrança absoluta de uma execução passada — com a execução do poema a contar de sua memorização.

Pois não podemos perder de vista que a memorização de um poema requer justamente o abandono das leituras anteriores e, se somos capazes de percorrer mais uma vez todas as partes de um poema sem mais considerar as experiências anteriores, é porque um mecanismo - pelo qual podemos recompor as ações passadas, em todas as suas articulações, automaticamente — foi construído. E é esse automatismo, que diz respeito a uma estrutura inconsciente (das imagens que formam o corpo) voltada para a ação e que, por sua vez, obriga a uma determinada submissão à temporalidade desse campo de imagens no qual essa ação se efetua, não implica, no entanto, a consciência das imagens dadas nessa temporalidade. Com efeito, podemos articular todas as palavras do poema, pelo que temos de respeitar uma certa duração, sem nos darmos conta de uma só das palavras assim articuladas. 
Articulação do passado com o presente totalmente distinta, portanto, daquelas lembranças que pouco a pouco se tornam conscientes no processo de rememoração atentiva.

\begin{abstract}
Trata-se de encontrar uma lembrança, de evocar um período de nossa história? Temos consciência de um ato sui generis pelo qual nos destacamos do presente para nos colocar de início em um passado geral, depois em uma determinada região do passado (...). Mas então nossa lembrança permanece ainda em estado virtual; apenas nos dispomos a recebê-la adotando a atitude apropriada. Pouco a pouco ela aparecerá como um nebulosidade que se condensará; de virtual passa ao estado atual; e à medida que seus contornos se desenham e que sua superfície se colore, ela tende a imitar a percepção. Mas permanece ligada ao passado por raízes profundas, e se, uma vez realizada, não se ressentisse mais de sua virtualidade original, se não fosse mais, ao mesmo tempo que um estado presente, algo que corta o presente, jama is a reconheceríamos como uma lembrança. ${ }^{15}$
\end{abstract}

Com efeito, trata-se, aqui, da diferença existente entre a imagem que se torna consciente, na percepção, a partir da ação do corpo que desenha o esboço que ela preencherá, e, por um lado, o passado, região das lembranças puras, onde estas imagens existem em estado virtual, e, por outro lado, o próprio mecanismo corpóreo que evocará essas imagens.

Desse modo, no limite, as lembranças de experiências passadas só se mantêm enquanto lembrança em seu estado de indistinção, pois, à medida que vão sendo trazi das novamente à consciência, à medida que vão se distinguindo em imagens mais nítidas, vão, por esse mesmo movimento, se tornando cada vez mais ação e menos representação, acrescentando às cores antigas àquelas da temporalidade na qual estão se inserindo, até tornarem-se ação presente. Pois, como seria possível distinguir a lembrança de uma viagem a Paris de uma estadia atual em Paris, se eu pudesse trazer à consciência atual cada impressão então vivida, ou seja, se a mesma relação então estratificada entre a minha duração e a duração própria ao conjunto de imagens que então se me apresentaram fosse novamente configurada?

\footnotetext{
${ }^{15}$ Bergson, H. 1999, p. 148.
} 
Uma coisa, portanto, é a montagem de um mecanismo motor, pela repetição de experiências (no caso, a leitura repetida do poema) até que sejamos capazes de fazer esse mecanismo funcionar sozinho, de modo inconsciente; outra coisa seria nos colocarmos no passado de tal modo desvinculado do presente que pudéssemos revivê-lo no mesmo ritmo em que ele se deu como percepção presente - nesse caso não haveria mecanismo montado, e recitaríamos o poema porque seríamos capazes de reconstituir a própria consciência de todos os momentos então vividos —, possibilidade que só se efetuaria com o total desequilíbrio de uma personalidade que minasse o exercício de seu princípio vital e, só por isso, fosse capaz de imergir de modo tão absoluto no passado. Outra coisa, ainda, é aquilo que se dá comumente — ou seja, nos sujeitos cuja vida psíquica encontra-se minimamente em equilíbrio com o mecanismo sensório-motor correspondente — quando nem nos encontramos naquele presente absoluto no qual há apenas a atuação inconsciente de um mecanismo motor, nem, muito menos, sob a influência absoluta de um passado que revi veríamos em todos os seus detalhes, pelo que não mais poderíamos distingui-lo do presente, mas, sim, em um presente sensório-motor informado de passado, de modo que poderíamos tanto tender para uma quanto para outra direção. ${ }^{16}$

A partir dessas considerações, não só compreendemos como lembranças e percepções se distinguem (e, portanto, memória e matéria), e como se confundem na constante passagem de uma à outra, mas também que há sempre um caminho aberto pela percepção atual para que lembranças venham recobri-la. Pois basta, para tanto, que uma imagem anteriormente vivida e atualmente condensada com outras na forma de lembrança

\footnotetext{
${ }^{16}$ A esse respeito podemos nos remeter à caracterização, apresentada por Bergson, do homem de ação como um espírito equilibrado que se oporia tanto ao sonhador quanto ao impulsivo: “ O que caracteriza o homem de ação é a prontidão com a qual ele convoca em ajuda a uma determinada situação todas as lembranças que com ela se relacionam; mas é também a barreira intransponível que se encontra no limiar de sua consciência, às lembranças inúteis ou indiferentes. Viver no puro presente, responder a uma excitação por uma reação imediata que a prolonga, é próprio de um animal inferior: o homem que procede assim é um impulsivo. Mas não está melhor adaptado à ação aquele que vive no passado pelo prazer de ali viver, e para o qual as lembranças emergem à luz da consciência sem proveito para a situação atual: este não é mais um impulsivo, mas um sonhador."
} 
encontre uma brecha pela repetição daqueles elementos motores a partir dos quais uma vez ela se configurou, para que ela volte a se distender e recobrir o esboço desenhado por esses mesmos elementos motores.

Além disso, se é possível conceber um movimento pelo qual a (lembrança) representação, ao se estender em todos os seus elementos, se desenvolve em (lembrança)ação, e se esta implica um mecanismo motor que re-insere aquela no campo material das imagens, é possível também conceber o movimento inverso. Movimento pelo qual, justamente, as imagens que acabaram de ser distinguidas na percepção vão se mesclando nas anteriormente recortadas num processo ininterrupto de conservação, por acumulação e contração, que acaba na indistinção total da lembrança-pura, fonte de toda lembrançaimagem. Movimento regido agora pela temporalidade daquele princípio ativo que, desde sua atuação na contração da imagem recortada na percepção, vai impondo seu ritmo de forma cada vez mais eficiente pela contração cada vez maior dessas percepções-imagens em lembranças-imagens até a contração máxima — ou imposição absoluta de seu ritmo de duração - na lembrança-pura, ao mesmo tempo em que constrói aquele campo subjetivo, que, como um cone invertido cujo vértice se apóia no universo das imagens, comporia a vida do espírito.

Desse modo, pela análise do fenômeno daquilo que costumamos chamar de memória, encontramos, de um lado, a percepção distinta de imagens associada a uma ação habitual inscrita em um mecanismo motor e, de outro lado, a conservação indistinta dessas imagens como lembrança-pura de forma totalmente independente de qualquer corpo. De um lado, fenômenos inscritos em um campo de imagens, de outro, fenômenos que apontam para uma atividade autônoma, que se efetiva nesse campo de imagens, mas se destaca dele ao conservar, de modo independente, representações. De um lado a inserção na matéria, de 
outro, a atuação do espírito e, entre ambos, um caminho que configura sua possibilidade de união.

sob o ponto de vista da consciência

No âmbito de sua epistemologia, Bergson procurou defender, contra o materialismo — que ele acredita ser uma decorrência necessária do realismo —, que a percepção "extrapola infinitamente o estado cerebral" e, contra o idealismo - e sua corrente espiritualista —, que "a matéria transborda por todos os lados a representação que temos dela". No entanto, a partir mesmo da conclusão acima exposta a qual ele afirma ter chegado, ou seja, da afirmação do papel do corpo como limitador/ordenador da vida do espírito com vistas à ação, parece-nos que tal análise estaria mais voltada à refutação do realismo/materialismo, do que a do próprio idealismo/espiritualismo. Isto porque o diálogo sobre as possíveis funções do corpo descarta desde o início a posição que entende o corpo como simples representação, e se trava entre, por um lado, a posição (realista/materialista) que afirma que o corpo, como coisa, faz parte daquela realidade que se assenta em si mesma e que possui virtualidades - como a de produzir representação - veladas à percepção e, por outro lado, a posição de Bergson, que afirma que o corpo, como imagem, assenta-se em si mesmo mas de modo transparente (diálogo, aliás, travado com uma psicofisiologia em franco desenvolvimento e que Bergson afirma ter sido o ponto de partida da investigação desenvolvida em Matéria e Memória). Criticado o realismo, nesses termos, a hipótese materialista também cairia por terra, uma vez que não seria possível explicar os fenômenos psíquicos como epifenômenos cerebrais, não seria também possível reduzir à vida psíquica à 
matéria. Mas e quanto ao espiritualismo (ou a redução de toda realidade à consciência) que, aparentemente, teria sido descartado com a desconsideração inicial do corpo como pura representação? Não teria ele voltado pela porta dos fundos?

É certo que a crítica ao idealismo esteve presente em toda a discussão epistemológica, no entanto, uma vez que, para além da tese em questão sobre o papel do corpo, propôs-se ainda, pela análise da percepção pura, a identidade de natureza entre a matéria e nossa representação da matéria e, pela análise da memória, a riqueza e a independência da atividade do espírito, parece ser preciso, ainda, uma investigação sobre a realidade da matéria para dar fundamento ontológico a isto que, do lado da matéria, "transborda por todos os lados" à sua representação e, nesse sentido, refutar também o espiritualismo - ao menos aquele ainda subsidiário da caracterização cartesiana de espírito.

Entretanto, a construção de uma metafísica da matéria — de que se trata agora parte da crítica às condições da percepção reveladas pela própria análise epistemológica realizada. Ou seja, ao desvelar o contexto da práxis no qual a percepção se insere — ação de uma parte da matéria sobre o seu entorno, resultando em um destacamento de uma parte desse entorno que se torna percepção consciente — revela-se também a inadequação de seus pressupostos para o contexto do conhecimento puro e as confusões nas quais esse conhecimento puro se enreda quando não se dá conta dessa inadequação. Sendo assim, se é por não ter levado em conta que a percepção consciente da matéria é uma experiência marcada pelo interesse em recortar zonas limitadas sobre as quais a ação de um corpo organizado possa se exercer — imobilizar e recortar objetos em um fluxo contínuo —, que tal experiência foi tomada como ponto de partida para o conhecimento da realidade, será pela crítica às condições inerentes a essa experiência que tanto os pressupostos sobre os quais a metafísica clássica se fundou, quanto os problemas deles decorrentes, se mostrarão 
falsos. Pressupostos que estariam implicados, segundo Bergson, tanto no idealismo quanto no realismo e, consequentemente, na concepção clássica de representação, ou de acesso do espírito à matéria. Pressupostos que se caracterizariam, de início, pela afirmação da unidade do espírito e da aparente multiplicidade da matéria, que seguiria pela afirmação da heterogeneidade de nossas percepções por oposição à homogeneidade infinitamente divisível e calculável na qual se resolveria a matéria subjacente a essas percepções, chegando, por fim, à oposição entre extensão e quantidade, de um lado, e inextensão e qualidade, de outro. Trata-se, portanto, da própria distinção entre espírito e matéria, segundo um ponto de vista que atribui a um o que é negado à outra, e que acabaria impossibilitando tanto o intercâmbio entre eles quanto, no final das contas, a manutenção de ambos, que não mais se sustentaria simplesmente pela admissão da inadequação das condições da prática à especulação teórica.

Restaria, no entanto, a partir da crítica à transposição inadequada das condições da percepção concreta para o âmbito da especulação, desenvolver os caminhos, indicados pela hipótese da percepção pura, de acesso direto à realidade da matéria. De um lado — uma vez que a percepção pura é afirmada como parte integrante da própria matéria, e que ganha assim, realidade objetiva —, revelar em que medida essa matéria não mais poderia ser entendida como a extensão geométrica do realismo, mas, em que medida, matéria e representação da matéria poderiam ser caracterizadas como extensão eminentemente qualitativa, hipótese que não poderia ser aceita pelo idealismo. De outro lado, uma vez que a conclusão decorrente da análise da teoria da memória pura - segundo braço da epistemologia bergsoniana - estabelece que a percepção concreta pressupõe a contração, pela memória, de inumeráveis "percepções puras" e, nesse sentido, que a heterogeneidade de nossas percepções se deve justamente a essa contração que se daria em um meio de 
heterogeneidade tão diluída que fosse para nós imperceptível, impõe-se que se proceda à investigação da pertinência em atribuir duração também à matéria, pelo que a heterogeneidade das qualidades sensíveis e a homogeneidade detectada pela ciência na matéria não implicariam uma distinção de natureza, mas uma diferença de graus, ou ainda, o encontro de duas realidades duracionais, matéria e memória, na percepção concreta.

No entanto, promover o embaçamento daquelas características que se acreditava fundamentais à experiência e a partir das quais tal experiência era partida em duas regiões que se colocavam uma diante da outra, sem nada em comum entre si, e com o desafio de interagirem; ou seja, promover as condições de identidade entre a percepção da matéria e a matéria, sem subsumir uma à outra, pelo que espírito e matéria se manteriam distintos ao mesmo tempo em que se possibilitaria seu contato, significa promover a matéria dada, por essa identidade, nessa experiência pura, ao estatuto de realidade absoluta?

É a própria validade do método intuitivo que então estaria colocado em questão. Validade que, acreditamos, se inscreve nesse mesmo movimento de crítica que não poderia ser encarado como um mero momento negativo do método que estivesse dissociado de um posterior movimento positivo de reconstrução. Pois, se é certo que o próprio Bergson assim distingue o método em uma parte negativa, "renunciar a certos hábitos de pensar e de perceber" ${ }^{17}$ e o que poderia então ser encarado como uma parte positiva, a de reconstrução da realidade, é certo também que "os elementos infinitamente pequenos que assim percebemos" e pelos quais essa realidade será construída, já são dados ao se obedecer às exigências do movimento crítico e, com eles, já é dado o acesso imediato à matéria. Isso porque, tal movimento crítico nos colocaria na própria fonte dessa experiência "acima dessa virada (tournant) decisiva na qual, curvando-se ao que nos é útil, ela se torna propriamente

\footnotetext{
${ }^{17}$ Bergson, H. 1999, p. 206.
} 
experiência humana." ${ }^{18}$ Sendo assim, o mesmo movimento pelo qual identificamos aquilo que determina nossa experiência no sentido da ação, nos revelaria a existência de uma realidade a qual poderíamos intuir "desfazendo o que nossas necessidades fizeram."

Mais uma vez, no entanto, não seria possível argumentar que, se é no próprio movimento crítico das condições de nossa experiência, e de sua transposição para a especulação pura, que poderíamos explicitar que a realidade a que temos acesso se mantém por si e se revela a nós, tal explicitação não se manteria no nível da argumentação teórica, portanto da linguagem, do entendimento que, colado à prática, deveria ser superado? Com que direito isto, que decorreria de uma crítica do entendimento, estruturada pelo próprio entendimento, poderia se arvorar a retorno ao imediato, conhecimento intuitivo, com a pressuposição do caráter absoluto que então lhe é outorgado?

Observemos, no entanto, que o próprio Bergson assume que se a aplicação do método intuitivo à matéria dependesse de nos libertarmos das condições fundamentais da experiência exterior, tal empreendimento seria uma quimera. E que se trata, portanto, de "saber se certas condições, que comumente consideramos como fundamentais, não diriam muito mais respeito ao uso que fazemos das coisas, ao partido prático a ser tirado delas, do que ao conhecimento puro que podemos ter dela". ${ }^{19}$

Se não se trata, portanto, de nos libertarmos de tais condições, mas de proceder à sua crítica e a de suas conseqüências teóricas, trata-se, no caso específico da matéria, de proceder à crítica à fragmentação dessa realidade em objetos com contornos distintos, — à moda das unidades da matemática — bem como à crítica à pressuposição, a partir dessa distinção, da realidade de uma espacialidade amorfa, infinitamente divisível, na qual o movimento só poderia ser considerado a partir da alteração da distância entre pontos fixos,

\footnotetext{
${ }^{18}$ Bergson, H. 1999, p. 205.

${ }^{19}$ Cf. Bergson, H. 1999, p. 208.
} 
realidade que seria então a própria essência da matéria que se estenderia sob a heterogeneidade de nossa experiência sensível; ou, ainda, trata-se de proceder à crítica ao espaço e ao tempo (e ao movimento por eles caracterizados) concebidos como forma necessária de nossa apreensão dessa heterogeneidade; e, assim fazendo, chegar àquela "massa confusa com tendência expansiva",20, para a qual o movimento, agora um "transporte de estados", passaria, de esquema espacial a ela aplicado, a caracterizar seu próprio ser em duração.

Portanto, ao dissociar a extensão do espaço, e o movimento do tempo espacializado, não somente superaríamos paradoxos teóricos, ou hábitos perceptivos, mas conheceríamos a própria realidade da matéria e compreenderíamos como nossa percepção, que é parte dessa matéria, coincide e se distingue dela.

Assim, a aplicação do método intuitivo à matéria, justamente por nos colocar naquilo que Bergson denominou 'tournant da experiência, quando usufruímos do nascimento da luz nascente que, aclarando a passagem do imediato ao útil, inicia a aurora de nossa experiência humana", poderia ser considerado segundo dois aspectos imbricados. De um lado, segundo seu caráter eminentemente crítico que, liberando a teoria de suas incongruências, revelaria um conhecimento imediato que, em sua coerência, se sustentaria por si mesmo. De outro, indicando que, se há um horizonte no qual um retorno ao imediato se inscreve, este não poderia ser acessado por uma experiência que estaria para além ou aquém da experiência humana, mas no aprofundamento desta. Caracterizado desse modo, o método intuitivo não deve ser considerado como um irracionalismo, deve se servir do entendimento e deve, ainda, almejar algo que o exercício estrito desse entendimento não poderia nos dar.

No entanto, nos interessa aqui que tal caracterização do método intuitivo nos leva a abordar pontos centrais ao pensamento de Bergson, a saber, a crítica à precedência do nada

\footnotetext{
${ }^{20}$ Idem, ibidem.
} 
a qual, ainda que tenha sido mais pormenorizadamente apresentada em Evolução Criadora, estaria implícita na crítica ao intelectualismo desenvolvida em Matéria e Memória (no que diz respeito à teoria da percepção, e, mais especificamente, no que diz respeito à caracterização do campo de imagens); bem como a questão da distinção e identidade entre percepção e percebido (no interior mesmo desde campo de imagens) implicadas nessa intuição ou percepção pura.

a crítica à precedência do nada - o ser como duração

Se, portanto, a caracterização do método intuitivo nos leva à crítica à existência é na medida mesmo em que se postula a pertinência da objeção de cunho idealista, pela qual a própria realidade disso que se teria alcançado pelo conhecimento imediato pudesse ser colocada em dúvida.

E a possibilidade de tal objeção não teria escapado a Bergson, uma vez que ele defende a validade do conhecimento a ser alcançado pela aplicação do método intuitivo à matéria no preâmbulo mesmo de sua aplicação. E ele o faz por uma rápida remissão à gênese da dúvida em relação ao conhecimento: “A própria idéia de duvidar", nos pergunta ele, "teria alguma vez surgido sem as dificuldades e as contradições que a reflexão aponta, sem os problemas que a filosofia põe?". E, nesse sentido, “se pudermos estabelecer que essas dificuldades, essas contradições, esses problemas nascem, sobretudo, da configuração simbólica que os recobre, configuração que se transforma para nós na própria realidade",21 não estaríamos então livres da dúvida e, portanto, diante de conhecimentos que teriam sua prova e justificação em si mesmos?

\footnotetext{
${ }^{21}$ Bergson, H. 1999, p. 209.
} 
Nesse sentido, parece que é para a própria necessidade de fundamentação da realidade, inerente à atitude teórica, que devemos nos voltar. Pois, uma vez dirimida a impossibilidade de aceitar o acesso à realidade de um fato, o que ainda nos levaria a duvidar desse fato, e, portanto, de sua forma de acesso? Ou, ainda, em que se assenta essa impossibilidade de aceitar uma realidade que se apresenta?

Portanto, da questão sobre a validade de nosso conhecimento somos inevitavelmente remetidos, nessas preliminares à aplicação do método intuitivo, à questão do Ser acessado nesse conhecimento.

Remissão que desejaremos desenvolver, inicialmente, pelo exame da crítica à precedência do nada, presente no cap. IV, de Evolução Criadora, a partir de uma passagem cujo conteúdo nos parece análogo ao da passagem acima citada de Matéria e Memória:

Se pudermos estabelecer que a idéia do nada, no sentido em que a entendemos quando a opomos a de existência, é uma pseudo-idéia, os problemas que ela levanta ao seu redor se tornarão pseudo-problemas. A hipótese de um absoluto que agiria livremente, que duraria eminentemente, nada mais teria de chocante. O caminho estaria aberto para uma filosofia mais próxima da intuição, e que não mais pediria os mesmos sacrifícios ao senso comum. ${ }^{22}$

E os sacrifícios que a filosofia — ao menos aquela que caracteriza a epistemologia moderna - pede ao senso comum, sabemos bem quais são. Ou ele deve renunciar àquilo que percebe, em nome de uma consciência individual que se opõe à uma matéria que se oculta por trás do que é dado nessa percepção; ou deve renunciar à subsistência dessa matéria, independente da percepção e, assim, problematizar qualquer relação do presente com o passado e o futuro, assumindo apenas a existência da percepção e do percipiente; ou, ainda, deve manter-se na pura empiria, pelo que se acredita que nada pode ser dito quanto à realidade de uma matéria e de uma consciência supostamente nela dadas.

\footnotetext{
${ }^{22}$ Bergson, H. 1948, p. 277.
} 
No entanto, não mais teríamos de negar realidade à percepção e àquele que percebe ou àquilo que é percebido, se pudéssemos provar que as dúvidas que podem então ser postas em relação a qualquer uma dessas instâncias se funda em um pseudo-problema, no caso, aquele proveniente da pseudo-idéia do nada. Nesse sentido, seria também o próprio movimento da crítica que nos revelaria a autenticidade do ser, tanto daquilo que se revela, quanto daquele para quem se revela e de sua própria revelação. Seria, portanto, no limiar da própria crítica que encontraríamos o fundamento para uma ontologia.

Voltaríamos, então, àquele estado imune às dúvidas quanto à realidade do ser, análogo ao do homem estranho às especulações filosóficas, caracterizado por Bergson, no prefácio à Matéria e Memória, homem que muito se admiraria se "lhe disséssemos que o objeto que ele tem diante de si, que ele vê e toca, só existe em ou para seu espírito" tanto quanto se lhe disséssemos "que o objeto é totalmente diferente daquilo que nele percebemos, que ele não tem nem a cor que o olho lhe atribui, nem a textura que a mão nele encontra." Para esse homem, com efeito, “o objeto existe nele mesmo e, de outro lado, o objeto é, em si mesmo, pitoresco como o percebemos."23

Mas, se a filosofia é caracterizada pelo rompimento com o senso comum, não é justamente porque essa posição ora explicitada é insustentável? O que então Bergson estaria propondo? Que evitemos os paradoxos da teoria e nos mantenhamos nos paradoxos da atitude ingênua do senso comum?

No entanto, em que consistiriam, precisamente, esses paradoxos? De fato, uma vez que Bergson se remeteu justamente ao senso comum ao formular sua concepção de matéria, é porque ele pretendia enfatizar que, também para ele, quando percebemos, estamos imersos na realidade, e que, no entanto, esta realidade extrapola nossa percepção dela. Nesse sentido, se há algum paradoxo na posição assumida pelo senso comum, este deve se

\footnotetext{
${ }^{23}$ Bergson, H. 1999, p. 2.
} 
encontrar na impossibilidade mesma de manter suas convicções. Impossibilidade que, para Bergson, só poderia existir porque este considera a heterogeneidade da experiência dessa realidade como fundamental, e não relativa às próprias condições dessa experiência, o que o levaria a assumir posições já eminentemente filosóficas. Sendo assim, para Bergson, se há incongruências no senso comum é porque ele já se desnaturou em filosofia, e procura superar a descontinuidade da experiência sensível costurando-as, à maneira dos realistas ou idealistas, por sobre um forro feito ou de espaço ou de espírito. Portanto, Bergson não parece nos propor que nos mantenhamos na ingenuidade do senso-comum, mas que a superemos de uma outra forma. Com efeito, Bergson entende ser necessário, para fundamentar a própria crença do senso comum no acesso que temos, pela experiência sensível, a uma realidade que, no entanto, excede essa própria experiência, questionar se sua heterogeneidade lhe é irredutível, ou se tal heterogeneidade não se deve, justamente, às próprias condições em que sua experiência, voltada para a prática, se dá.

Estaríamos, então, aparentemente, de volta ao contexto da crítica às condições da experiência do qual saímos. No entanto, a remissão à idéia do nada nos traz um novo elemento que nos revela que, ao negarmos, em um esforço teórico, a realidade daquilo que se mostra fonte de incoerência, buscamos como abrigo um ser positivo, uno, intemporal, no qual, apenas, acreditaríamos estar seguros. E esse é o ponto destacado por Bergson. Seguros contra o quê? Justamente contra a possibilidade da precedência do nada. Precedência do nada que já seria suposta no nível da ação, mas que, duplicada no nível teórico, se transformaria na mola mestra da relativi zação da percepção, tanto quanto da rejeição em considerar o percebido como duração.

No nível da prática, o nada seria aquela ausência de uma determinada ordem, ou de determinados objetos dos quais teríamos necessidade para agir. "Toda ação visa a obter um 
objeto do qual nos sentimos privados, ou a criar algo que ainda não existe. Nesse sentido bastante particular, ela preenche um vazio e vai do vazio ao pleno, de uma ausência a uma presença, do irreal ao real." Ou seja, a própria possibilidade de ação se funda no estabelecimento de relações de utilidade, na construção de objetos nos quais essa ação possa se exercer e, nesse sentido, ao ter de criar essa utilidade, antes que ela seja criada, o agente parece ir de um vazio a um pleno. Mas "a bem dizer, o nada de que se trata aqui não é tanto a ausência de uma coisa quando de uma utilidade." Os vazios, portanto, não existem realmente, pois são vazios relativos a uma necessidade daquele que age. Trata-se, antes, de uma ausência do que se procura, não de uma ausência absoluta.

No entanto, continua Bergson, “nossa especulação não pode se impedir de fazer o mesmo, e passa naturalmente do sentido relativo para o absoluto, uma vez que se exerce sobre as coisas mesmas e não mais sobre a utilidade que elas tem para nós." E, assim fazendo, postula a existência do único ser que, a seu ver, seria capaz de resistir a essa anterioridade - que lhe parece de direito - do nada. Concebe assim o ser eterno e imutável que só a matemática ou a lógica pode lhe dar. Com efeito, ninguém jamais se perguntaria pela fundamentação do princípio de identidade ou da lei de construção de um círculo. Tais princípios e leis parecem ter sua validade em si mesmos, e existirem desde sempre. No entanto, se o ser é fundado pela lógica, dado pelo conceito, ele está, desde sempre, dissociado da experiência (portanto daqueles pressupostos do senso comum assumidos por Bergson). É assim que, ao transformar uma negatividade prática, dada na experiência, em uma negatividade absoluta, a teoria acabaria por negar a realidade da própria experiência, passando a ter de refundá-la por si mesma. Refundação que parece impraticável ao olhos de Bergson, donde sua investigação sobre suas origens, e consequentemente, sobre sua real necessidade. 
Trata-se, então, de explicitar as origens práticas e teóricas da suposição da precedência do nada. Pois, para Bergson, se nos perguntamos "por que existo", "por que o universo existe", "por que o ser e não o nada" é porque o vazio que inserimos na experiência das coisas, por necessidade prática, se transforma, ao pensarmos na realidade das coisas, em um nada absoluto diante do qual o ser teria de se impor. "A existência aparece-me como uma conquista sobre o nada", nos diz Bergson, e parece aos filósofos que tal "conquista" só poderia ser efetivada por um ser pousado sobre si mesmo desde sempre, ser cuja essência só poderia ser dada em um conceito purificado de qualquer temporalidade real ou espacialidade concreta que implicasse transformação; algo que, portanto, não fosse concebido como realidade psicológica ou física, mas que, à moda das matemáticas ou da lógica, fosse eterno e imutável. Com tais prerrogativas não é de estranhar que a metafísica tradicional não possa aceitar o ser proposto por Bergson como realidade que dura, uma vez que tal duração, diante de um nada absoluto que se impõe por si, não pareceria ser "suficientemente forte para vencer a inexistência e pôr-se a si mesma". Com efeito, se a duração só se sustenta nos corpos, ou nas consciências, e se eu recuo diante da realidade de corpos e consciências e me pergunto como puderam superar o nada para reconhecer-lhes o direito à existência, recuo também diante da realidade da duração. Não recuo, no entanto, diante da realidade do axioma lógico $\mathrm{A}=\mathrm{A}$; sua evidência me parece de tal força que, por ela, ele seria capaz de colocar-se a si mesmo "triunfando sobre o nada na eternidade". É, portanto, uma evidência desse tipo que a metafísica procura para fundar o ser, que só poderá ser encontrado fora das coisas — fora, portanto, dos corpos e das consciências —, em um conceito fechado em si mesmo.

Para Bergson tudo isso parece um rematado contrasenso, pois não vemos que, ao voltar às costas para as coisas, jamais poderemos reencontrá-las? Que o modelo de nosso 
conhecimento, o próprio princípio de identidade, é mais um princípio que rege nossa ação do que uma regra inerente à própria realidade? As coisas são idênticas a si mesmas porque precisamos distingui-las para agir sobre elas. E as distinções estritas implicadas nessa identificação funcionam muito bem na prática. No entanto, para que tal princípio seja afirmado em relação a essas mesmas coisas desvinculadas das condições de nossa ação sobre elas, será preciso desconsiderar essas mesmas coisas, uma vez que, justamente, livres das restrições temporais e espaciais que nossa ação impõe a elas, não há mais exterioridade recíproca, mas há transformação imanente. Se, então, nos negarmos a considerar a realidade das coisas em sua própria transformação e, portanto, insistirmos em uma identidade que se manteria subjacente a essa transformação, esta só poderá ser dada em um conceito eternamente dado que se desvincula desse devir no qual elas estão imersas. Aqui não há contemporização possível, ou o ser é identidade eterna fechada em si mesma, ou é duração aberta para as coisas. A ironia, no entanto, é que, se postulamos o princípio de identidade e, assim, retiramos a realidade do devir inerente às coisas, é justamente porque agimos sobre as coisas e nela colocamos o nada absoluto que então acreditamos superar pela positividade absoluta das essências lógicas; no entanto, parece que não nos damos conta do principal, ou seja, se agimos sobre as coisas, é porque estamos imersos em sua realidade.

A ação não poderia se mover no irreal. A respeito de um espírito nascido para especular ou para sonhar eu poderia admitir que ele permaneça exterior à realidade, que ele a deforme ou a transforme, talvez até que ele a crie, como criamos as figuras de homens e animais que nossa inteligência recorta nas nuvens que passam. Mas uma inteligência que tende para a ação que se realizará e para a reação que a ela se seguirá, tocando seu objeto para dele receber, a cada instante, a impressão móvel, é uma inteligência que toca algo de absoluto. Alguma vez pensaríamos em colocar em dúvida esse valor absoluto de nosso conhecimento se a filosofia não tivesse mostrado em que contradições tropeça, a que impasses chega? 
Assim, nos mais múltiplos contextos — acima, o da determinação dos limites do entendimento no seio de uma genealogia da vida — Bergson repisa esse círculo vicioso. Agimos porque estamos imersos na realidade. Para agirmos fazemos distinções no fluxo do ser, aplicando a esse fluxo categorias e princípios válidos para essa ação. A partir dessas necessidades legítimas nos enganamos duplamente quando tomamos essas distinções feitas para agir, e os princípios que as regem, como inerentes ao fundo da experiência e quando, então, negamos realidade a essa mesma experiência pela descontinuidade que nela implantamos.

Naquilo que nos interessa por ora, no entanto, trata-se de desvelar, dentre esses tropeços do intelecto, os mecanismos pelos quais ele forja a ilusão do nada, e, nesse sentido, evidenciar o caráter ilusório das questões sobre o ser que, ao mesmo tempo, nos impede de aceitar o ser como duração.

Caráter ilusório que se evidenciaria, portanto, na demonstração da impossibilidade mesma de imaginar ou conceber a idéia do nada.

Com efeito, observa Bergson, mesmo que me fosse possível "fechar" todos os meus sentidos para o que existe como exterior ao meu corpo, minhas sensações orgânicas permaneceriam, bem como minhas lembranças de percepções anteriores e a consciência de que nada mais há ao meu redor; no entanto, se eu conseguisse apagar até mesmo as sensações provindas de meu organismo e toda a minha memória, para que a imagem do nada me fosse dada pelo meu próprio aniquilamento, seria preciso que, concomitante a esse aniquilamento, uma outra consciência se formasse. "Assim, por mais que eu faça, sempre percebo algo, seja de fora, seja de dentro. Quando nada mais sei dos objetos exteriores, é que me refugiei na consciência que tenho de mim mesmo; se venho a abolir esse interior, 
sua abolição mesma, por sua vez, torna-se objeto para um eu imaginário que, desta ve z, percebe como um objeto exterior ao eu que desaparece." 24

No entanto, os limites da imaginação nunca foram mesmo muito considerados pelos filósofos. Pois se é pelo pensamento que justamente eles afirmam poder atingir a verdade, bastaria poder conceber o nada absoluto para ele se pôr. E aqui a menção de Bergson a Descartes é bastante ilustrativa. Pois não foi o próprio Descartes quem nos ensinou que da impossibilidade de imaginar um polígono de mil lados não se seguiria a impossibilidade de seu conceito? Bastaria, para tanto, que pudéssemos dar a regra de sua construção. Esse mesmo raciocínio, segundo Bergson, estaria por trás da afirmação da possibilidade de construir a idéia do nada. Da aniquilação de um objeto, se seguiria a possibilidade de aniquilação de todos, bastando, para tanto, que eu me representasse a totalidade dos objetos e a possibilidade de aniquilá-los, sucessivamente, um a um, até chegar à idéia do aniquilamento de todos, que corresponderia a idéia do nada. No entanto, essa lei de construção da idéia do nada não se sustenta, e sua explicitação o mostra, porque a coexistência dos elementos pelos quais se deseja que ela seja composta implica contradição.

Se não, vejamos. O que concebo realmente ao eliminar, ainda que em pensamento, um determinado objeto. Que esse objeto estava presente e que, ao se ausentar, instaura-se ali o nada. Obviamente, se considerarmos que esse objeto é exterior, uma coisa, tal nada teria de ser concebido apenas como a ausência daquele objeto que imediatamente é substituído por outro, uma vez que, "não há vazio absoluto na natureza". 25 No entanto, continua Bergson, mesmo que admitamos esse vazio, ele só pode ser concebido como um lugar delimitado pelos objetos que estão ao seu redor, lugar que, por si só, impossibilitaria a eliminação absoluta de tudo pois, para que seja concebido, é preciso que haja coisas que se

\footnotetext{
${ }^{24}$ Bergson, H. 2005, p. 302.

${ }^{25}$ Bergson, H. 2005, p. 304.
} 
constituam como seus limites. No entanto, o ponto principal a ser considerado aqui parece ser o fato de que há motivações, portanto, razões exteriores que determinam o próprio conceito de ausência e, consequentemente, sua identificação com o vazio e com o nada. Com efeito, é porque há a conservação da idéia do objeto por uma memória que somos capazes de sentir sua ausência que se caracterizaria, então, simplesmente, como uma quebra de expectativa. É, portanto, somente porque esperamos algo — e só esperamos algo porque somos capazes de nos livrar do ritmo absoluto do presente, porque trazemos conosco nosso passado, porque somos seres que duram - , que podemos ser frustrados em nossas expectativas e, nesse sentido, encontrar nada do que esperávamos e, assim, confundir esse nada relativo com o nada absoluto. Nesse sentido "um ser que não fosse dotado de memória, ou de previsão, nunca pronunciaria aqui as palavras "vazio" ou "nada"; simplesmente exprimiria aquilo que é e aquilo que percebe; ora aquilo que é ou aquilo que percebemos é a presença de uma coisa ou de uma outra, nunca a ausência do que quer que seja." 26

Sendo assim, aquilo que ocorre quando dizemos estar diante de uma ausência, não é uma percepção do nada, mas a percepção da presença de um objeto que não se esperava encontrar, colorida pela afecção da decepção proveniente da substituição do objeto que se esperava encontrar. Assim, o que fica da análise da idéia de nada, relativa aos objetos exteriores tomados individualmente, é a existência da idéia de uma substituição, aliada ao sentimento de uma preferência (que, no entanto, é contrariada, pela falta do objeto desta preferência, não pela falta de qualquer objeto), portanto, de um nada apenas parcial.

Parcialidade que também se confirma em relação a cada um dos estados de consciência, uma vez que, também em relação a eles, só é possível perceber presenças, e não ausências. "Experimento uma sensação ou uma emoção, concebo uma idéia, tomo uma resolução: minha consciência percebe esses fatos, que são, todos eles, presenças e não há

\footnotetext{
${ }^{26}$ Bergson, H. 2005, p. 305.
} 
momento no qual não me estejam presentes fatos desse gênero."27 E se é possível que eu conceba a interrupção desses fatos, é preciso que eu me conceba concebendo essa interrupção. Portanto, também a minha inteligência só poderia ir do pleno ao pleno, se não fosse a intervenção da memória e, com ela, da nostalgia do passado.

Sendo assim, se a idéia do nada se sustenta na possibilidade de ser construída a partir da soma das idéias parciais de aniquilamento de objetos, e se, por sua vez, o aniquilamento dos objetos é apenas uma idéia relativa, já que ela implica uma substituição indefinida e constante entre todos os objetos, uns pelos outros, segue-se que a idéia de aniquilamento, vazio ou nada absoluto é carente de sentido, ou, como Bergson desejava demonstrar, uma pseudo-idéia.

No entanto, sempre seria possível desqualificar tal análise por conta de seu afamado psicologismo, uma vez que a noção de aniquilamento ou ausência relaciona-se, em última instância, a substituições ocorridas no tempo ou no espaço, noções que, justamente, só poderiam se sustentar por si mesmas se a crítica à precedência do nada, que ora se propõe, por meio dessas mesmas noções, fosse efetivada.

Ocorre que, uma análise que se quisesse estritamente lógica, também não poderia fugir ao caráter relativo de tal noção, uma vez que, recorrendo agora à própria crítica do argumento ontológico, nos termos em que Kant a propôs, Bergson nos lembra que, se a idéia de um objeto A não se distingue da idéia da existência desse mesmo objeto A, seguese que a idéia de sua inexistência não pode ser formada pela eliminação da idéia de sua existência, pois, sendo esta inseparável da do objeto, retirar uma significaria não pensar idéia alguma e, não, pensar a idéia do nada. Sendo assim, a idéia da inexistência de um objeto só pode decorrer de um acréscimo que, necessariamente, tem de levar em conta tal objeto, ou sua existência, como se queira. "Representar-se o objeto A como inexistente,

\footnotetext{
${ }^{27}$ Bergson, H. 2005, p. 306.
} 
portanto, só pode consistir em acrescentar algo à idéia desse objeto: acrescenta-mo-lhe, com efeito, a idéia de uma exclusão desse objeto particular pela realidade geral.",28

Trata-se, portanto, ao se pensar a inexistência de um objeto, de expulsá-lo para o campo da idealidade, por oposição a um campo de realidade no qual ele não caberia. Campo de realidade que, nesse sentido, é imediatamente posto. "O ato pelo qual declaramos um objeto irreal, portanto, põe a existência do real em geral". ${ }^{29}$

No entanto, mesmo que para pensarmos a inexistência tivéssemos de inicialmente pensar um existente, sua inexistência não poderia ser suposta simplesmente pela aposição de um não a essa afirmação, à moda das proposições negativas? A substituição de tal existente por outro existente ou pela realidade em geral não seria arbitrária ou justamente o que se quer provar ao proceder à crítica à possibilidade da existência do nada ?

A resposta a tais questões seria negativa, uma vez que, observa Bergson, seria apenas a aparente simetria entre as proposições afirmativas e negativas que estaria por trás da suposição segundo a qual uma proposição negativa teria tanto valor objetivo quanto uma proposição afirmativa. Bergson procura demonstrar, então, que, se há uma simetria lógica entre esses dois tipos de proposições, essa simetria não se confirma sob o ponto de vista objetivo que, em suma, é o que daria significado a tais proposições.

Isto porque, se as proposições afirmativas são "atos completos do espírito" aos quais correspondem conteúdos objetivos, o mesmo não se daria com as proposições negativas, estas não teriam a capacidade de suscitar idéias que, então, se distinguiriam das anteriores apenas por serem idéias negativas. Com efeito, tanto nos juízos que afirmam a existência quanto aqueles que afirmam a conveniência entre um sujeito e seu atributo, há a implicação direta de um conteúdo objetivo, enquanto que os juízos negativos só encontram sua validade

\footnotetext{
${ }^{28}$ Bergson, H. 2005, p. 309.

${ }^{29}$ Bergson, H. 2005, p. 309.
} 
em um outro juízo afirmativo acrescido de um elemento extra-intelectual. Tal elemento extra-intelectual funciona como um impedimento da completude da intelecção, que levaria o sujeito dessa intelecção a permanecer na consideração da inadequação entre o juízo afirmativo ao qual ele se refere e a percepção atual, impedindo-o de atentar para a substituição dessa realidade e, consequentemente, para a necessidade de substituição da proposição que lhe seria correspondente.

Tomemos, por exemplo, a proposição "esta mesa é preta" e "esta mesa não é branca". Para além da simetria implicada no fato de uma proposição afirmar a conveniência entre um sujeito e um atributo e a outra afirmar a inconveniência entre ambos, tais proposições se distinguem pelo fato de a proposição negativa não ser um juízo, como o é a proposição afirmativa, que versa sobre um conteúdo objetivo dado — pois a percepção descrita não é a do branco ausente, e sim do preto presente — , mas um juízo que versa sobre um outro juízo com conteúdo positivo, a saber, a afirmação "a mesa é branca" que é colocada como possível por oposição à mesa preta realmente percebida. Nesse sentido, pela negação, não nos remetemos a nenhum conteúdo negativo passível de ser descrito. Pois, aqui, justamente o que não há é uma descrição, mas, sim, a distinção entre um possível e um real, acrescida da referência a um interlocutor que seria advertido sobre a inadequação entre a possibilidade implicada no juízo afirmativo por ele proferido e a realidade percebida, portanto, a remissão a um contexto social e a um interesse pedagógico.

Ao se desvelar, assim, a incapacidade de uma proposição negativa suscitar um conteúdo negativo objetivo, uma vez que ela se resolve em uma dupla afirmação — “afirma algo acerca de uma afirmação, que, esta sim, afirma algo acerca de um objeto",30 — põe-se, novamente, uma subjetividade que se destaca da positividade do presente. Com efeito, é preciso que aquele que nega seja dotado de memória, isto é, da capacidade de manter um

\footnotetext{
${ }^{30}$ Bergson, H. 2005, p. 312.
} 
passado para o qual ele possa voltar constantemente sua atenção, dando, assim, as costas para o presente. Só então verá, na substituição constante desse passado, uma ausência, um vazio e, portanto, será capaz de negar, ou seja, afirmar que aquele passado para o qual ele está voltado não mais existe, na sua constante substituição. Quando negamos, portanto, "constatamos a mudança, ou, mais geralmente, a substituição, como veria o trajeto do carro um viajante que olhasse para trás e só quisesse conhecer, em cada instante, o ponto no qual deixou de estar; ele sempre determinaria sua posição atual exclusivamente por referência àquela que acaba de deixar, em vez de exprimi-la em função de si mesma".31

Mas é preciso, ainda, que haja um interesse que dirija a atenção desse sujeito para esse passado e que, assim fazendo, ele só perceba a ausência decorrente de sua substituição, e não aquilo que o substitui.

Com efeito, se imaginarmos "um espírito que seguisse pura e simplesmente o fio da experiência, não haveria vazio, não haveria o nada, mesmo o nada parcial, não haveria negação possível." Por outro lado, se, ao abolirmos esse passado, abolíssemos também qualquer interesse ou afecção que denotasse uma nostalgia por ele, da mesma forma, só restaria "a realidade que flui e o conhecimento indefinidamente renovado de seu estado presente que ela imprime em nós."32

Assim, também em relação ao juízo existencial anteriormente analisado, haveria apenas uma simetria de forma entre o que afirma a existência de A e aquele que nega a existência de A. Uma vez que, à negação de existência não corresponderia à idéia de um vazio, mas, além de implicar ao menos a idéia de uma existência possível de A, implicaria também uma incompletude, e nesse sentido, remeteria a um elemento externo ao próprio

\footnotetext{
${ }^{31}$ Bergson, H. 2005, p. 318.

${ }^{32}$ Bergson, H. 2005, p. 319.
} 
juízo, ou seja, à sinalização da substituição de uma existência possível por uma existência real, para um interlocutor que, no entanto, só estaria interessado no possível substituído.

Assim, fica evidente que aquilo que caracteriza uma negação é a afirmação da inadequação de uma afirmação sobre um possível em relação a uma realidade presente, acrescido do interesse em se manter nesse possível substituído pelo presente. Sendo assim, tudo o que vai além da descrição de conteúdos positivos a serem descritos (caráter objetivo) — afirmações — diz respeito a interesses de um sujeito e, nesse sentido mesmo, extrapola o âmbito dessa realidade a ser descrita.

Desse modo, se a análise da negação se resolve na substituição de uma realidade por outra, e na ilusão proveniente do interesse em se manter naquilo que foi substituído em detrimento daquilo que substitui, ampliando essa negação para o conjunto de todos as coisas, não chegaremos à idéia do nada, mas ao contrário, à idéia de Tudo, acrescida justamente desse "movimento do espírito que salta indefinidamente de uma coisa a outra, que se recusa a se manter no lugar e concentra toda a sua atenção nessa recusa, sempre determinando sua posição atual apenas por referência àquela que acaba de deixar." ${ }^{\text {,3 }}$

Não há, portanto, oposição possível entre o nada e o tudo, uma ve z que um se resolve no outro, haveria apenas espaço para a oposição entre um nada relativo, caracterizado pela própria atividade do espírito e a realidade na qual essa atividade se instaura. Mas deixemos a exploração desse aspecto para logo adiante e concluamos retornando aquele pseudoproblema do qual saímos e que seria colocado pela pseudo-existência absoluta do nada face à qual um ser eternamente dado teria de se afirmar.

${ }^{33}$ Bergson, H. 2005, p. 320. 
Se a análise nos mostrou o caráter ilusório da idéia de nada absoluto, confirma-se a hipótese segundo a qual um nada relativo, com origem na prática - e que, portanto, só pode ser concebido nessa relação de um sujeito e seu objeto, não podendo, assim, ser dado como anterior a essa relação e, muito menos, como anterior a qualquer existência — foi indevidamente transportado para o campo teórico por uma decisão metafísica.

Afastada a necessidade de passar pelo nada para chegar ao ser, não mais se impõe a essência lógica ou matemática, não mais a concepção estática e intemporal pela qual tudo teria sido dado de uma só vez. O caminho está aberto para uma concepção do ser que prescinda de fundamentação, para uma realidade que se faz no tempo, não uma realidade dada de uma vez por todas, para um ser se fazendo. Afastada a necessidade da razão suficiente a causalidade eficiente toma seu assento nas próprias coisas:

\footnotetext{
é preciso acostumar-se a pensar o Ser diretamente, sem fazer um desvio, sem se endereçar primeiro ao fantasma de nada que se interpõe entre ele e nós. É preciso, aqui, procurar ver para ver e não mais para agir. Então, o Absoluto se revela muito perto de nós e, em certa medida, em nós. Ele é de essência psicológica, e não matemática ou lógica. Ele vive conosco. Como nós, mas, por certos lados, infinitamente mais concentrado e mais contraído sobre si mesmo, ele dura. ${ }^{34}$
}

É possível compreender então que os problemas teóricos levantados pela fragmentação da prática se resolvem, por um lado, pela consideração do estatuto adequado desse nível de experiência que, como Bergson parece indicar, para desvelar o absoluto, deve ser aprofundada e não superada. Assim, se, para agir, devo distinguir uma heterogeneidade qualitativa pela qual construo objetos, para que tal heterogeneidade possa pôr-se por si mesma, não é necessário imaginar um suporte fora dela - o que, aliás, seria um contrasenso - , uma identidade positiva retirada do tempo, mas, ao contrário, observar que o tempo está inserido nela, pelo que sua própria multiplicidade perdura na continuidade de

\footnotetext{
${ }^{34}$ Bergson, H. 2005, p. 322.
} 
sua constante transformação interior. Por outro lado, afastada a hipótese da precedência do nada, a questão sobre a fundamentação do ser se mostra uma pseudo-questão, e a apreensão, pela aplicação do método intuitivo, desse ser que é percebido na experiência sensível, como duração, se legitima.

crítica à pré-existência do possível - o ser como evolução

A questão que agora se impõe, no entanto, é a de se a própria realidade então revelada, não englobaria, nela mesma, a negatividade que ela não mais tem de superar para se afirmar enquanto tal.

Tal questão tem, aliás, a nosso ver, interpretação estabelecida na obra já citada de Bento Prado Jr. ${ }^{35}$ Gostaríamos, no entanto, de retomar os pontos ali desenvolvidos à luz das considerações de Renaud Barbaras ${ }^{36}$; mais especificamente, investigar em que medida se estabeleceria, no universo das imagens, uma distância que estaria no cerne mesmo da teoria da percepção pura; o que implicaria a intuição do ser pela possibilidade mesma desse ser permitir a instauração, em seu seio, dessa distância constitutiva da percepção, ou, se quiserem, da negatividade. $^{37}$

Com efeito, de que se tratava a crítica à existência do nada desenvolvida por Bergson, cujas linhas gerais acabamos de acompanhar, senão de nos colocar diante da presença do ser que foi tematizado, em Matéria a Memória, como campo de imagens, cujo acesso seria dado, inicialmente, por uma "percepção pura”?

\footnotetext{
${ }^{35}$ Prado Jr., B. Presença e Campo Transcendental, São Paulo, Edusp, 1989.

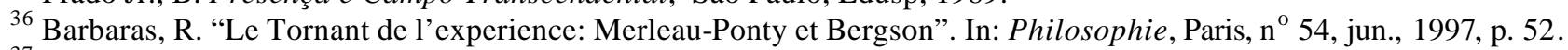

${ }^{37}$ Questões que, inspiradas na evolução da crítica de Merleau-Ponty ao pensamento de Bergson, abordaremos, aqui, apenas em segunda mão.
} 
Como vimos, tal presença, ou campo de imagens, se evidencia no mesmo movimento em que Bergson recupera a posição do senso comum que, desde sempre, se coloca instalado no ser, pela percepção, e pela admissão de que esse ser, no entanto, não se reduz a essa percepção. E Bergson justamente vai procurar recuperar tal posição, resguardando-se da ingenuidade a ela inerente, por colocar o ser em novas bases, ou seja, aquela anterior ao estabelecimento das condições pelas quais se dá a cisão entre sujeito e objeto. Negando o caráter original de tal cisão, Bergson completa sua crítica, estendendo-a à filosofia que, ao detectar a insuficiência da posição do senso comum, procura superá-la por uma reafirmação mais radical de tal cisão. Assim, surgiria a filosofia do cogito, pela qual toda a realidade teria de receber seu selo de validade por uma chancela da consciência que, como evidência primeira, se constituiria como ponto de partida radical a partir do qual tudo se sustentaria. No entanto, uma vez que, para Bergson, a filosofia erra de alvo ao detectar a insuficiência da posição do senso comum - ele não se equivocaria em instalar-se no ser, mas em fragmentá-lo — erra também no caminho que escolhe para corrigi-lo. Assim, aprofunda a fragmentação do real, da qual o senso comum parte, em cisão estrita entre duas regiões do ser; cisão pela qual a própria filosofia, como produto da consciência refletida, se aparta do ser e se torna, ao mesmo tempo, e por isso mesmo, único acesso privilegiado a este ser que deve, agora, ser refundado. Com efeito, na filosofia do cogito, não mais nos encontramos, pela experiência perceptiva, imersos no ser das coisas; mas, ao contrário, se é a consciência que pode alcançar a realidade que a ela se opõe, é porque ela é alçada à posição de consciência refletida, que possibilitaria o comércio entre o ser assim dividido em sujeito e objeto. É, portanto, a consciência que deve, em última instância, transcender à experiência do ser e outorgar-lhe realidade. 
No entanto, se pela critica à precedência do nada, não somos mais obrigados a abdicar da originalidade do ser em duração, é ele quem transcende a consciência, que se funda nele, como consciência perceptiva, assim como os objetos por ela percebidos.

Com efeito se, para Bergson, a superação da fragmentação da experiência ligada à pratica se dá pela crítica das condições dessa experiência, procurando revelar, ao contrário da tradição filosófica, o fundo real no qual essa experiência se dá, é possível, pela concepção desse fundo, como campo transcendental de imagens, ao mesmo tempo negar estatuto ontológico ao nada, e revelar que a sua instância é essa mesma da prática humana. Assim, "ao ser expulso do Ser, o Nada passava a constituir a estrutura da práxis e do modo humano de existência", pois "é o mesmo movimento que rouba à negação todo alcance ontológico que dá a ela a função de determinar a estrutura da subjetividade humana."38

No entanto, se a negatividade reside na percepção do ser, como objeto, por um sujeito e, nesse sentido, a percepção ocorre no próprio ser, então a negatividade não estaria agora instalada no ser? (O que fazer, então, com a crítica ao nada?)

Barbaras defenderá que assim é, e que Bergson não estaria alheio a esse fato, o qual, portanto, não entraria em contradição com sua crítica à metafísica nem, tampouco, com a postulação da intuição do ser (que, em última instância, estaria pressuposta em sua postulação do campo das imagens e em sua teoria da percepção pura).

Com efeito, é recuperando o que ele chama de "generalização da crítica do nada"39, efetuada por Merleau-Ponty, que poderíamos alcançar a exata dimensão das conseqüências dessa crítica e, portanto - para o que nos interessa aqui - do lugar ocupado pelo ser e pelo nada na filosofia de Bergson.

\footnotetext{
${ }^{38}$ Prado Jr., B. 1989, p. 215.

${ }^{39}$ Cf. Barbaras, R. 1997.
} 
Para Barbaras, haveria uma distinção de ênfase na crítica à metafísica desenvolvida pelos dois autores e não, estritamente, uma diferença de conteúdo. Se o objetivo de Bergson é o de desvelar a atitude metafísica que impossibilita a afirmação da realidade do devir, é a característica da imutabilidade do ser posto a partir do nada que ele, estrategicamente, destaca. Nesse sentido, uma vez negada a abordagem do ser a partir do nada, seria esse ser imutável e atemporal que seria negado, donde se seguiria a realidade do ser como duração. O que não significaria, no entanto, que Bergson não teria atentado para o ponto central da caracterização clássica de ser, (da qual a imutabilidade e a eternidade as quais ele se atém seriam apenas derivadas), a saber, sua positividade ou plenitude de determinação — evocada pela tradição justamente por parecer imprescindível na superação do nada concebido como precedente.

Pois não seria a própria realidade da duração, assim como Bergson nô-la propõe - e que pode ser encontrada, tanto na interioridade psicológica, quanto no campo transcendental das imagens —, e a doação dessa realidade — pela consciência de estados interiores e pela percepção - que, como vimos, calcada na crítica à possibilidade de existência do nada, apontaria para um outro sentido do ser e do nada? Outro sentido, pelo qual, nem o ser, como devir, permaneceria como substância, portanto, como positividade absoluta; nem o nada, agora interiorizado pelo ser, permaneceria como negação positiva dessa positividade.

Pois, se a duração, ou o tempo real, é, para Bergson, a própria realidade, é justamente porque o sentido do tempo real é esse novo sentido do ser. E se Bergson caracteriza o tempo como aquilo que "impede que tudo seja dado de uma vez", aquilo que, portanto, "retarda" que é "retardamento", "elaboração", "veículo de criação e de escolha", aquilo que "provaria que há indeterminação nas coisas", é porque entende a realidade, a partir mesmo da 
temporalidade que a caracteriza, como indeterminação. ${ }^{40}$ Nesse sentido, não haveria porque afirmar que o privilégio dado por Bergson à crítica ao aspecto intemporal do conceito clássico de ser o teria impedido de criticar justamente o que caracteriza esse ser como essência totalmente determinada. Para Bergson, a própria afirmação do ser como duração implica a afirmação do ser como indeterminação.

Tal consequiência direta se explicita na crítica feita por Bergson à pré-existência do possível ao real, que, aliás, seria análoga àquela estabelecida contra a precedência do nada ou, antes, a implicaria. Com efeito, a suposição de que a realidade está desde sempre dada em um conjunto de possibilidades ideais está no cerne da concepção da realidade determinada que substituiria o nada, e se opõe à concepção de realidade que, como duração é a própria "evolução contínua da imprevisível novidade". Ou, em outras palavras, a transposição, para a teoria, do hábito de ir do vazio ao pleno, que resulta na concepção da precedência do nada, e, consequentemente, na postulação de um ser dado como determinação absoluta, estaria implícita na desconsideração da "novidade radical" inscrita na realidade, que, por sua vez, resulta na consideração dessa realidade como um rearranjo de elementos pré-existentes regidos por leis imutáveis.

E, para Bergson, com efeito, desconsideramos a realidade movente e em constante evolução e, por isso, a resumimos ao sistema fechado de pontos materiais - calculáveis e, consequentemente, visíveis em seu estado presente - justamente porque não vemos que este sistema fechado é artificial, "extraído ou abstraído de um todo que compreende, além da matéria inerte e inorganizada, a organização." ${ }^{41}$

No entanto, se o método de conhecimento proposto por Bergson é, antes de tudo, a consideração daquilo que determina nossa experiência e, nesse sentido, nossa liberação das

\footnotetext{
${ }^{40} C f$. Bergson, H. 1950, "Le possible et le réel”, p. 102.

${ }^{41}$ Idem, ibidem.
} 
consequiências teóricas que justamente dão um caráter absoluto a essas condições, não seria também por esse método que poderíamos ver, entre estas condições, esta, a da abstração do mundo inorganizado do conjunto do mundo organizado? Com efeito, Bergson propõe:

\begin{abstract}
Tome o mundo concreto e completo, com a vida e a consciência que ele abarca; considere a natureza inteira, geradora de espécies novas com formas tão originais e tão novas como a de qualquer artista; entre essas espécies, observe os indivíduos, plantas e animais, cada qual com suas características próprias (...); para além desses homens, eleve-se até as sociedades que desenvolvem ações e situações comparáveis as de qualquer drama: como falar ainda de possíveis que precederiam sua própria realização? Como não ver que se o ocorrido sempre se explica, posteriormente, por determinados acontecimentos anteriores, um outro acontecimento totalmente diferente também seria adequadamente explicado, nas mesmas circunstâncias, pela escolha de outros antecedentes - que digo eu? Pelos mesmos antecedentes recortados de outra forma, distribuídos de outro modo, enfim, diferentemente percebidos pela atenção retrospectiva? De frente para trás se opera uma remodelagem constante do passado pelo presente, da causa pelo efeito. ${ }^{42}$
\end{abstract}

Ou seja, se advertidos pelo método bergsoniano, como não ver — ao olharmos para o conjunto da realidade, e não mais apenas para a sua materialidade — , a impossibilidade de deduzirmos a realidade futura daquilo que seria considerado o conjunto de suas possibilidades presentes?

É certo que a matéria nos parece repetição, que obedece a leis matemáticas e que é o próprio Bergson quem afirma que "uma inteligência sobre-humana, que conhecesse a posição, a direção e a velocidade de todos os átomos e de todos os elétrons do universo material em um momento dado, calcularia qualquer estado futuro desse universo, como fazemos para um eclipse solar ou da lua." ${ }^{43}$ No entanto, Bergson também nos adverte que, se tal determinação absoluta é valida para o mundo da matéria, "esse mundo é apenas uma abstração". E, antes do espanto, precisemos, abstração que não significa irrealidade, mas separação para efeitos práticos, daquilo que há de regular e estável no real, uma vez que a

\footnotetext{
${ }^{42}$ Bergson, H. 1950, "Le possible et le réel”, p. 114.

${ }^{43}$ Bergson, H. 1999, Prefácio.
} 
"realidade concreta compreende os seres vivos, conscientes, que estão inseridos na matéria inorgânica." 44

Com efeito, não seria possível considerar a realidade da matéria e da consciência sem considerar a anterioridade de uma em relação à outra, ou a matéria como o suporte préexistente no qual a consciência viria posteriormente se enquadrar? Ora, e não é justamente este todo o projeto de Bergson, desde o início?

Voltemos, então à Matéria e Memória, e à aplicação do método intuitivo à matéria, quando então ela se caracterizava como um fluxo de estímulos extremamente rápidos que se condensariam no ritmo das diferentes consciências, ganhando, assim, a heterogeneidade das diferentes formas de percepção sensível. E notemos como tal concepção se repete agora, quando Bergson, ao tratar da totalidade dos ser, abarca, nesse mesmo sentido, matéria e consciência.

\footnotetext{
Por que falar de uma matéria inerte na qual a vida e a consciência se inseririam como em um quadro? Com que direito colocamos o inerte antes? Os antigos haviam imaginado uma Alma do Mundo que asseguraria a continuidade de existência do universo material. Retirando dessa concepção o que ela tem de mítica, eu diria que o mundo inorgânico é uma série de repetições ou de quase-repetições infinitamente rápidas que se somam em mudanças visíveis e previsíveis. Eu as compararia às oscilações do pêndulo de um relógio: estas estão coladas ao vai-e-vem contínuo de uma mola que as une entre si e cujo progresso elas escandem; aquelas ritmam a vida dos seres conscientes e medem sua duração. ${ }^{45}$
}

Assim, a própria consideração do inerte pressupõe uma vida que comporta, no entanto, diferentes graus de atividade, que, como tal, só pode ser considerada como a imposição de um determinado ritmo e, nesse sentido, pela possibilidade de mensuração. Mas se há imposição de um ritmo, é porque há uma realidade que não se dá de uma vez por

\footnotetext{
${ }^{44}$ Idem, p. 100.

${ }^{45}$ Bergson, 1950, “Le possible et le réel”, p. 101.
} 
todas, mas que exige espera — que então pode ser ritmada — e que é signo mesmo de elaboração, de criação do novo.

"Mas a verdade é que a filosofia nunca admitiu sinceramente essa criação contínua de imprevisível novidade" totalmente determinado e dado de uma vez por todas, seja pela Idéia dos antigos, seja pela mathesis universalis que nos garante o alcance das leis pelas quais tudo é regido.

intuição do real

No entanto, se podemos compreender que o novo sentido de ser dado pela duração bergsoniana implica indeterminação, como compreender, ao mesmo tempo, que se possa apreender esse ser diretamente sob a forma da fusão ou coincidência proposta na percepção pura, que seria a forma da própria intuição da matéria?

Com efeito, voltando à análise proposta por Barbaras, uma das questões a ser levantada é justamente a de se Bergson poderia fugir de uma concepção essencialista do ser. uma vez que, justamente, ele concebe a apreensão desse ser como intuição, ou seja, como contato, fusão com as coisas, coincidência.

Poderíamos argumentar aqui que o vocabulário da coincidência, ou da fusão, é empregado por Bergson quando se trata da apreensão do ser a partir da interioridade da consciência. E, nesse sentido, as passagens, como a que se segue, são inúmeras:

A intuição da qual falamos diz respeito, antes de tudo, à duração interior. Ele apreende uma sucessão que não é justaposição, um crescimento pelo interior, o prolongamento ininterrupto do passado no presente que se apropria do futuro. É a visão direta do espírito pelo espírito. Nada mais se

${ }^{46}$ Idem, p. 115. 
interpõe; nenhuma refração através do prisma que tem como uma face o espaço e a outra a linguagem. No lugar de estados contíguos a estados, que se tornarão palavras justapostas a palavras, eis a continuidade indivisível e, por isso substancial, do fluxo da vida interior. Intuição significa, portanto, de início, consciência, mas consciência imediata, visão que se distingue com dificuldade do objeto visto, conhecimento que é contato e, mesmo, coincidência. ${ }^{47}$

Basta-nos, no entanto, observar que, nesse caso, a coincidência nada mais é do que o índice de sucesso de apreensão de uma realidade que se volta para o conhecimento de si mesma. Assim, o fluxo, ou a "perpétua eflorescência de novidade” que então é apreendido, seria simplesmente o resultado de se ter afastado aquilo que, do exterior, impediria tal experiência de um ser por si mesmo. No entanto, mesmo aqui, se a apreensão como coincidência parece, à primeira vista, ser menos problemática, ainda assim essa coincidência não pode ser entendida como totalidade. Uma consciência que conhece a si mesma não mais pela refração de seus estados no espaço, poderia conhecer, ou seja, estar consciente da totalidade que a compõe, nisso incluído o estado presente que constantemente se transforma em passado, tanto quanto todos os estados passados que subsistem como lembrança pura? Certamente essa consciência atua segundo uma evolução desse passado, ou ainda percebe aquele passado que recobre a percepção pelo qual ele se atualizou, no entanto, em um caso como no outro, ela só se apreende como esse fluxo que segue de um passado na direção de um futuro, porque sabe que há passado, e ela só sabe que há passado porque ele está à distância, porque não é apreendido à moda da coincidência total, porque, justamente, não há fusão, mas distanciamento, caso contrário, não haveria passado, mas eterno presente.

Não se daria o mesmo no caso do conhecimento do mundo material, ou, melhor dizendo, segundo as observações de Bergson anotadas acima, no caso da realidade concreta na qual não mais se dissocia a matéria de sua organicidade? Não haveria, também em relação à apreensão do mundo concreto, (ou da realidade revelada na percepção, e não

\footnotetext{
${ }^{47}$ Bergson, H. 1950.
} 
apenas na realidade revelada na capacidade de perceber) uma coincidência que implicasse parcialidade, distanciamento?

Pois, se a percepção caracteriza-se como apreensão da realidade nela mesma, é, em primeiro lugar, porque assumimos - esclarecidos pela crítica ao nada e ao ser essencial que a partir dele se postula — um ser que não se distingue de seu aparecer, ou porque assumimos a presença do ser percebido. Aquela mesma presença tematizada, no primeiro capítulo de Matéria e Memória, como imagem, imagem que se revela, para nós pela interpretação de Bento Prado Jr., como um campo transcendental que é condição do aparecer do ser e da consciência. E, considerando, então, a formulação desse campo de imagens transcendente, tal percepção só pode se constituir enquanto tal como uma coincidência que implique parcialidade, pois, do contrário, só haveria o ser e sua presença, mas não seu aparecer. É, portanto, justamente porque a percepção surge no seio desse campo e, nesse sentido, coincide com ele, que ela é necessariamente parcial. De resto, apenas uma apreensão que se coloca em um ponto de vista exterior ao que é apreendido, só, portanto, a apreensão do ser pelo conceito, pode se arrogar à totalidade, ainda que não tenha qualquer garantia de que essa totalidade percebida coincida em algum ponto com a realidade. Assim, a imagem, ao invés de propugnar a coincidência entre consciência e ser, coloca o ser percebido como real e transcendente, no seio do qual consciência e objeto se distinguirão.

No entanto, a parcialidade da coincidência — proposta na teoria da percepção pura — seria suficiente para caracterizar a distinção, no seio da presença, da consciência e seu objeto?

Se, pela percepção pura, Bergson funda a apreensão do ser por um recorte em sua presença, que a ela nada acrescentaria e, portanto, propõe, nesse recorte, uma colagem da 
consciência ao seu objeto, como, efetivamente, poderia se dar a iluminação dessa consciência e consequentemente desse objeto? Ou, nos termos em que Barbaras reproduz a crítica de Merleau-Ponty, tal coincidência do perceber e do percebido não comprometeria a própria experiência $^{48}$

No entanto, na própria postulação da coincidência entre percepção e percebido formulada na hipótese da percepção pura, Bergson já não assinalaria para o fato de que tal coincidência só se daria parcialmente, uma vez que a percepção pura ocorreria, como ele mesmo afirma, de direito e nunca de fato, portanto, nunca como experiência vivida? De fato, jamais há percepção sem contração da memória, por menor que ela seja, e, poderíamos acrescentar, sem afecção que, por si só, já macularia a pureza necessária para uma coincidência total.

Se, portanto, a hipótese da percepção pura é necessária para assinalar que há realidade dada na percepção, seu caráter ideal assinala, por outro lado, que essa realidade, que é então apreendida, o é, necessariamente, por mediação, pois toda apreensão inclui uma subjetividade - ou seja, uma trabalho da memória, um acréscimo de afecção — que promove a distinção, na coincidência, ou uma coincidência apenas parcial.

Para Barbaras, "somente compreendida desse modo a teoria bergsoniana da percepção parece estar de acordo com o estatuto ontológico da imagem e, em todo caso, com a crítica à metafísica."49

Com efeito, se abordar o ser sem a interposição do nada é assumir que o ser é idêntico ao seu aparecer, a percepção só pode ser entendida como um distanciamento em relação a esse ser. Um distanciamento que não pode ser suprimido, sob pena de dissolver-se a própria percepção, mas que aponta para um ponto de origem comum. Isto porque a

\footnotetext{
${ }^{48}$ Barbaras, R. 1997, p. 57.

${ }^{49}$ Barbaras, R. 1997, p. 58.
} 
coincidência tematizada pela percepção pura, remete àquele campo transcendental, aquela origem única do percebido e do perceber e, portanto, a uma indistinção de natureza, mas, ao mesmo tempo, a um écart irredutível entre o ser e sua apreensão, já que essa apreensão é esse mesmo écart que surge no ser; suprimido o écart, suprime-se a apreensão do ser, voltase à presença original do ser.

Assim, podemos concluir com Barbaras, "a crítica da metafísica leva Bergson a encontrar, no coração do Ser, uma negatividade que é condição de sua aparição, ou, sobretudo, que é a própria aparição enquanto coincidência parcial, diferença de idênticos."

Assim, ainda, o ser abordado sem a interposição do nada, não é o ser positivo dado em um conceito totalizante, mas aquele que apreendemos nele mesmo, ainda que parcialmente, na intuição. E, se a apreensão do ser, que nos dá o próprio ser, é duração, tal duração, mesmo apreendida como realidade psicológica, pode ser alçada à condição de absoluto. "Então o absoluto se revela muito perto de nós e, até certo ponto, em nós. Ele é de essência psicológica e não matemática ou lógica. Ele vive conosco. Como nós, mas, por certos lado, infinitamente mais concentrado e mais contraído sobre si mesmo, ele dura."50

Para tanto, é preciso voltar a considerar a caracterização dessa percepção como ação, assim como ela já havia sido apresentada em Matéria e Memória e, posteriormente, ao ser considerado na gênese da vida.

Com efeito, se a percepção não é contemplação, mas o distanciamento proveniente de uma ação que se inscreve no ser, é preciso considerar que essa inscrição faz parte da própria elaboração do ser em sua duração. Se há percepção pela ação que se inscreve no ser, é justamente porque esse ser não está pronto, acabado, mas porque ele evolui por meio dessas ações que nele se inscrevem. É nesse sentido que, acreditamos, a realidade material não se distingue da vida, e que a evolução desse misto constitui o ser em duração. Pois o que é a

\footnotetext{
${ }^{50}$ Bergson, H. 2005, p. 323.
} 
duração senão a continuidade de rupturas pelas quais o ser evolui e se constitui? E tal unidade ou continuidade da duração não pode ser encarado, como "um absoluto separado que se mediatizaria nas aparências, porque ela só se mantém enquanto tal, só realiza sua unidade graças às manifestações finitas: ela é portanto, mais o elemento no qual se realiza a identidade do absoluto e do finito. O ser bergsoniano [no qual a duração nos inicia] não é, portanto, um Ser positivo, de preexistência, do qual seríamos separados e diante do qual a coincidência seria por direito possível: ele só é ele mesmo mediante a indefinível renovação de suas negações finitas, que são, por isso, suas atualizações." ${ }^{21}$

Nesse sentido, afirmar que o absoluto é de "essência psicológica" é menos reduzir o absoluto à finitude ou positividade psicológica do que alçar o psicológico à apreensão do absoluto por sua atuação e, sendo assim, participação nele. Pela experiência psicológica, portanto, não há o enclausuramento do cogito, mas uma abertura para o mundo, pois, por ela, somos postos na duração que faz parte de nós e desse mundo.

É nesse sentido, ainda, que devemos entender o esforço em conhecer a realidade como o esforço em nos colocarmos naquilo que Bergson chama de "tournant da experiência, quando usufruímos da luz nascente que, esclarecendo a passagem do imediato ao útil, inicia a aurora da experiência humana." ${ }^{, 52}$

\footnotetext{
${ }^{51}$ Barbaras, R. 1997, p. 57.

52 Bergson, H. 1999, p. 206.
} 


\section{BIBLIOGRAFIA}

BERGSON, Henri. Essai sur les donées immédiates de la conscience. Paris, Quadrige/PUF, 1997.

. La Pensée et le Mouvant. Paris, PUF, 1950.

. Matière et Mémoire. Essai sur la relation du corps à l'esprit. Paris, Quadrige/PUF, 1999.

. L'Évolution Créatrice. Paris, PUF, 1948.

. Leçons de psychologie et de métaphysique. Paris, PUF, 1990.

. Bergson. Seleç. Franklin Leopoldo e Silva, trad. Franklin Leopoldo e Silva e Nathanael Caxeiro. São

Paulo, Abril Cultural, 1979 [col. Os Pensadores].

. A Evolução Criadora. Trad. Bento Prado Neto, São Paulo, Martins Fontes, 2005.

BARBARAS, R. “Le Tournant l'experience: Merleau-Ponty et Bergson”. In: Philosophie, nº 54, juin 1997.

BERKELEY, G The Works of George Berkeley Bishop of Cloyne, ed. e com. por A. A. Luce e T. E. Jessop, vols. I -III, 1949, Nelson ( Kraus Reprint), Nelden, 1979.

DeSCARTES, R. Méditations métaphysiques, $3^{\mathrm{e}}$ ed. Paris, Quadrige / Puf, 1992.

DELEUZE, Gilles. Bergsonisme. São Paulo, Ed. 34, 1999.

DELHOME, J. Vie et conscience de la vie; essai sur Bergson. Paris, Puf, 1954.

FOSTER, J. (ed.). Essays on Berkeley, Oxford, Clarendon Press, 1985.

.Berkeley on the Physical World", in Essays on Berkeley, Oxford, ed. John Foster and Howard Robinson, Clarendon Press, 1985.

Fussin, A. La perception chez Bergson e chez Merleau-Ponty. Paris, Société d'édition d'enseignement supérieur, 1967.

GUEROULT, M. Berkeley - Quatre études sur la perception et sur Dieu. Paris, Aubier, 1956.

GILSON, B. L'individualité dans la philosophie de Bergson. Paris, Vrin, 1978.

GOUHIER, H. G. Etienne Gilson, trois essai; Bergson, la philosophie chétienne, l'art. Paris, Vrin, 1993.

HEIDEGGER, M. Chemins qui ne mènent nulle part. Trad. Wolfgang Brokmeier. Paris, Gallimard, 1962.

HUDE, H. Bergson1. Paris, Editions Universitaires, 1989.

Bergson 2. Paris, Editions Universitaires, 1990. 
HuSSON, L. L’intelectualisme de Bergson. Paris, Puf, 1947.

JANKÉLÉVITCH,V. Henri Bergson. Paris, Puf, 1959.

JOHnStOn, G.A., The Development of Berkeley's Philosophy, London, Garland, 1988.

LE ROY, E. Une philosophie nouvelle, Henri Bergson. Paris, Alcan, 1913.

LUCE, A. A. The Dialectic of Immaterialism, London, 1963; “The Unity of Berkeley's Philosophy - a Reply”, Mind, vol 46, 1937.

______. "Berkeley's Existence in the Mind", Mind, vol. 50, 1940

NAULIN, P. "Le problème de la conscience et la notion d' 'image"”, in Bergson - Naissance d'une philosophie. Hude, H. et alii, Paris, Puf, 1990.

PAPPAS, G. S., «Berkeley immediate perception”, in Essays on the philosophy of George Berkeley, Boston, ed. Ernest Sosa, 1987.

_. "Ideas, Minds, and Berkeley", in American Philosophical Quarterly, vol. 17, n 3, July 1980.

PITCHER, G. "The objects of immediate Perception : Ideas of sense", in Berkeley, Routledge London, 1977.

\& Kegan Paul,

PrAdo JR, Bento. Presença e Campo Transcendental - Consciência e negatividade na filosofia de Bergson. São Paulo,

EDUSP, 1989.

RIDEAU, E. Les rapports de la matière et de l'esprit dans le bergsonisme. Paris, F.Alcan, 1932.

SILVA, Franklin L. Bergson: intuição e discurso filosófico. São Paulo, Ed. Loyola, 1994.

SoSA, E.(ed.). Essays on the Philosophy of George Berkeley, R.Reidel, Boston, 1987.

..Berkeley’s master stroke", in Essays on Berkeley, ed. John Foster and Howard Robinson, Clarendon Press, Oxford, 1985.

THIBAUDET, A. Le Bergsonisme 2v. Paris, NRF, 1926.

TIBERGHIEN, G.A. "Une source inconnue du bergsonisme”, in Bergson - Naissance d'une philosophie. Hude, H. et alii, Paris, Puf, 1990. 
TuRBAYNE, C.M. "Hume’s Influence on Berkeley”, in Revue internationale de Philosophie, No. 154, 1985 - fasc.3.

W Atson, R. A. "Berkeley in a Cartesian Context", in Revue internationale de Philosophie, dix-septième année, No. 65, 1963 - fasc.3.

WORMS, Frederic. Introduction à Matière et Mémoire de Bergson. Paris: PUF,1997. .La Conception bergsonnienne du temps". In: Philosophie, n 54, juin 1997. 